-

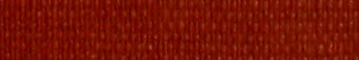




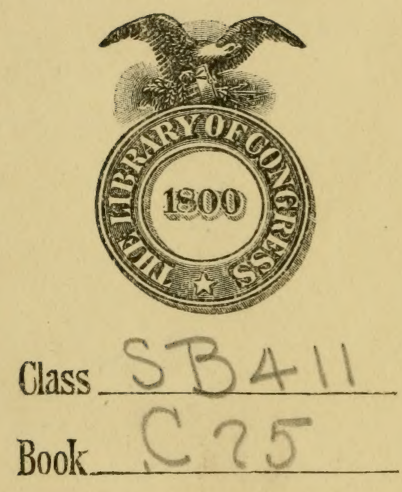

Copyright $\mathrm{N}^{\circ}$

CORYRIGHT DEPOST. 

, 




\section{HOW TO GROW ROSES}

DEDICATED TO THE

FLOWER-LOVING PEOPLE OF AMERICA

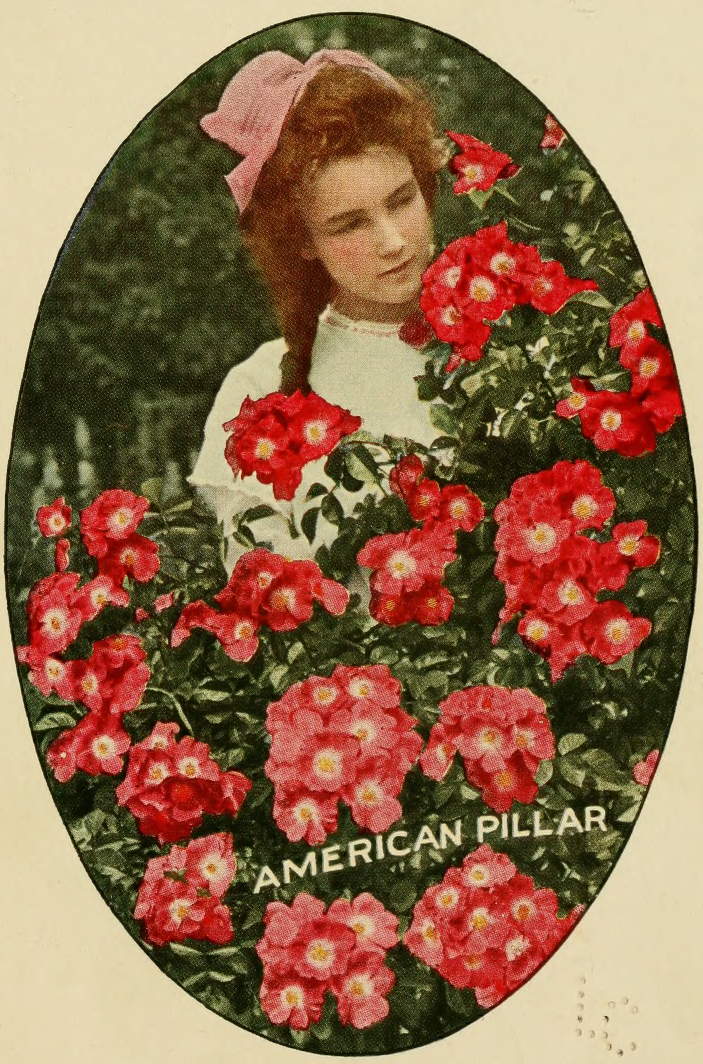

TWELFTH EDITION

REVISED AND ENLARGED

I9I6

THE CONARD \& JONES CO. WEST GROVE, PA. 


\section{Contents}

The Amateur's Rose-Garden . . . . . . . . . . . . . . 3

Establishing Ideals . . . . . . . . . . . . . . . . 5

The Rose-Lover's Calendar of Operations . . . . . . . . 6

Where to Plant Roses. . . . . . . . . . . . . . . . . . 9

Preparing to Grow Roses . . . . . . . . . . . . . . . I4

Drainage . . . . . . . . . . . . . . . I4

Soils ... . . . . . . . . . . . . . I5

Fertilizers . . . . . . . . . . . . . . . .

When to Plant . . . . . . . . . . . . . 17

Treatment on Arrival . . . . . . . . . . . . . . . 18

Planting . . . . . . . . . . . . . . . . . . 20

Staking the Roses . . . . . . . . . . . . . 22

Labeling . . . . . . . . . . . . . . . . . 22

Platting . . . . . . . . . . . . . 24

Mulching . . . . . . . . . . . . 25

Protecting the Roses . . . . . . . . . . . . . . 26

From Frost . . . . . . . . . . . . . . . . . . 26

From Enemies

PRUning . . . . . . . . . 31

How to Use This Pruning Information . . . . . . . . 34

Own Root, and Budded or Grafted Roses. . . . . . . 36

Selecting the Roses . . . . . . . . . . . . . . . . . . 37

Terms Used to Describe Appropriate Uses . . . . . . . . 4 I

One Hundred and Fifty-Eight Choice Roses . . . . . . . 43

Roses for Various Purposes and Uses . . . . . . . . . . 64

Selections for Special Sections of the United States of AMERICA

The Pacific Northwest

Minneapolis and Vicinity .

New York and Lower New England.

Roslyn and Northwest Long Island

Philadelphia and Vicinity .

Washington, D. C., and Points South

The South Atlantic and Gulf States

Chicago and the North.

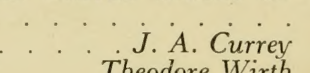

77

77

79

80 Admiral Aaron Ward 8I

82 Dr. W. Van Fleet 83

84

85

9I

92

The American Rose Society .

Rose Test-Gardens

C. Wintzer

W. C. Egan

The Increasing Regard for Roses.

Municipal Rose-Gardens

A Famous Rose-Garden . .

The Red Rose Church at Manheim

Rose-Beads

Attar of Roses. . . . . . . . . . . . . . . . . 102

HYbridizing. . . . . . . . . . . . . . . . . . . . . . . . . . 104

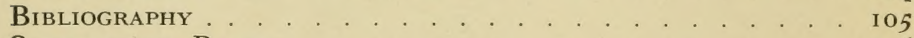

Synonymous Roses. . . . . . . . . . . . . . . . . . 106

Analysis of Species . . . . . . . . . . . . . . . . . . . . . 107

Roses Arranged in Classes. . . . . . . . . . . . . . . . i i o

INDEX . . . . . . . . . . . . . . . . . . II6 

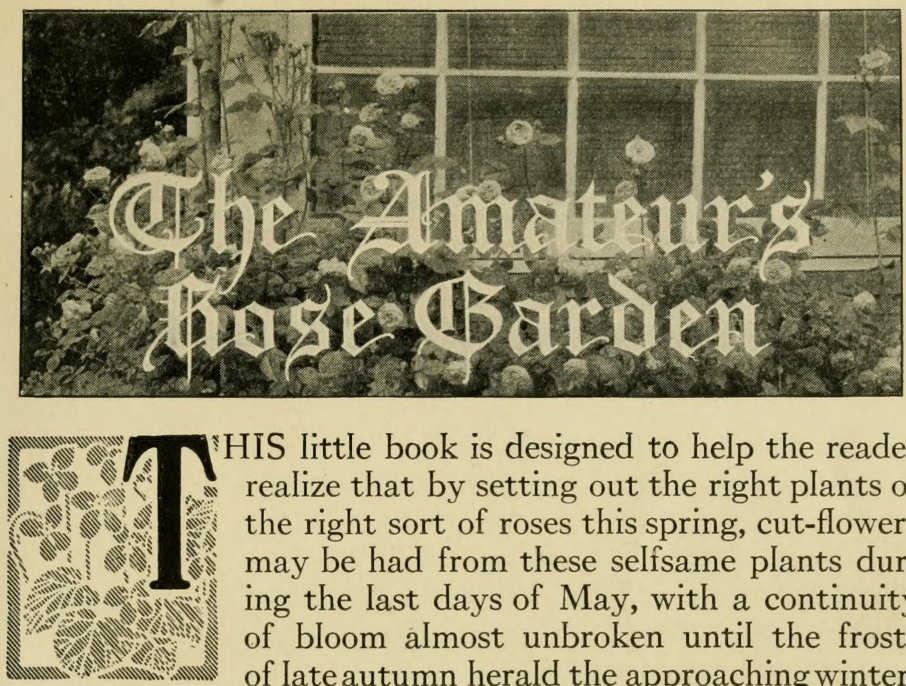

HîS little book is designed to help the reader realize that by setting out the right plants of the right sort of roses this spring, cut-flowers may be had from these selfsame plants during the last days of May, with a continuity of bloom almost unbroken until the frosts of Iate autumn herald the approaching winter.

Amateurs are now able to have an all-summer "feast of roses," as well as the skilled professional, and it is the amateur's rose-garden, especially, that we have had in mind when writing the following pages.

A large garden is not requisite. Two or three dozen good plants, of the modern and greatly improved sorts, properly selected, will give much enjoyment; while a garden of roses with somewhat greater variety and extent can readily be made a summer-long delight.

In spring, one can have the pleasure of building aircastles about the plants. When the warm days of June arrive, these air-castles will have taken substantial form, and you may go from one plant to another, giving each a little daily attention, contrasting one proud beauty with another equally queenly, and, best of all, gathering an abundance of lovely roses. Half an hour of such tonic-toil each day is a great nerve-restorer, and, what many of those who have tried it realize, it is also food for the soul.

Rose-growing among amateurs in this country is yet in its infancy. In England, before the war, nearly everyone grew roses. Dazzling vistas of roses were to be seen in the 
hedge-rows, along the country roads and lanes. Gardens were full of flowers, and each person seemed to be striving in friendly rivalry with his neighbor. Why was this extraordinary enthusiasm for the rose? Because it is without a peer among all the flowering plants. It presents nearly every floral shade, in combinations far more attractive than exotic orchids, and, above all, its delicious fragrance gives us the enjoyment of another sense-the crowning feature, in which no other flower can compete with it.

Since history was first written the rose has been associated with the most important events in the life of man. For centuries it has been fully recognized as the Queen of Flowers, honored alike by poet and king. Yet such varieties as Ophelia, Sunburst, and Frau Karl Druschki, the ancients never knew! Why, then, should not you and yours share in the pleasures of the twentieth-century roses, to your own enjoyment and to the advantage of those around you? Just a little garden of these modern well-bred roses; just a little daily, loving care; just a little cost; and the result to you and your neighbors will be the glory of the Queen of Flowers.

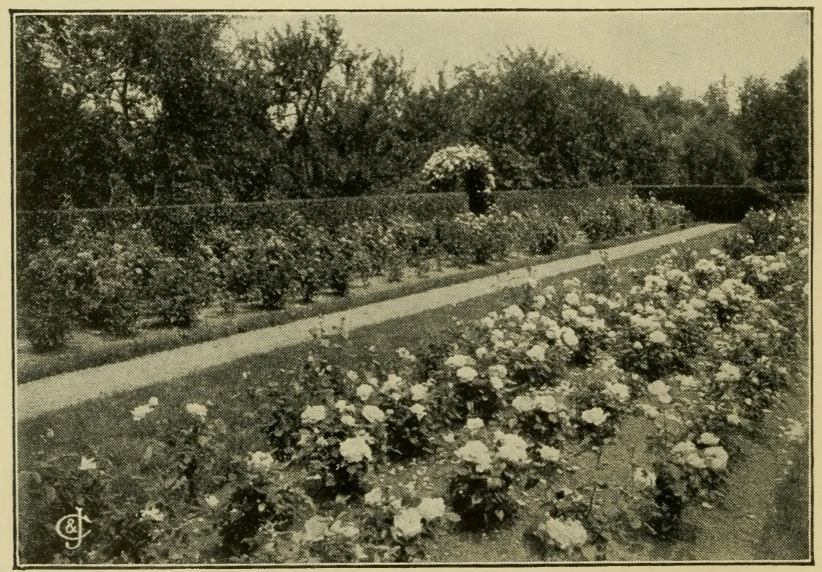

The Glory of the Queen of Flowers 


\section{Establishing Ideals}

First consider what kind of rose-garden you will plan. Roses seem to enjoy being arranged in countless ways. Will the first show of bloom to burst into view, as one approaches your home, be on your pergola, or arbor, or rose-covered summer-house? If none of these furnishes appropriate setting, probably your banks or fences will be clothed or beautified. A variety of types, shown on the following pages, is available, and choosing from these will become a delight.

Perhaps your fancy may picture prosperous beds, abounding in a wealth of bloom, to be seen across a sweep of level lawn, or from your favorite room in the house, or even hidden beyond the curve in your garden-walk.

The formal rose-garden, too, is important, especially on the larger place. There are excellent reasons why the rose-garden should have a domain all its own. These fastidious creatures that so well repay your thoughtful care may well be grouped and with greater resulting effectiveness. In no other case, perhaps, does careful planning pay so well as in the formal garden.

In these brief suggestions of rose-garden possibilities let us recall vividly the value of the rose in the landscape. Here again a knowledge of varieties is important. Landscape architects are recognizing more and more the noteworthy species which are valuable in mass-plantings for showy effects, for retaining embankments, for bordering driveways, or even for certain types of hedges.

Or you may wish most for a garden of roses from which to cut bouquets, so that "the Glory of the Garden" may be reflected in your home. "Good taste" will suggest the right roses-one for this vase, a bunch for that bowl, a spray for the guest-room, still others for the hallway or the diningroom table, then surely some for boutonnieres, and at times for "state occasions." Surely anyone who has experienced the exquisite thrill welling up in the soul from the presence of choice roses well arranged will be eager to develop the skill needed to make the best use of Nature's garden-gifts. 


\section{The Rose-Lover's Calendar of Operations}

These dates will be found relatively correct for the average season in the latitude of Philadelphia. If you live north or south, make the usual allowance of about four days for every roo miles of latitude. Comparative altitude must also be taken into consideration. The seasons vary; for example, the ground may be in good condition and ready for digging as much as three weeks earlier one year than it will be the following spring.

March 15.-Such hardy roses as are already planted should now be pruned.

March 25 to 30.-As soon as the ground can be well worked, plant new hardy roses which are to be had dormant. Prune these even more closely than older established bushes.

April 10.--Less hardy roses, including the Everblooming class, should be pruned. Begin to remove the winter protection as the increasing heat of the sun permits.

April 15.-Roses are not immune from mildew and other fungoid contagious diseases; therefore it pays at this time to spray with bordeaux mixture all your rose plants as well as nearby fruit trees and grape-vines.

April 25 to 30 .- Finish uncovering and pruning your roses. Plant new ones (now or until the middle of May). A slight shading of these from the sun will prove an advantage.

May I to 10 .-As soon as plants are well set with foliage, a spraying with rose nicotine or sulpho-tobacco soap will act as a preventive against aphides (green fly).

May 20.-As soon as buds begin to swell, weak manure-water may be applied to the plants. Spray again to kill off the aphides, otherwise they will multiply with amazing speed.

May 25.- Now starts the season's procession of bloom, led by the sturdy Rugosas and the Yellow Briar roses. Start feeding the Hybrid Perpetual roses with liquid manure.

June 1 .-With this month we see the true glory of the "Feast of Roses."

June 5.-Watch for the rose beetle and rose slug, and spray every ten days for three weeks with a half pound of arsenate of lead to ten gallons of water.

June 10.-Begin to nourish the Teas and Hybrid Teas with liquid manure. (Page 17.) You'Il soon see the result.

June 20 to 30.-Now the Teas, Hybrid Teas, and Climbers begin blooming in abundance. Cut your blossoms freely. Look out for mildew and apply the remedy.

July 1 . - Keep the soil well stirred. A dust mulch at this season is important. 
July 4.-Gather all the flowers you can; it is not best for the plants to have them die on the bushes. You should now be reaping a full harvest from the Teas, Hybrid Teas, etc.

July 10.-From now till autumn keep a sharp lookout for signs of fungoid troubles - such as (I) mildew, (2) black spot, or (3) yellow leaf, and apply bordeaux mixture. If any aphides appear, use rose nicotine.

July 15 . - Thin out the old canes and trim back all multifloras and other climbers noted under chapter on pruning.

July 20.- Now or earlier mulch your roses with grass-cuttings, old manure, leaves, sawdust, or peat-moss.

August 30.-Teas and Hybrid Teas bring forth their "Fall Flower Show." As soon as the buds form, remember that Bon Arbor or manurewater applied to the roots will help them to produce the blossoms you'II be proud of.

September 10 .-Some Hybrid Perpetuals bloom a second time.

October 15.-Make ready your new beds for next year.

November 15. - After the first frost, begin covering the stems of your roses, pages $2-6$, and, soon after this, complete the protecting of the more tender kinds.

Thanksgiving Day.-As soon as the ground has frozen, all should be safely nestled in their winter beds.

\section{WHEN YOUR ROSES ARE UNDER THE SNOW}

December.-Read Dean Hole's "The Book of Roses." (See Bibliography, page 105.)

January.- Send for the catalogs of a few reliable rose-growers.

February.-Order your new "Made in America" roses.

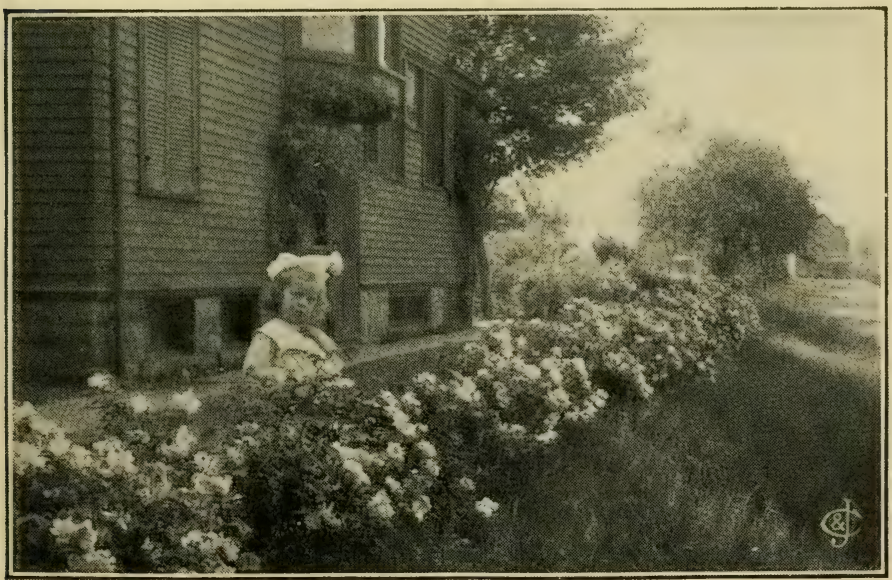

This shows how "York and Lancaster" may be used (page 62) 


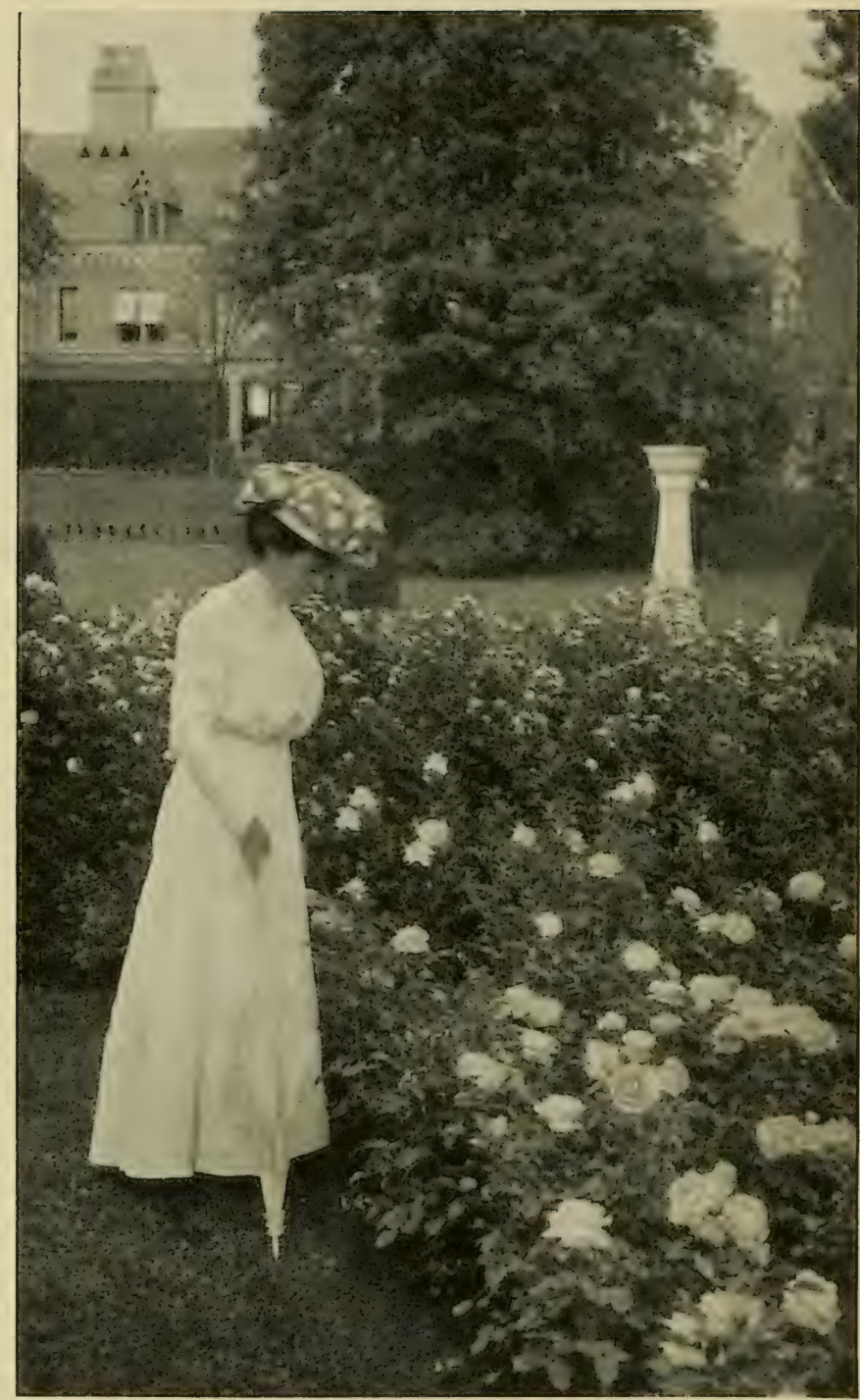

"Just a little garden of these modern well-bred roses; just a little daily, loving care; just a little cost; and the result to you and your neighbors is the glory of the Queen of Flowers," 


\section{Where to Plant Roses}

Several available spaces for the rose-bed are usually to be found on the average home-grounds. The author has had the good fortune to visit a number of rose-gardens that are famous - and others that deserve to be-and this may be said of nearly all: that they lay on the genial, sunny side of a generous group of trees or copse, but were open to the gentler breezes, and were not shut in or shaded.

When buying a new property, the selection of the most suitable spot upon it for the house is scarcely more important than the selection of a site for your rose-garden. You will choose a sunny room, if possible, for the indoor nursery, where "the little fairies" in your home may romp and play on a wintry day; and so, too, will you wish to provide for the happiness and well-being of your rose-children, because only a few of them are prairie-born. Only a small section of this large family has been reared to bear the rigors of gusty, sweeping or whipping winds at any time of year, and from such, for the best results, they must be protected. It is not only the severe, cold winds of winter, or the raw, cutting swish of spring, but the hot, withering winds of summer, too, that may ruin the opening buds and spoil the almost ripe fruits of your Iabor.

Choose a place, therefore, or establish one, protected either by trees, a hedge, a wall, a building, or by some other windbreak. Even a hedge of roses, or climbers, upon a substantial trellis will avail, although a more dense screen is more effective. Choose, too, a place where the sun will shine for not less than one-half of the day, preferably the morning. By this you will see that a space opening away to the south or southeast is to be preferred. We have noted equally successful rose-gardens entirely surrounded by hedges.

Avoid the too close shade of trees, or the proximity of tree-roots; they are ravenous robbers. If the roots can possibly reach over to your rose-beds, they will do it and steal away the nourishment you have provided. Therefore, either keep entirely away from them or, if you must dig your bed 
near them, put in a partition on the tree side to keep back the roots. Boards will do for a time; a concrete wall, about 4 inches thick, will last longer.

Another point to remember is that "roses do not like wet feet." They seem to resent the ignominy of being subjected to standing in undrained ground. Avoid very low. ground for this reason, and also because it is more subject to early or late frost, and has greater tendency to mildew.

Try to combine in your choice as many of these conditions as possible, because, while no point is absolute, all are important. Don't stop or give up for the lack of some one of them. Be earnest about it, and you will soon provide the essentials. Mr. Chapman, the ornithologist, asked exPresident Roosevelt how he continually accomplished so much. Mr. Roosevelt answered that this had been his motto:

\section{"Do what you can, with what you have, where you are."}

That motto will prove most useful for the rose-grower. It lacks, however, one essential, which has been expressed by no other so fittingly, in our estimation, as by Dean Hole: "He who would have beautiful roses in his garden must have beautiful roses in his heart. He must love them weII and always. He must have not only the glowing admiration,

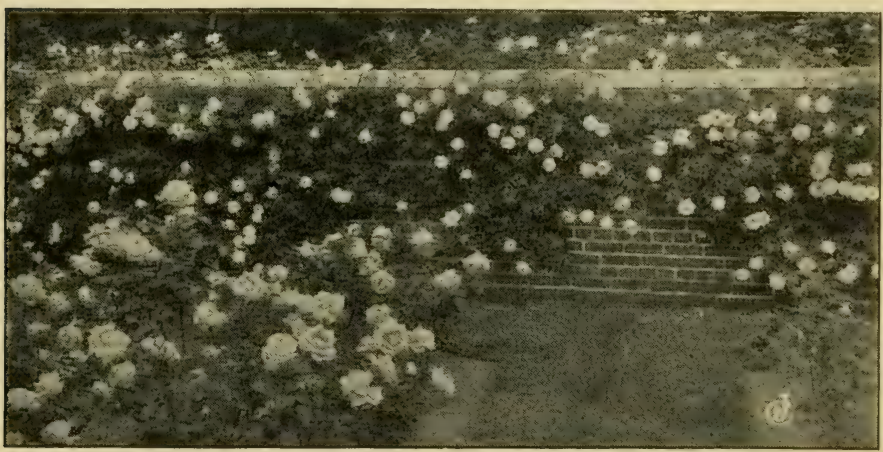

This is Gardenia, running in revelry over the garden-wall 


\section{MAKE A PICTURE OF YOUR LAWN II}

the enthusiasm and the passion, but the tenderness, the thoughtfulness, the reverence, the watchfulness of Iove." The rosarian of beloved memory understood the secret. And would that we

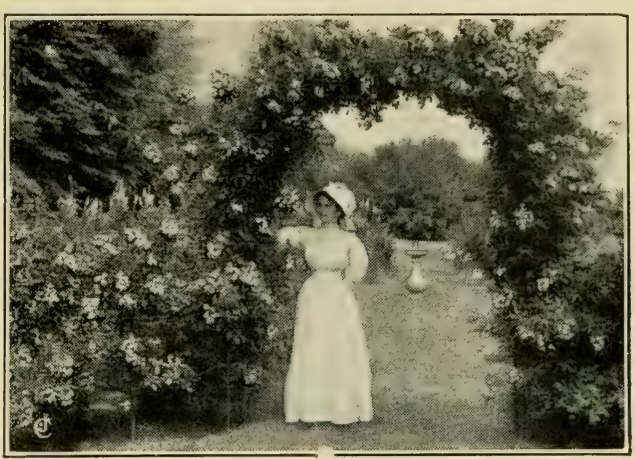

Let climbing roses frame your garden pictures Americans had more, like him, to spread the love for beautiful roses, as well as for the wholesome pastime of planting and caring for the Queen of Flowers.

"Make a picture of your lawn." This is the first principle of landscape-gardening. Leave open the center spaces and plant about and along the edges. Allow this rule to guide you, then select places for your roses where they will do best and give you the most pleasure.

Some varieties, as for example the Rugosas and the"rose species," serve a very useful purpose when planted among the shrubbery. Many other uses, too, are described on pages 64 to 76 . The bush roses, however, including the Teas, Hybrid Teas, and Hybrid Perpetuals, will prove most satisfying if segregated and not mixed too much with other plants.

The location will help to decide the shape of your bed, and it is mainly a matter of taste as to whether it shall be straight, curved, oblong, round, or square. The essential point to remember is this: You will want to get within arm's reach of every rose in your bed, many times in a year, without stepping on the bed. Not over 5 feet in width and preferably $4 \frac{1}{2}$ feet, therefore, is a good rule to follow.

Arrange the roses 18 inches apart each way, unless they are very vigorous growers, in which case allow 2 feet for spread. In warm countries, where the growth is most 
Iuxuriant, and for the big bushy sorts, even more room will be required. Again, there is the other extreme as, for example, in making a border or edging of Polyantha roses, a fine continuous effect may be had by spacing them in the row at only $\mathrm{I} 2$ inches apart.

This diagram shows a bed 3 feet wide for two rows. A bed this width, "staggered,"

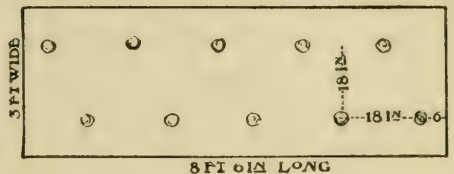
will require twelve roses to every 9 feet, twenty-four roses if 18 feet long, and larger beds in the same proportion.

The young garden in the picture below is well done. Note the avenue effect produced by the double row of Standard or Tree roses on either side of the walk, set from 4 to ro feet apart. They remind one of the beautiful rosegardens in England. Up the wall on either side climbing roses have been started. The front bed on the left in the picture is $4 \frac{1}{2}$ feet square, and contains nine roses. The front bed on the right, if $4 \frac{T}{2}$ feet wide by 6 feet long, would contain twelve roses. The rear bed on the right of the walk is $4 \frac{\mathrm{T}}{2}$ feet wide by $\mathrm{I} 3$ feet long, and contains twenty-four roses; and the long bed in the rear on the left, if $41 / 2$ feet wide by 20 feet long, would contain thirty-six roses.

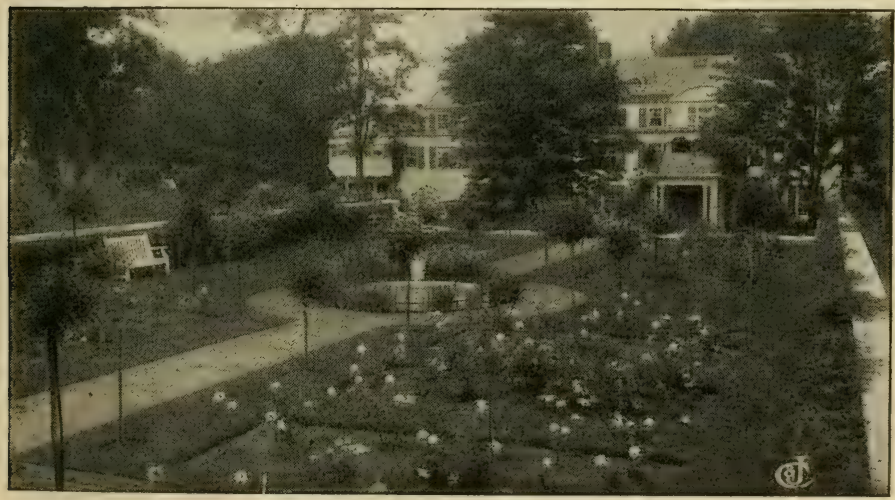

The for nal garden is incomplete without roses 


\section{Preparing to Grow Roses}

Having chosen the location and decided upon the size and shape of your beds, you are next ready to prepare the soil. Rev. F. Page Roberts, an ex-president of the National Rose Society of England, has said: "After years of rose-growing in places far apart, I think it is not so much the soil and the climate, as the care and skill of the cultivator that wins success."

A very successful grower of roses in New York State once remarked to a meeting of his rose society: "I would rather plant a 15 -cent rose in a 50-cent hole than plant a 50 -cent rose in a 15 -cent hole." He was wise. The author recalls visiting a successful private rose-garden in New England one day when the roses in one bed were being moved. Those roses had well-developed roots 3 feet long, because the bed in which they were growing had been prepared to that depth, and the top-growth and bloom had been luxuriantly magnificent, testifying to the value of deep and thorough soil-preparation.

\section{Drainage}

One thing, however, must be provided, if you are to court success, that is ample drainage. "Wet feet" for roses are no more conducive to health and happiness than for children. Examine your soil; if there seems a need, provide drainage, and remove the soil from your bed to the very bottom. Place there a layer from 4 to 6 inches deep of stones not larger than your fist, broken bricks, clinkers, or other suitable material that will readily "take"

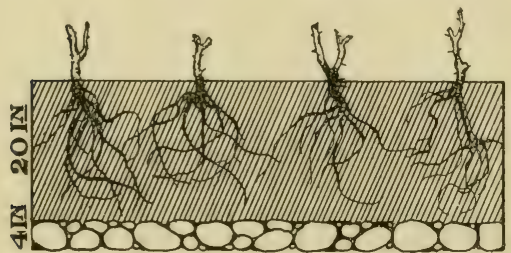

Layers of stones like this are not essential if the ground is naturally well drained the water from above. The soil is seldom so retentive as to require tiling to take the water away and, indeed, nine times out of ten no artifrcial drainage at all will be nee led. 


\section{Soils}

The good loam so often found directly beneath the sod is excellent, but is greatly improved by being broken, even pulverized, to a depth of at least two spades and thoroughly mixed with about one-third its bulk of rotted manure. Fresh manure must never be allowed to touch the rose-roots. Indeed, the more thorough-going way is to make sure of the nether layer of soil by removing the upper one. First of all, peel off the sod (it will produce excellent compost, see section on "Fertilizers"); next take out the top layer of soil to the depth of I foot and pile it nearby. If the soil below that is good, rich loam, or a fair mixture of clay and loam, it may remain. Loosen this with a garden fork to a depth of another foot, preferably not upturning it, and mix with it weIl-decomposed manure, and then put back the top layer of loam in which to plant your roses.

If, on the other hand, you find the subsoil poor, barren, and unproductive, you may have to remove it altogether. Haul it away, and put your chopped-up sods in the bottom, grassside down, to rot and make future plant-food. If you have ready from the previous year a compost made by mixing onehalf or two-thirds of sod, with the balance of manure from the cow-stables, use it in the bottom of your bed, and make a future storehouse of rich nourishment for your roses.

Another hint: A few broken bones may be mixed with the soil in the bottom of the trench, say a peck for a bed holding a dozen roses. These will decay slowly, and furnish plant-food for three or four years to come.

Not all roses like the same soils. The Hybrid Perpetuals, for example, love a heavy clay or loam. So do the heaviergrowing climbers; whereas the Teas, Hybrid Teas, Bourbons and the like, revel in a lighter soil and a warmer one, with less than 50 per cent clay or loam, and more sand or leaf-mold. Rugosas thrive even in quite sandy soil.

"It is diffrcult to give the roses too rich soil." If your soil is light and sandy, and you cannot well replace it entirely, it may be greatly improved by mixing a little clay or rich loam 
with it when trenching. If your soil seems too heavy, it can be made lighter and more open by adding sand, or even coalashes. To be good for roses, the soil must be such as will not quickly transmit to the roots sudden surface changes of temperature. The roots should be kept cool. If it be possible after the soil in your bed has been prepared, give it time, say two or three months, to settle before planting your roses. If this be out of the question, press with your feet each layer of soil in your bed, as you proceed to fill it in.

\section{Fertilizers}

While manure from the cow-stable is best, you can draw upon the horse-stable, sheep-pens, or pig-sty with expectation of good results, and "night soil," mixed with dry soil, or sand, and well composted is excellent. Well-rotted leaves are fair, but too light except for heavy soils. Commercial fertilizers, such as ground bone or guano, may be used with advantage if handled with discretion. A rule to remember is never to let any "green" or "raw" manure come close to the roots of your roses, but see that it is buried well beneath the root reach, or applied as a top-dressing. After your roses have been planted, the best time to apply manures is just as the ground begins to freeze in the autumn. Let it serve as a protection over winter, and dig it in next spring, being careful, however, not to disturb the roots.

Far better than surface-coating is the ample supply of fertilizer placed well under the roots in the bottom of your beds, before you plant your roses, because roots travel toward their food-supply. By thus enticing them downward, you develop a strong, deep root-growth down into the reservoir of stored-up food and moisture, so that, when dry weather comes, they will not hunger and thirst, as they would with only surface roots. Surface application of manure-water is quite a different matter, as that will percolate down to the deepest roots.

It is said that roses draw most upon the soil when blooming, and we find you can almost see the results from application (when the flower-buds begin swelling) of liquid manure, 


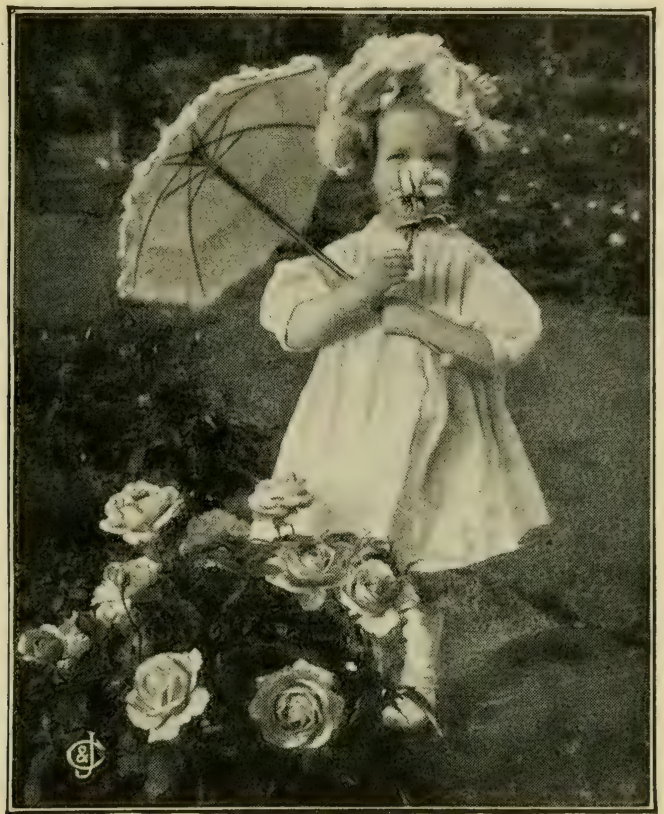

Nearly every child is fond of flowers

concocted by catching the drain from the manure-pile, or one-third of a bushel of manure in a bag and soaked in a barrel of water. Apply this as a weak tea, not too strong, but frequently, say twice a week. When it is more convenient, a sprinkling of bone-dust on the surface before a rain will answer the same purpose. Even with the best care, it may prove necessary in some locations, say after six or eight years, to renew the roses or move the bed, adopting the farmer's principle of rotation of crops.

\section{When to Plant}

TeIl us where you would grow roses, and we will tell you when to plant them. The most carefully laid down dates for New York State are "null and void" in New Orleans. Proper planting-time in the same state may vary according to differ- 
ences in altitude and latitude. Where the winters are not too severe, as in our Gulf and Pacific Coast States, and the

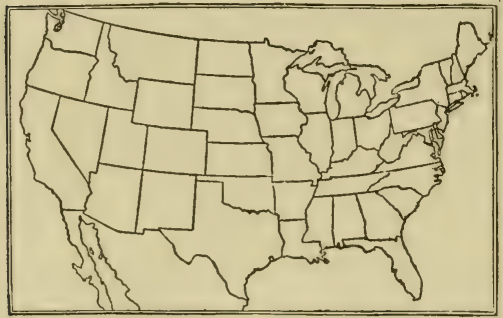
next tier of states north, autumn-planting is to be preferred.

North of the line of the Ohio River, only our hardier varieties, such, for example, as the Hardy Climbers and Hybrid Perpetuals, Rugosas, Moss and Pernetianas, will withstand the first winter out, if autumn-planted. As a matter of general practice, there are, doubtless, ten times as many roses planted in spring as in autumn. For the latitude of Philadelphia, dormant roses should be planted as soon in spring as the soil is dry enough to crumble in the hand, and plantings may continue till midApril. Growing roses from pots should not be set out until danger from frost is past, usually the last week in April. If you live north of 40 degrees latitude, defer planting from this date by one week for every hundred miles. Do not attempt any planting operations with the ground frozen, or the thermometer below 45 degrees Fahr. Roses from pots, when shipped with soil on the roots, may be planted at any time through the growing season, even through the summer.

\section{Treatment on ArrivaI}

Think of your roses as living creatures, even though they be asleep (dormant) when you first get them. Unwrap them with the greatest care; never expose the roots to the drying action of the spring winds for a moment. A plant with bare roots exposed to the dry air is like a fish out of water. Untie the bundles so as not to break, bark or bruise either root or branch. Should the plants, through delay in transit, come dried out, as occasionally happens, soak the balls of earth and roots in water; if the stems also have dried out, bury the whole plant in damp earth for three or four days till the 


\section{TREATMENT ON ARRIVAL}

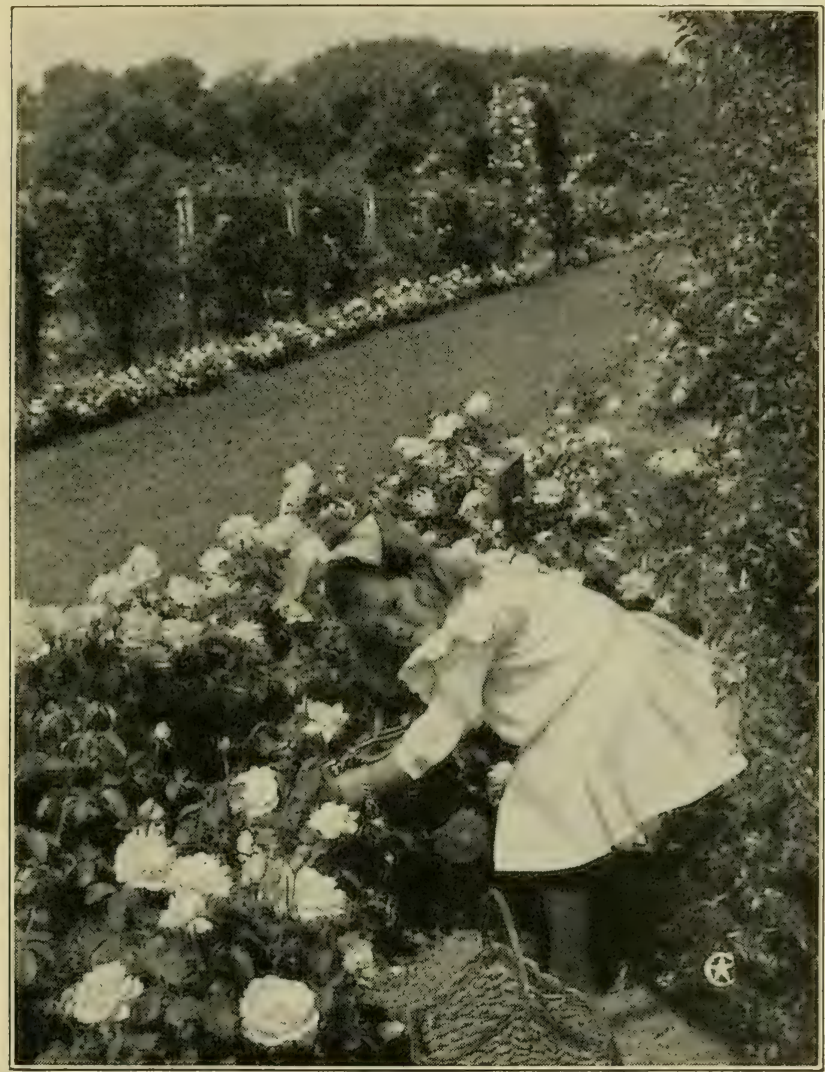

When this little girl grows up and has a garden of her own, she too will know how to grow fine roses.

shriveled branches regain their natural plumpness. If you cannot plant the roses when they arrive, "heel them in" in the garden until you are ready to plant them. This is done by digging a trench deep enough thoroughly to cover all roots and even lower branches of each bundle of roses. It will be better to untie the bundles so that the roots can be more thoroughly covered. Press down this soil-cover firmly. 


\section{Planting}

When ready to plant, remember again that roots must be kept from the wind. Spring winds are so drying that fatal damage may occur from a few minutes of exposure. The best plan, when planting, is to keep the roots covered with a damp piece of burlap, or of other packing-material.

Next make the holes in the bed, which should have been prepared as shown on page I5, and make them large enough to accommodate the roots in a natural and uncramped position, neither too deep nor too shallow (see illustration). Do not spread the roots out flat, but point them down, slanting outward. Use care to keep the roots from direct contact with the manure, lest the roses get indigestion. It is a good plan to dip the roots, before planting, in a thin mud made by mixing loam or clay with water. Settle well-pulverized soil in around the roots, so as to fill up every air-space, and so that every single root shall be entirely encased in soil. When the hole is half-filled, and roots covered, press the soil down firmly with the hands; then fill the hole with water, and let it drain away; fill in level with soil, and tamp it carefully but securely; then give a final covering of soil, which should be about level with the surrounding turf, but not high enough to let the water run away when it rains. Also protect from the bright sunshine for a few days.

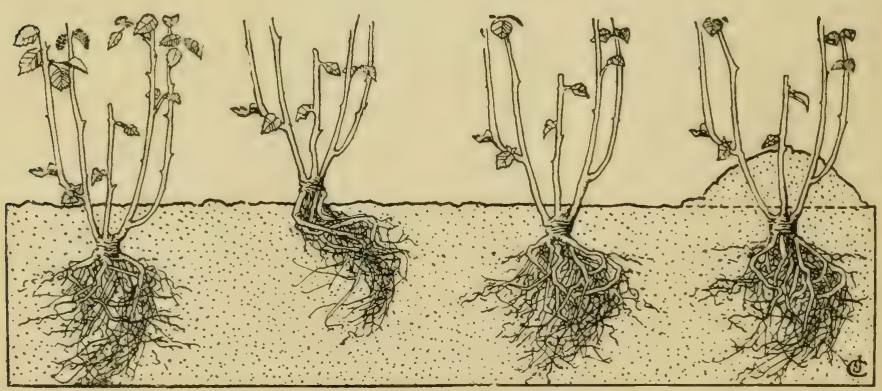

Too deep

Too shallow, and Just right set wrong

Right, and banked for winter 


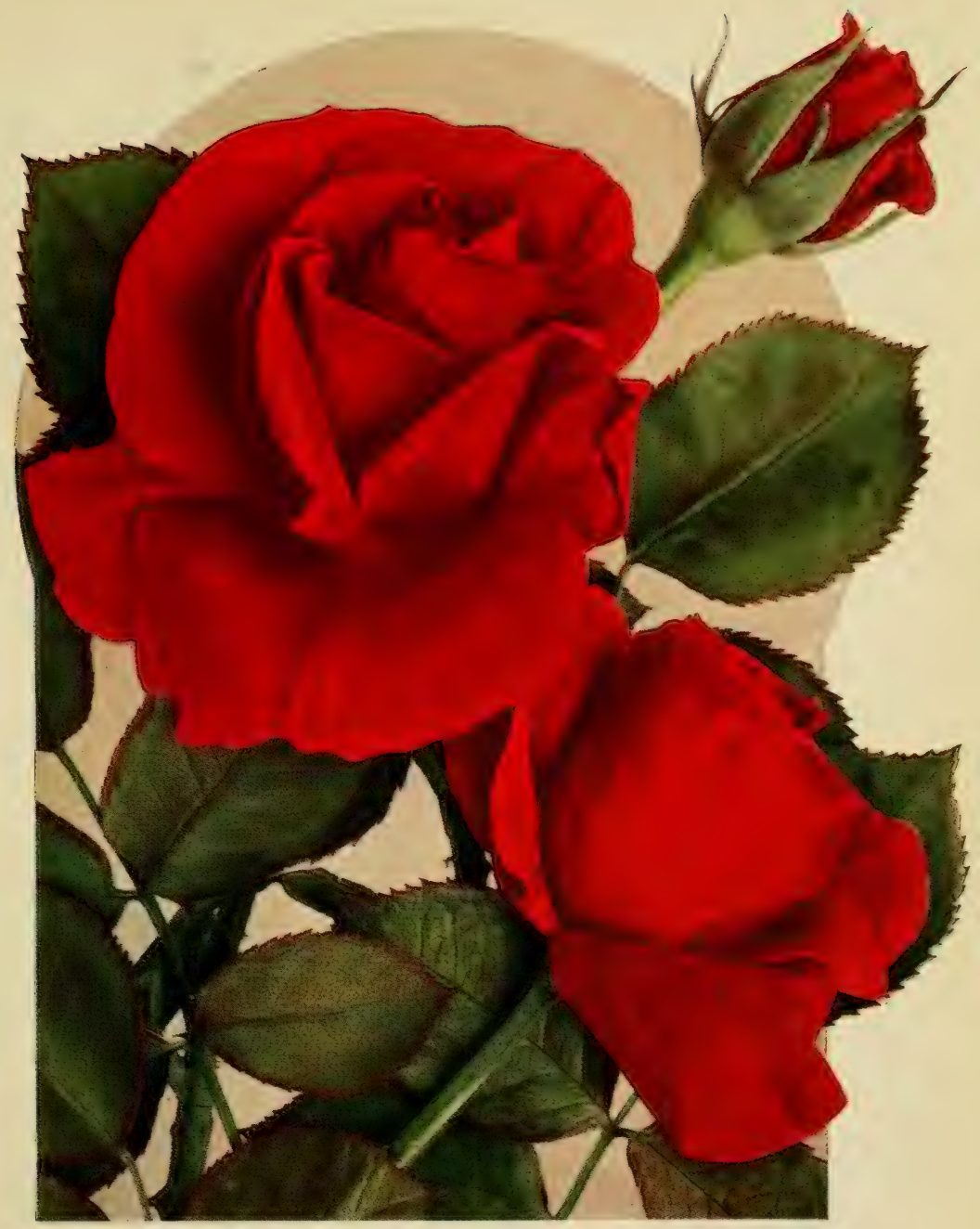

For splendor, beauty and impressiveness the red Rose stands prëeminent, and among the Hybrid Perpetuals the J. B. CLARK, shown above, is a variety with real merit.

Among the more recent introductions in this class should also be mentioned Hugh Dickson, Barbarossa, George Dickson and Gloire de Chedane Guinoisseau.

Can you imagine any flower more exquisitely appropriate, either worn singly or in display for the most important occasions, than a freshly opened bloom like the above?

Important celebrations and state occasions are coming more and more to depend upon the Rose for its decorative value, satisfying the mind and heart, as well as the eyes, of all observers. 


\section{Staking the Roses}

Standard or Tree roses, unless extraordinarily sturdy and planted where they are protected from the winds, will be the better for staking. The stake should come weIl up to the head of the roses. Place it while planting, for if it is driven later it may injure an important root. Bush roses seldom need staking when planted, although this is a matter for attention according to the needs of individual varieties. Plants should never be permitted to sway about or become loose at the collar. If the sun be warm within the next day or two after you plant, the bush will be the better for being shaded, as well as for mulch about the roots.

\section{Labeling}

Rose-growing with Iabels is by far the most delightfuI kind. You lose half the pleasure if you lose the names, to say nothing about the satisfaction of accumulating information. The importance of labeling is really great. Do it when you plant as a part of the operation; otherwise, it is likely to be overlooked. The growers' labels are not likely to last more than one season, and then it becomes dreadfully embarrassing not to know what to call your plant-children, whether you want to scold or caress them. Choose the Iabel with fewest faults.

\section{Copper Labels}

These are made of light sheet copper, eyeleted and wired ready to use as soon as the name of the plant is inscribed. The copper labels are very light, and are therefore most suitable for hanging on the branches of your roses in a conspicuous place, not to be disturbed until you begin your pruning. Then, if necessary, remove them to some other part of the plant not in danger from your shears. But any type of label that must be wired on the bush may constrict and check the life of the stem or branch on which it hangs. Therefore, a better way 
for ink, page 23) so that names and dates are not lost by rust or peeling, as on iron labels; and, if by chance the name has to be erased, this can be done with emery cloth. Only one size is made, viz., $9^{1} / 2$ inches in length, by $3^{\mathrm{I}} / 4$ inches in width at the top.

\section{The Simplex Label}

The Simplex labels have recently been greatly improved. You should know them. Placed securely on the top of a suitable metal stake, 16 inches long, is a $1 / 2$-by $23 / 4$-inch metal frame, with solid back, tilted at an angle of about 45 degrees, whose legend is easily read and weatherproof. In this frame is a slightly roughened celluloid card on which to write the name, date, etc., with a pencil, and over this, for protection, is slipped in a clear smooth piece of mica. They are too new to have been tried thoroughly, but we predict wide use for them. They are painted neutral green, and in every respect seem, to the writer, calculated to meet the tastes and requirements of the most exacting. The objection which some people have for labels is that they are so unsightly and spoil the appearance of the rose-beds, but the wire-staked green ones are most unobtrusive. The most elite roselabels we have ever found were those used by M. Gravereaux, where, on top of metal stakes were screwed flat, oval name-plates of porcelain, with the names burned in.

\section{Platting}

But the "best laid" labels sometimes go wrong, and in some unexplainable fashion do get lost; therefore, to be entirely protected, you can take out label insurance. Some people think this is more important than labeling. Draw a diagram of your bed, and then with letters or numbers indicate on it the location of each rose. With this make out and keep a key-list of roses lettered or numbered to correspond with those on the diagram. We venture to predict that such a list will prove its value before the end of the second year. 


\section{Mulching}

There is a double object in this: First, to retain the moisture; and, second, better to preserve a suitable temperature in the soil. What is called a "dust-mulch," maintained by frequent hoeing, is, perhaps, the best method, although, where the summers are warm, a covering in early July of Iong "strawy" cow- or horse-stable manure that will not heat, will accomplish the same object. The illustrious amateur rose-grower, George C. Thomas, Jr., of Chestnut Hill, Philadelphia, Pa., keeps the surface of the soil in his beds about 2 or 4 inches below the boundary turf, and then he fills the beds level full with peat-moss, which acts not only as a mulch, but effectually stops weed-growth. This we look upon as even better than a manure-mulch, because the latter may encourage root-growth nearer the surface than is desirable. We have also tried sawdust for covering the beds in summer. It certainly prevented need for weeding and otherwise seemed beneficial.

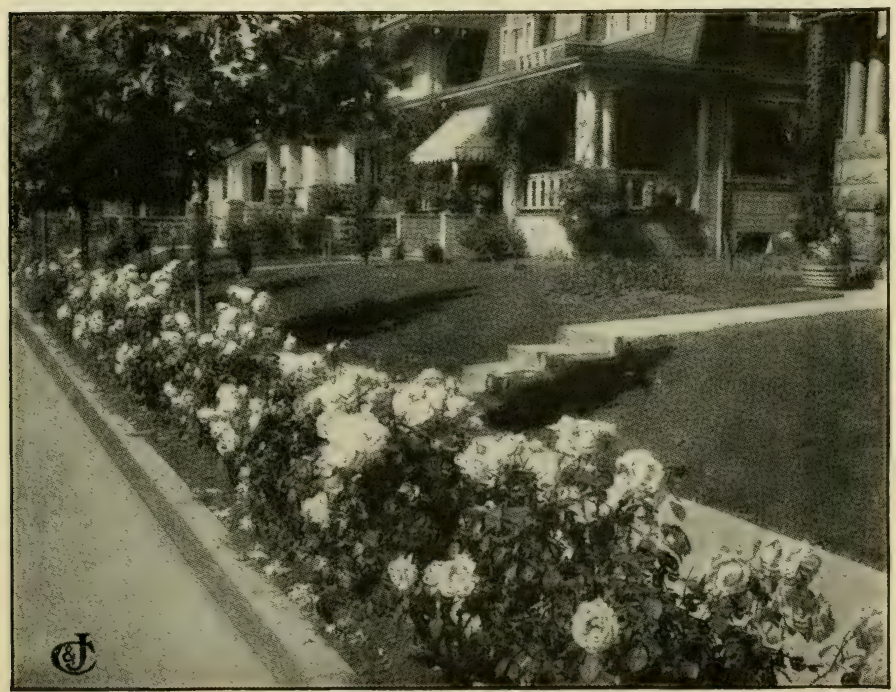

Roses where everyone may enjoy them 


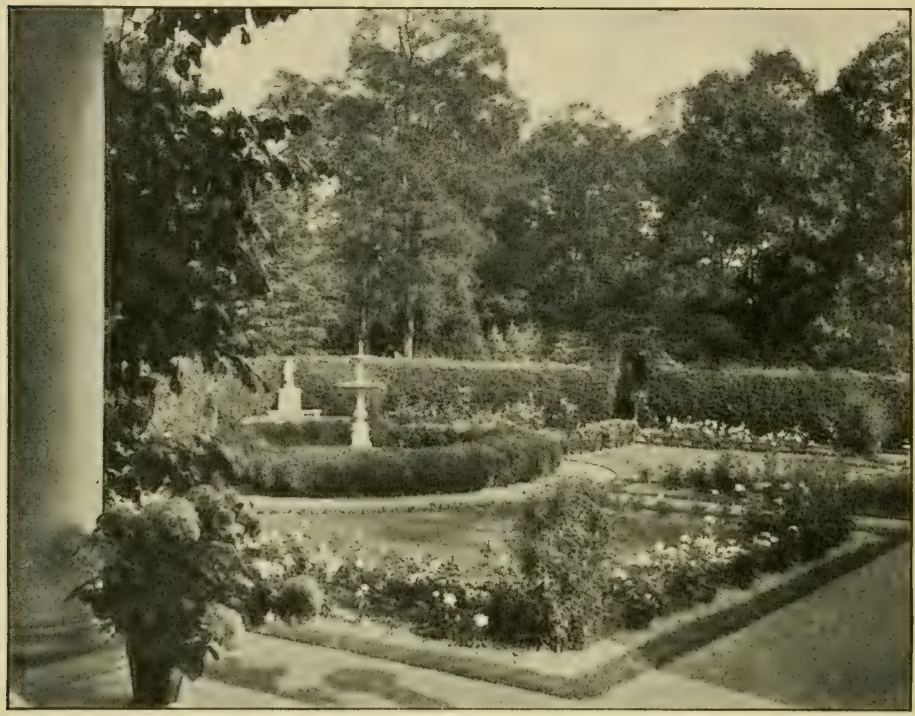

Roses in the outdoor living-room

\section{Protecting the Roses \\ From Frost}

W. C. Egan, the eminent horticulturist of northern Illinois, succeeds admirably in keeping his roses over winter, as also does Mr. Orpet, Superintendent for Mr. McCormick; and yet, north of Chicago, where they live, the severe winters and the cold winds blowing over Lake Michigan, often kill the Wichuraianas and Rambler roses to within a foot of the ground, when not protected. An eminent judge, living north of Detroit, by the work of his own hands, protects his Hybrid Teas so that they triumphantly weather zero winters. On the famous shore-front at Newport, Rhode Island, we found the tender Gloire de Dijon rose, which we had supposed could not be grown north of Washington, D. C., green and thrifty to the second story, after a most severe winter season. But the protection had been very thorough. 
Obviously, there is no danger where there is no frost. Where the thermometer falls below freezing, the less hardy varieties should be partly covered, and all roses will be the better for some protection, at least about the roots. If you are visited with zero weather, let "preparedness" be your rule. To begin with, bank up the soil cone-shaped, with the apex 6 to Io inches high around the stem of each bush. Ashes are sometimes used, but nothing we know of is better than soil. In very cold countries, the roses may be lifted entirely and buried in trenches for the winter, and they will come out in fine shape for replanting in spring. After you have drawn the soil nicely around them (see calendar), leave them alone till the ground is frozen with a crust hard enough to bear the weight of a stone-laden wheel-barrow. By this time the moles or mice, or other creatures, will have secured their winter abode elsewhere, and not be tempted to make nests in the protecting material you will next apply. Now do not smother your roses, or they may die. Cover them thoroughly, as high up as you attempt to protect them, but always allow for the circulation of air. A 3-or 4-inch blanket of good, heavy stable-manure will keep out much cold. Over this fill up from the bottom of the bed to a depth of 10 or 12 inches with nice, dry leaves, and with some light material on top to keep them in place. A 12 -inch fence of poultry-wire staked round the bed will help keep the leaves in place. The boughs of fir or pine trees, hay, straw, or cornfodder, or other material that will break the force of cold, biting winds, will serve in place of leaves, and where most careful protection is required, boards may be arranged roof-fashioned to turn off the rains. This will also protect your roses from exposure to direct sunshine when nights are freezing-cold, and avoid alternate thawing and freezing, which is dangerous, and in early spring prevent the premature excitation of plant-growth and tender buds. For this reason, too, remove protection in spring gradually, and not all at one time (see calendar).

A method that has proved successful in one of the coldest sections of the United States is thus vividly described: 


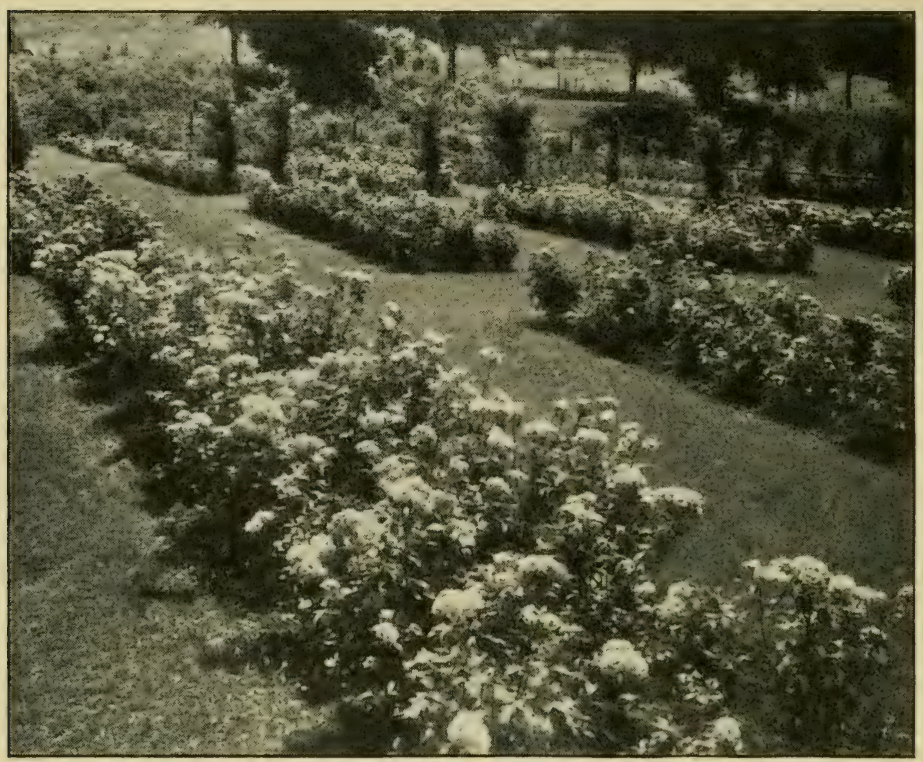

Minneapolis Municipal Rose-garden

“. . Our principal problem would be to provide proper winter-protection. We took special pains to ripen the wood. We stopped watering and cultivation in September, and discouraged late growth. The last week in October we gave the beds a very thorough soaking, and a few days after we tied the shoots close together, and piled the soil around the plants as high as we could with material taken from between the plants, so covering from four to six of the lower eyes. The garden was then left in this condition until there were 3 or 4 inches of frost in the ground. We then filled in with dry leaves, gathered from the nearby woods. The leaves were thrown in loose and not packed down, and covered the beds to the height of the soil heaped around the plant. We then boarded in the long sides of the beds 2 feet high, and boarded over the top of the bed, but left the two ends open. Over this board cover we spread a layer of bedding, straw and hay. 
"It will be seen by the method of winter-protection herein described that our aim was to prevent, if possible, thawing after frost had set in; to protect the plants from the drying effects of the strong winds, without preventing the free circulation of air. We have employed the same method of protection ever since, and generally we have been successful in bringing the plants through winter in very good condition." (Article, "The Minneapolis Municipal Rose-garden in Lyndale Park," by Theodore Wirth, in "The American Rose Annual," i9r6, pages 79, 80.)

Protecting Tree roses over winter is most important. Set up a box about 2 feet square, and high enough from the ground to encase the head, and fill this with soil to cover all but the topmost branches. No part needs protection more than the point where stock and branches join. Another method is to loosen the earth on two sides of the plants so they may easily be bent over without breaking anything and then, when staked to the ground, cover with 6,8 or more inches of earth till danger of frost is past in spring, when they may again be reinstated and restaked. In some locations it may prove quite as convenient, and equally effective, to take up the plants entire, and bury them in a trench in the vegetable garden.

\section{Protecting Roses from Enemies}

Eternal vigilance is the price of perfect flowers, because "prevention is better than cure." Vigorous, healthy plants are seldom troubled much.

The two golden rules to remember, says Mr. Edward Mawley, Secretary of the National Rose Society of England, are these: "Keep sharp watch out for the first appearance of insect or fungoid pests and adopt measures for destruction at once. Then persevere with the remedy adopted until a cure has been effected."

Our Lady Rosa likes cleanliness above all things, and wiII respond generously to these attentions. Keep your roses clean and healthy and they are almost certain to be happy. 


\section{Insects}

Probably our worst enemy to roses is the Rose Chafer ("Rose Bug"), which is particularly severe on sandy soils. For this, handpicking into a vessel of kerosene is effective, or a half pound of arsenate of lead in twelve gallons of water, or bordeaux mixture (one ounce to one and a half gallons of water). Spray on every two weeks through June and July as a preventive. This is also a good remedy for the Rose-Slug, which skeletonizes the leaves. It works from the under side of the foliage so when going after it, turn the foliage down side up and spray it thoroughly.

Aphides, or Green Flies, attack the plants during May and June, and, if not dispatched, they multiply rapidly, and suck the life-blood from the leaves. A vigorous spraying of Thompson's rose nicotine or whale-oil soap will settle them. SCale seldom bothers any except old, neglected shrub roses. Use scalecide or lime-sulphur wash.

\section{Diseases}

Of the fungous diseases, Powdery Mildew is by far the worst and most difficult to overcome. It will be recognized as a white mold appearing on the foliage, which, if not checked, will spread.

This is most likely to occur in warm, damp weather, and certain varieties, such as Crimson Ramblers, are more subject to its attacks. Bordeaux mixture, applied at fortnightly intervals, is a good preventive (see formula above). As a cure, flowers of sulphur dusted on the foliage is recommended, also "grape dust." For Black-Spot, Rust, and other fungous diseases, follow the same course. Also promptly remove and burn foliage thus affected.

Bud-Rot. Outer petals turn brown and buds fail to open. No satisfactory remedy is known.

The beginner need not be dismayed at the above array of troubles that may happen; if they do, these hints are offered as a "first aid to the injured." As a matter of fact, not all the above pests are likely to appear in the same garden. It is not so complicated or difficult as might appear. 


\section{Pruning}

If you have bought two- or three-year-old plants, cut them back rather severely at the time of planting - to three or four buds on the Hybrid Perpetuals and about six on the Teas and Hybrid Teas. Always cut the stem just above a bud that points out, never above one that points toward the center of the plants. The term bud or eye is used to define the places on the stem where leaves will be produced. They are easily distinguished, as they look like small, pointed warts on the stems. If the plants are in leaf when planted, the above does not apply. The crop of flowers on the rose plants is largely governed by the kind of pruning the plants receive. In fact, other conditions being ideal, the pruning determines the quantity and the size of the flowers.

The Hybrid Perpetuals and most other hardy roses should be pruned in March; if weather permits, by the

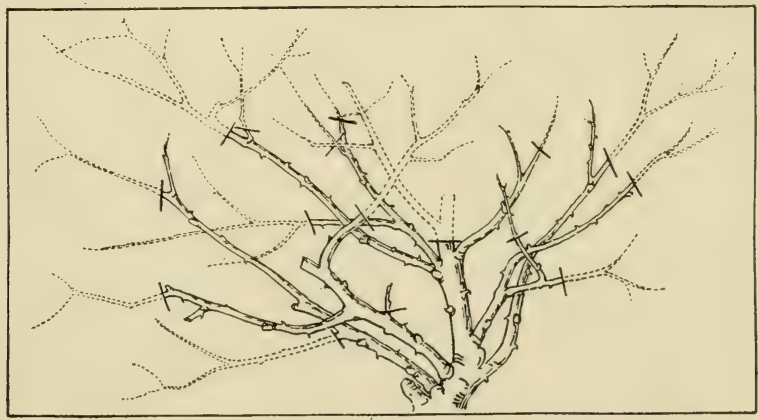

Method of pruning Hybrid Teas for garden display (As recommended by the N. R. S. of England)

middle of the month. The tender roses, the Teas and Hybrids Teas, need not be pruned until along in April, when the sap begins to flow and the buds begin to swell; for, at this time, dead and weak wood may be much more easily distinguished and cut out than earlier in the season. Besides, it is an advantage to leave the mulch undisturbed until settled weather has arrived. At the time of pruning, one must 


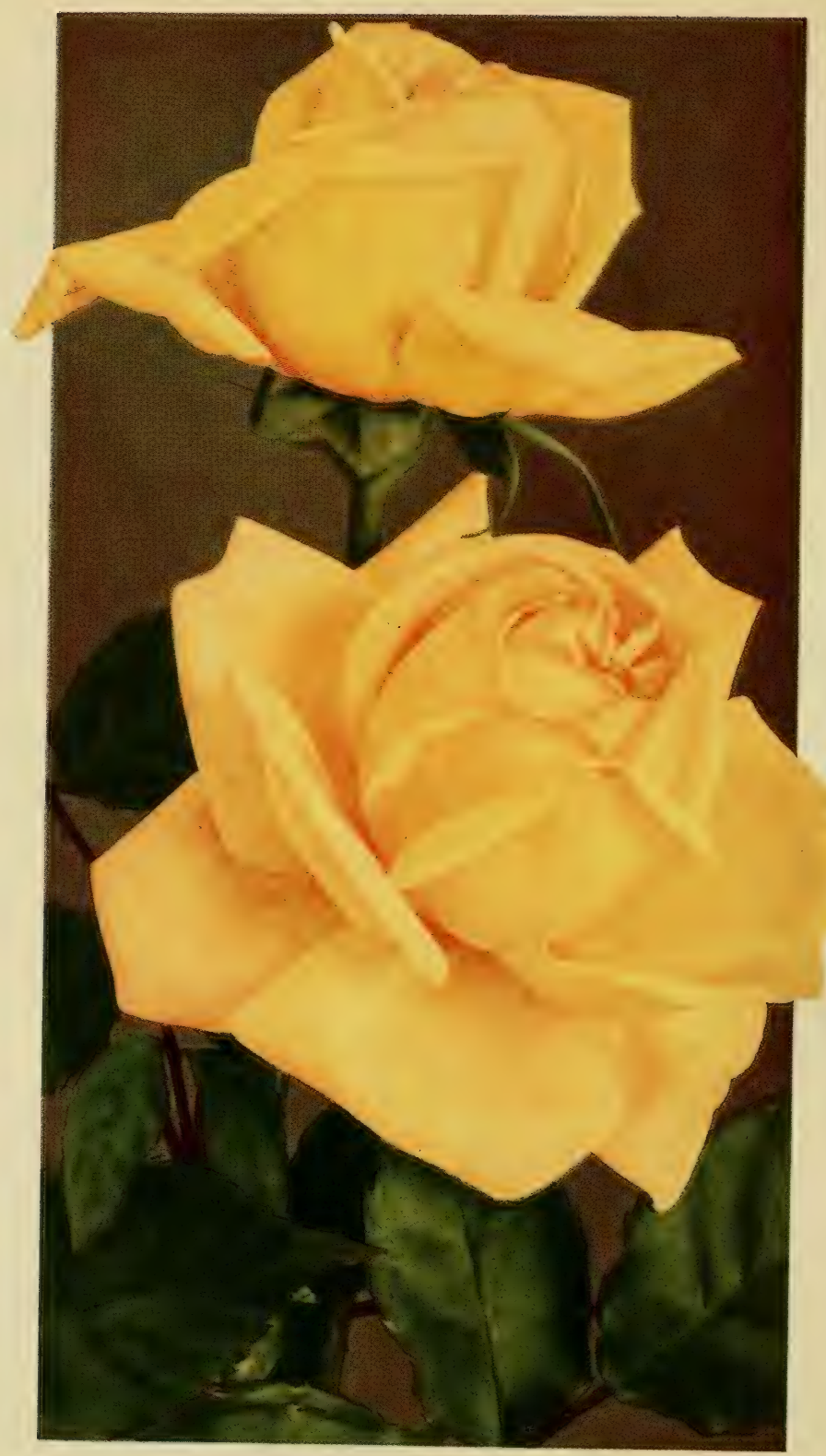

The PERLE DES JARDINS is a standard Tea Rose of rich golden yellow color and fine form; it blooms freely on strong stems. Other newer Roses of related color and great merit are Lady 
decide upon the kind of crop wanted. If the very biggest and best flowers are wanted, then severe pruning is necessary (see I, page 34); if a large crop of average flowers, then only moderate pruning (see 2, page 34 ); but, where a quantity of bloom is preferred, only a little pruning is necessary (see 3, page 34).

When pruning Hybrid Perpetuals, first cut out the weak wood and any branches that cross; then cut back the strong canes to about six eyes, the top one pointing out, and the cut being made one-quarter of an inch above the. bud. If you want only a few big flowers, cut back to only three or four buds. For the big outdoor display, leave four to seven canes twothirds their growth. The Teas and Hybrid Teas will need the same attention, but there should be as much or more wood left. In case the winter may have killed the canes, cut back to live wood, even if down to the surface of the soil.

These rules are modified somewhat by the character of the plant. The weakergrowing varieties can be cut back farther than strong-growing sorts. The stronggrowing kinds, if cut back too heavily, will run to wood, and in the case of someGloire Lyonnaise, for instance-too heavy pruning may kill the plant.

The Bourbon roses need but little pruning. Cut back the stems a few inches. This is also true of the Austrian Briar roses, of the Wichuraianas and the Ramblers, which should not be pruned much in autumn or spring, but just after the flowering season, to produce wood for next season's bloom.

Climbing and Pillar roses need be cut back but onethird to one-fifth, and on old well-established plants, the old, enfeebled wood should also be taken out.

The base of the branches may be prevented from becoming bare. In straight branches, the sap goes to the top, leaving 
little for the buds at the base. Train the branches up crooked by putting sharp bends in the stems within 2 feet of the ground, and foliage will be produced the whole length of the stem. To get a second crop of flowers in autumn, cut 8 to 10 inches of wood with the flowers. Several Hybrid Perpetuals will also bloom in autumn with this treatment. (See below, and

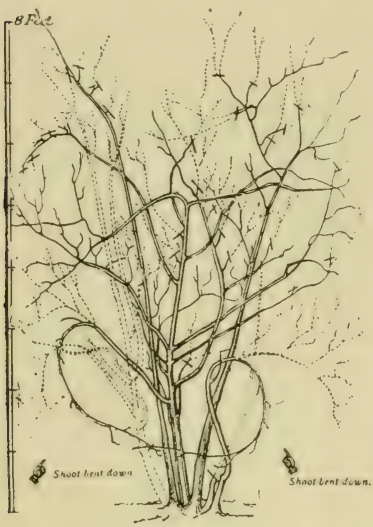

The way to prune and thin out climbing roses also the list of 158 roses on pages 43 to 62 .)

In autumn extra-long canes will need to be cut back a little, and perhaps tied to a stake or support, to prevent swaying and the consequent damage to the roots.

\section{How to Use This Pruning Information}

Refer to pages 43 to 62 for varieties on which information is desired. Opposite each name will be found abbreviated directions for pruning. Illustrations herewith will further explain the instructions. The key to these directions is fully explained on this and the succeeding page.

I. HARD. Thin out to the base all but from three to frve shoots, and cut these back so as to leave two or three eyes on each shoot.

2. Moderately Hard. Thin out as No. I, and cut each shoot back to about frve to ten eyes.

3. Medium. Thin out as No. I ; leave four to seven shoots; shorten these shoots to about half their length.

4. Sparingly. Thin out as No. r; leave four to seven shoots, which should be merely tipped.

5. Thin. No pruning required; thin out annually.

6. NonE. No pruning required; thin out every two or three years, just to keep the plant within bounds.

7. Climbing, Pillar, and all other roses that are marked 7 can be improved by thinning, when one or more of the 
stems show plainly that they are old and past doing good service. This should not be necessary oftener than every three years. Kinds marked + are more likely to need it than kinds marked -. The needs of such roses as Mrs. Peary, Marechal Niel, etc., are not covered by any of the notes, where the climate is warm enough not to kill back the main stems. In this case, the branches should be trimmed so as to leave from two to ten eyes.

Ex. Method to use to produce exhibition specimens or large flowers.

Q. Method to use to produce showy bushes or a quantity of flowers.

"Note I.-Pruning, therefore, is the art of improving the productive power, and the appearance of the plant. It consists of two distinct operations: (I) The removal of dead, weak, overcrowded, or otherwise useless shoots. Unripe wood which in the spring will usually be found to have discolored pith, caused by the winter frosts, should be cut clean away at the base of the shoot. (2) Pruning proper, the shorten-

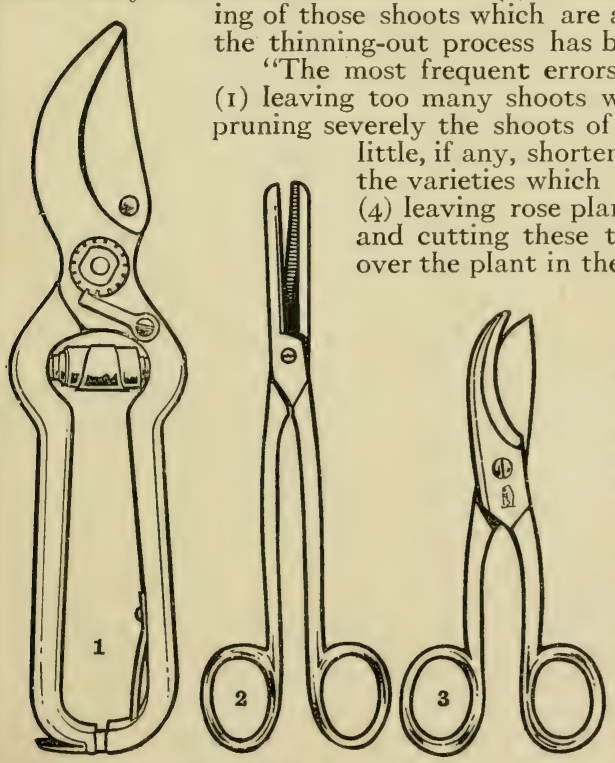

1. Pruning-shears for heavy work

2. Flower-scissors that cut and hold the stem.

3. Flower-scissors strong and convenient for light work. is clipped.

"In thinning out a shoot, it should be either cut clean away to the base of the plant, or to its starting-point on the older shoot from which it springs, as the case may be. When the plant has been pruned, the shoots should be left as nearly is possible equidistant from each other, and reguIarly arranged around it so that it presents a well-balanced appearance on all sides."National Rose Society's Hand-Book on Pruning. 


\section{Own-Root, and Budded or Grafted Roses}

Every rose-grower should learn the difference. In a budded or grafted rose, the top of a good flowering variety has been joined and made to grow onto the root of a "wild" rose. An own-root rose never borrowed roots. It stands on its own feet, so that, if the top be winter-killed, the new growth from the root will bloom true as at first. Not so with the budded or grafted rose. If the top be killed, the "wild" root is worthless; throw it out.

As a general rule, for application over a broad area, the experience of many people in many different localities indicates a preference for own-root roses in as many varieties as will make satisfactory and vigorous growth.

Some varieties, however, when grown on their own roots, are not thrifty and vigorous. Such kinds should be obtained in plants that have been budded or grafted onto roots of a

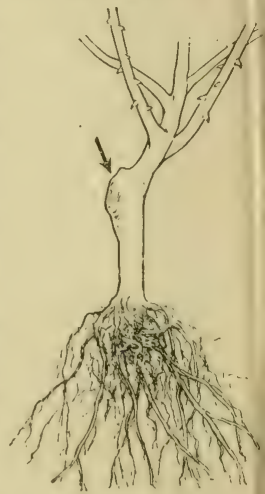

A budded rose may be distinguished from the own-root by knotformation of the former. See arrow. stronger-growing rose in order to obtain the desired growth and abundant bloom. Multiflora, Canina, Manetti, and other stocks are used for this purpose. When planting ownroot roses, set in the soil a trifle deeper than the stain of the soil on the stem indicates it grew before. When planting budded or grafted roses, set with the joint or union of top and root an inch below the surface of the soil, and watch for suckers. If there appears any growth originating below the union, dig away the soil and cut it off close up to the stem;

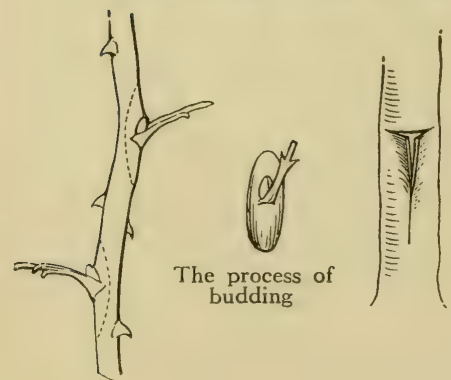
otherwise it may
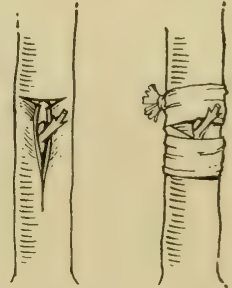
grow up and crowd out the flower-bearing part of the plant. These suckers usually show 7 or 9 leaflets. 


\section{Selecting the Roses}

This is a vital matter. The most complete and authoritative list of roses in our possession shows $\mathrm{I} 0,28 \mathrm{I}$ varieties. The most complete collection in any one plantation that has come under our observation we did not attempt to count. It is said to contain about six thousand varieties, including every known species and every variety now obtainable in the civilized world. (This garden, the Roseraie de L'Hay, will be found more fully described on page 98.)

The average number of roses actually in commerce in the

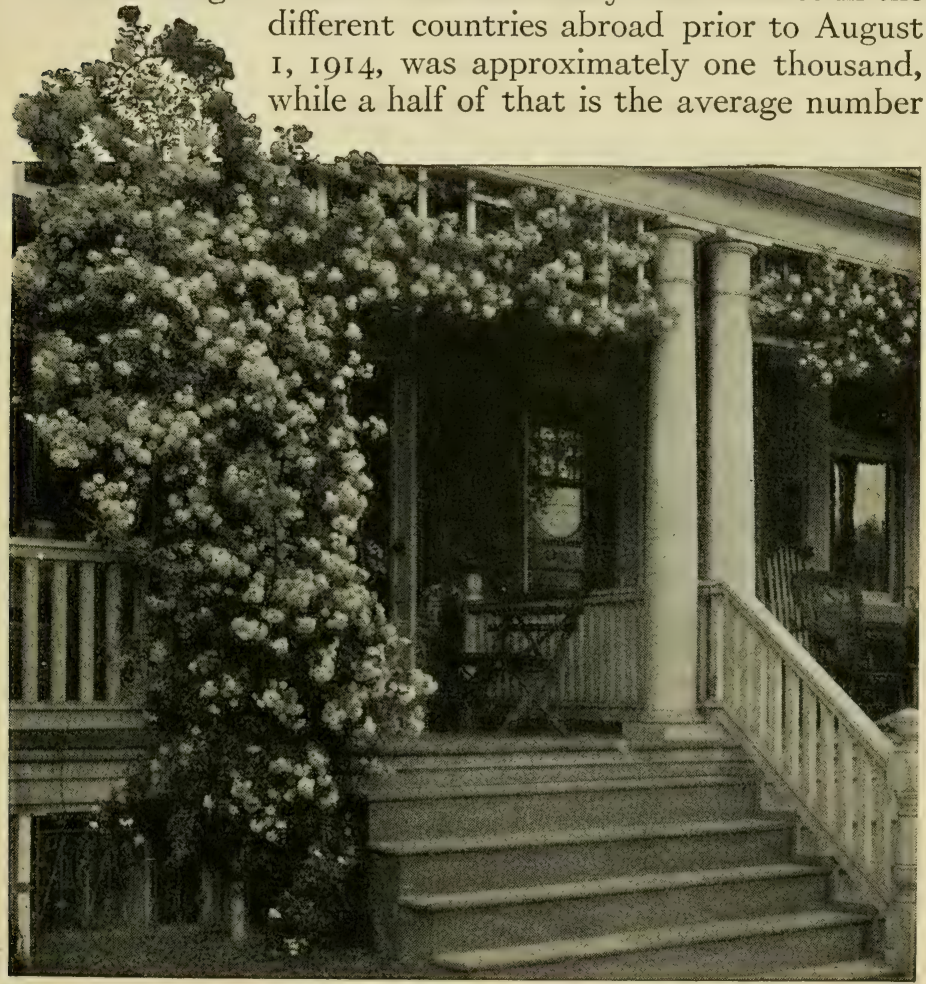

The Iuxuriant clusters of the white-flowered Dorothy Perkins. A good example of the Wichuraiana family 
offered in America by the leading rose frrms whose products can be relied upon as true to name.

When we recall that the average amateur must confine his selection to a much smaller number even than this, often a choice two dozen kinds, the paramount importance of a proper selection is quite apparent.

Dr. Liberty H. Bailey, formerly of Cornell University, and editor of that standard authority, "Cyclopedia of American Horticulture," says: "The success of the rose in this country is very largely a question of the selection of adaptable varieties."

Pemberton, in his excellent work on roses, says to beginners: "State your requirements to a friend who is an expert and leave the selection to him." This book would be a "friend" to every rose-grower,-how "expert" you must judge from its contents.

America is a big country, and allowances must be made for differences in soil, climate, and other conditions. Rules are offered for use and application by the reader to the conditions that obtain in his or her locality. If there arise conditions not herein covered, the author will be glad from his own experience to assist readers in solving their individual problems.

Where do you live? The answer to this question is the first key to the selection of the right roses. Some varieties will withstand severely cold winters from which other varieties would die. Do you want dwarf, bedding, pillar, or vigorous climbing roses? Would you prefer a great show for a month or more in the early summer, or a more or less continuous bloom throughout the autumn also? These various important characteristics will be mentioned in the descriptions of 158 roses on pages 43 to 62 . The following explanations will enable you more fully to understand the terms used. We state after the name of each rose: (I) the class to which it belongs; (2) the color of the flower; (3) the character of the leaves, when it is particularly worthy of mention; (4) the character of growth (vigorous, moderate, etc.); (5) the purposes for which best suited; (6) the way to prune 


\section{SELECTING THE ROSES}

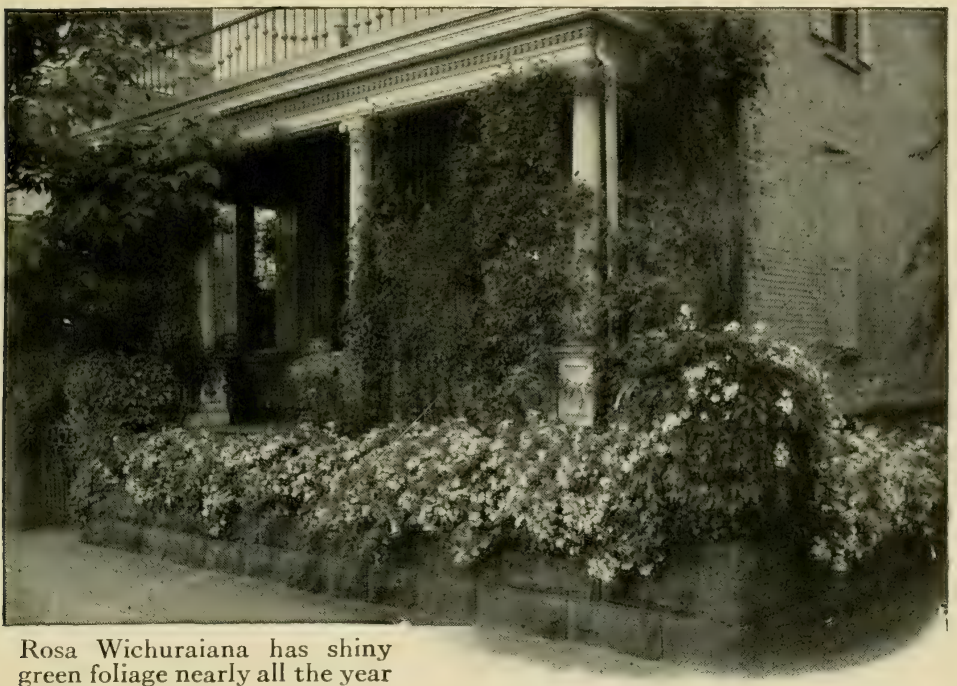

the variety; (7) other noteworthy remarks. We have endeavored to avoid all exaggeration.

After the name of the variety, the class to which it belongs is indicated by the following abbreviations:

\section{Section I}

T.-Tea

B.-Bourbon

C.-China

H.T.-Hybrid Tea

P.-Polyantha

T.P.-Tea Polyantha

Section II

N.-Noisettes

C.T.-Climbing Tea

C.H.T.-Climbing Hybrid Tea

C.P.-Climbing Polyantha

C.T.P.-Climbing Tea Polyantha
Section III

A.B.-Austrian Briar. Per.Pernetiana, or Hybrid Austrian Briar

D.-Damask

H.P.-Hybrid Perpetual

M.-Moss

Pr.-Provence

R.-Rugosa and Hybrid Rugosa

\section{SECTION IV}

Mult.-Multiflora

Bank.-Banksian

CI. M.-Climbing Moss

S.B.-Sweetbriars

W.-Wichuraiana and hybrids

In addition to 158 leading roses listed on pages 43 to 62 inclusive, see also (pages I I o to I I5) a list of the important roses in each class named above. 


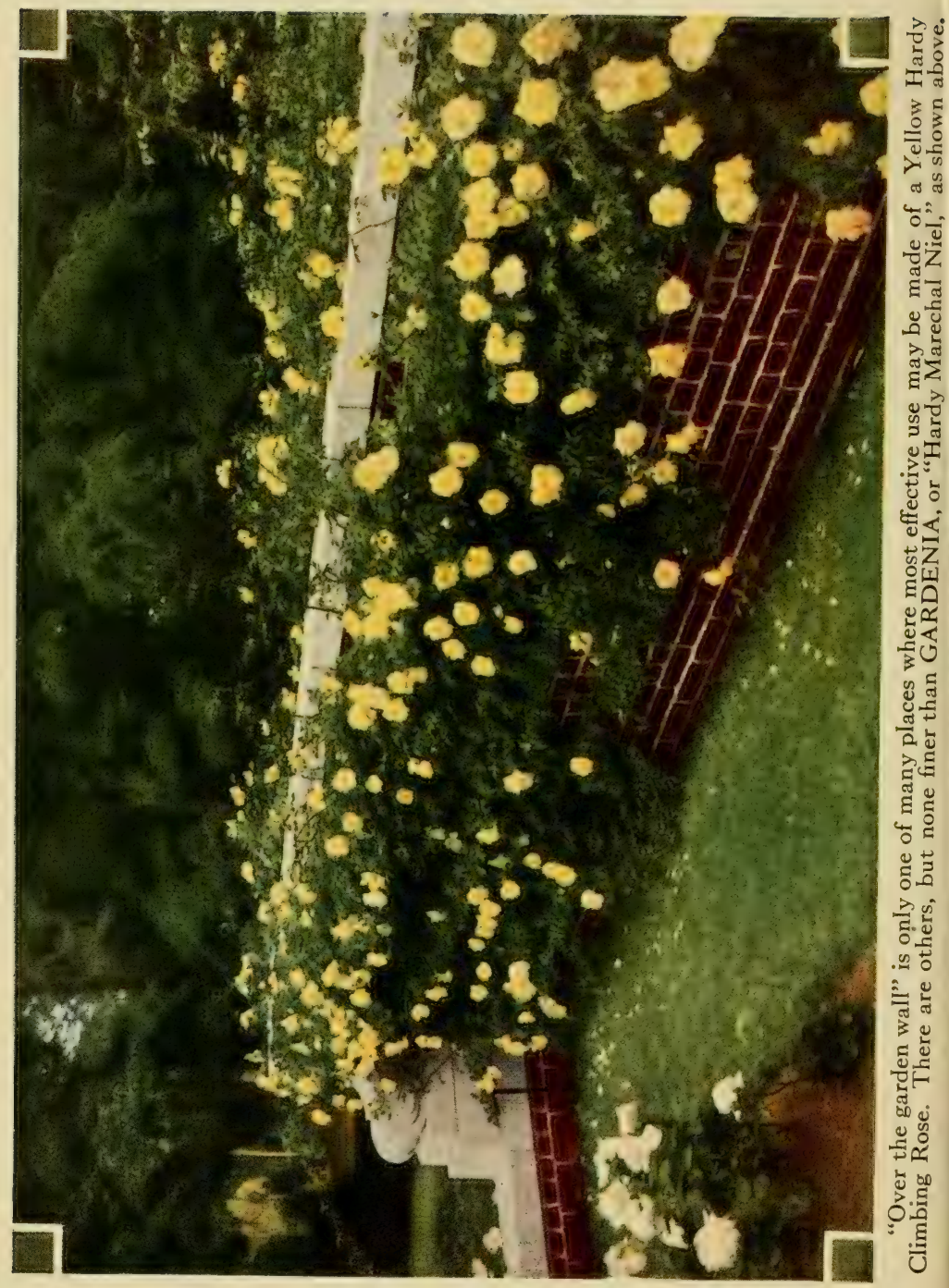


It will be helpful to remember, when referring to the above four sections, that sections III and IV contain the hardiest roses. Roses in these classes will live out over winter in the latitude of Philadelphia without protection, although all roses in this and colder regions will be the better for protection. The classes in sections I and II require carefuI protection in a climate like this, especially the frrst ones named in each section, which are better suited for growing south of Washington, D. C., and in correspondingly mild climates.

As to bloom, sections I and II will bloom more or less throughout the growing season. Sections III and IV are mostly known as summer bloomers, and are in their greatest glory for only a few weeks in early summer. Some of the Hybrid Perpetuals and Hybrid Austrian Briars will also make an autumn showing.

The character of growth is indicated upon a scale arranged as follows: Weak, moderate, moderately vigorous, vigorous, very vigorous; "robust" indicates sturdy and bushy, but short growth. Climbers are described either as vigorous climbers, suitable for low pillar or trellis, or very vigorous, suitable for archways, pergolas, or high trellis.

\section{Terms Used to Describe Appropriate Uses}

(Also key to descriptions on pages 43 to 62)

GARDEN.-Recommended for general lawn or garden cultivation.

BEDDING, i. e., free-flowering and of rather compact growth-good for massing in beds, either several of a kind or with other bedding roses.

Pillar.-Excellent for training up to a low pillar, stake, or post.

ARCH.-For covering an archway.

Pergola.-For growing over a pergola.

WALL.-Suitable for training up the face of a wall or side of a building.

Creeping.-Good for covering a bank, stumps, rocks, etc. 
Trellis.-Grows well on a trellis.

Bush.-Makes a good bush when planted alone and allowed to develop.

Рот, or Cut-Flowers. - Those that have particularly Iong stems and other qualities that make them peculiarly fitted for cutting. Good also under glass.

Boutonniere.-Well formed buds and not so large but that it is appropriate for a buttonhole or corsage bouquet.

EDGING.-Makes an excellent edging to a rose-bed or other border.

HEDge.-Adapted for making a hedge, either all one kind or with others.

TREE or STANDARD.-Kinds that do well in tree form, as illustrated on page - .

Note also at the close of this chapter a section devoted to the best roses for each particular purpose in your garden. We feel that entire dependence may be placed upon these recommendations beginning page 64 , based upon the information gained after many years' correspondence with patrons in all parts of the United States.

In a broader way the reader will surely find great interest in cultivating a more intimate acquaintance with this great rose family. Opportunity for further study of this subject is offered in the Analysis of Species and outline of different classes beginning on pages 108 and I 10.

Following these sets for special purposes, and beginning on page 77 , will be found recommendations of the varieties that eminent amateurs, or professionals, have found best adapted to each of eight different typical sections of our country.

But comparatively few people can actually plant more than a small proportion of any such extended list, and therefore we list on the pages immediately following a shorter list of the leading varieties from any of which it will be entirely safe to select. The reader may still have some failures, but they will serve as stepping stones of knowledge surely learned on which to build greater success. 


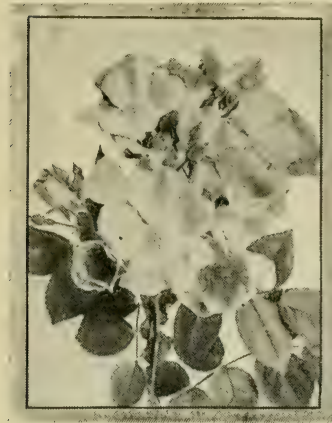

American Pillar

See page 44

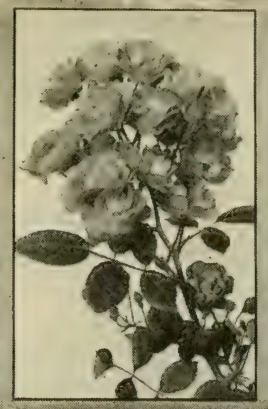

A Baby Rambler See page 44

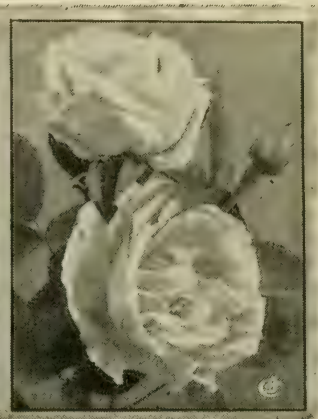

Anna de Diesbach

See page 44

\section{One Hundred Fifty-eight Choice Roses}

Loving roses as we do; living among them and watching them closely and constantly, under all sorts of conditions; having before us reports upon roses from every country on earth to which our roses go, and knowing, too, the prizewinners and kinds that have pleased amateurs here and almost everywhere; watching the new roses as they "come out," testing all kinds and holding fast to those which are good,- - out of an experience like that has come our choice of these 158 roses. See abbreviations, for class, growth, purpose, and pruning, explained on pages 39 to 42 .

ALBERIC BARBIER. W. Flowers in clusters, double, creamy white with canary-yellow center; fragrant. Leaves bronzy red in spring and glossy; almost evergreen, and not liable to be troubled with insects. Very vigorous. Pergola, arch, banks, etc. Prune 6, 7-.

ALEXANDER HILL GRAY. T. Flowers deep Iemon-yellow, which intensifies as the blooms develop; large, of deep substance and perfect formation. Gold Medal, N. R. S. Garden, bedding, cutflower. Prune 4.

ALISTER STELLA GRAY (GoIden Rambler). C.T. Flowers rich apricot-yellow, changing to white with yellow center; delightfully fragrant and constant in bloom. Moderately vigorous. Pillar, pergola, arch, trellis. Needs winter-protection. Prune, 5, $7+$.

AMERICAN BEAUTY, CLIMBING. W. Flowers deep pink to crimson; fragrant. Produces hundreds of perfect blooms at one time. Very vigorous. Pergola, arch, porch, etc. Prune, 6, 7-. 
AMERICAN PILLAR. Mult. Flowers chaste pink; single; large, 3 to 4 inches across; in large clusters. Leaves almost evergreen. Very vigorous. Has attractive, brilliant red hips in autumn. Pergolas, pillar, etc. Prune 6, 7. (See illustration in color, on title-page.)

AMY ROBSART. S.B. Flowers deep rose-pink, beautifully tinted. Leaves deliciously scented. Hedge, pillar, arch, pergola. Vigorous. Prune, 6, 7.

ANNA DE DIESBACH. H.P. Flowers rose; fragrant; profuse. Garden. Prune I for Ex., 3 for Q. (See illustration, page 43.)

ANNE OF GEIERSTEIN. S.B. Flowers crimson. Foliage fragrant. Hedge, pillar, arch, pergola. Vigorous. Prune, 6, 7.

ANTOINE RIVOIRE (H.T). Creamy white to deeper yellow and peachy pink center. Vigorous. Garden and bedding. Prune 3.

ARTHUR R. GOODWIN. H.T. Buds and flowers rich coppery orange-red which shades to salmon-pink as the flower ages; very lasting; blooms large and double. Garden, bedding. Prune 3.

BABY DOROTHY (Maman Levavasseur, or Pink Baby Rambler). P. Flowers bright pink; incessant bloomer, often having 100 to 200 blossoms. Dwarf, 20 in. Bedding, edging. Prune 4. (See illustration in color, page 1 I 7.)

BABY RAMBLER, RED (Mme. Norbert Levavasseur). P. Bright red; dwarf. Bedding, edging. Prune 4 .

BEAUTE DE LYON. Per. Flowers coral-red, slightly shaded with yellow; Iarge and full. Garden, bedding. Prune 4.

BEAUTY OF ROSEMAWR. B. Flowers rich carmine-rose, veined with creamy white. Very floriferous. Garden, bedding. Prune 4.

BIRDIE BLYE. Mult. Flowers bright satiny rose. Continual bloomer. Grows 4 to 6 feet. Pillar, bush. Prune 5.

BLANC DOUBLE DE COUBERT. R. Flowers white, double, Iarge and showy. Very hardy. Vigorous. Hedge, bush. Prune, 5, 7-.

BLANCHE MOREAU. M. Flowers pure white; Iarge and fuII. Bedding. Prune 3.

BRILLIANT. H.T. Flowers brilliant scarlet. Free bloomer. Garden, bedding. Prune 2 .

BRIDESMAID. T. Flowers rose-pink, crimson-shaded; full and fragrant. Bedding, cut-flower. Prune 2 for Ex., 4 for Q. (See illustration in color, page I03.)

CANDEUR LYONNAISE. H.P. Flowers pure white, sometimes tinted with very pale sulphur-yellow. A seedling from Frau KarI Druschki. Vigorous. Garden, bedding. Prune 1 for Ex., 3 for Q.

CECILE BRUNNER (Sweetheart). P. Flowers small and dainty, rosy pink on rich creamy white ground. Very floriferous and deliciously fragrant. Garden, bedding, edging. Prune 5. 


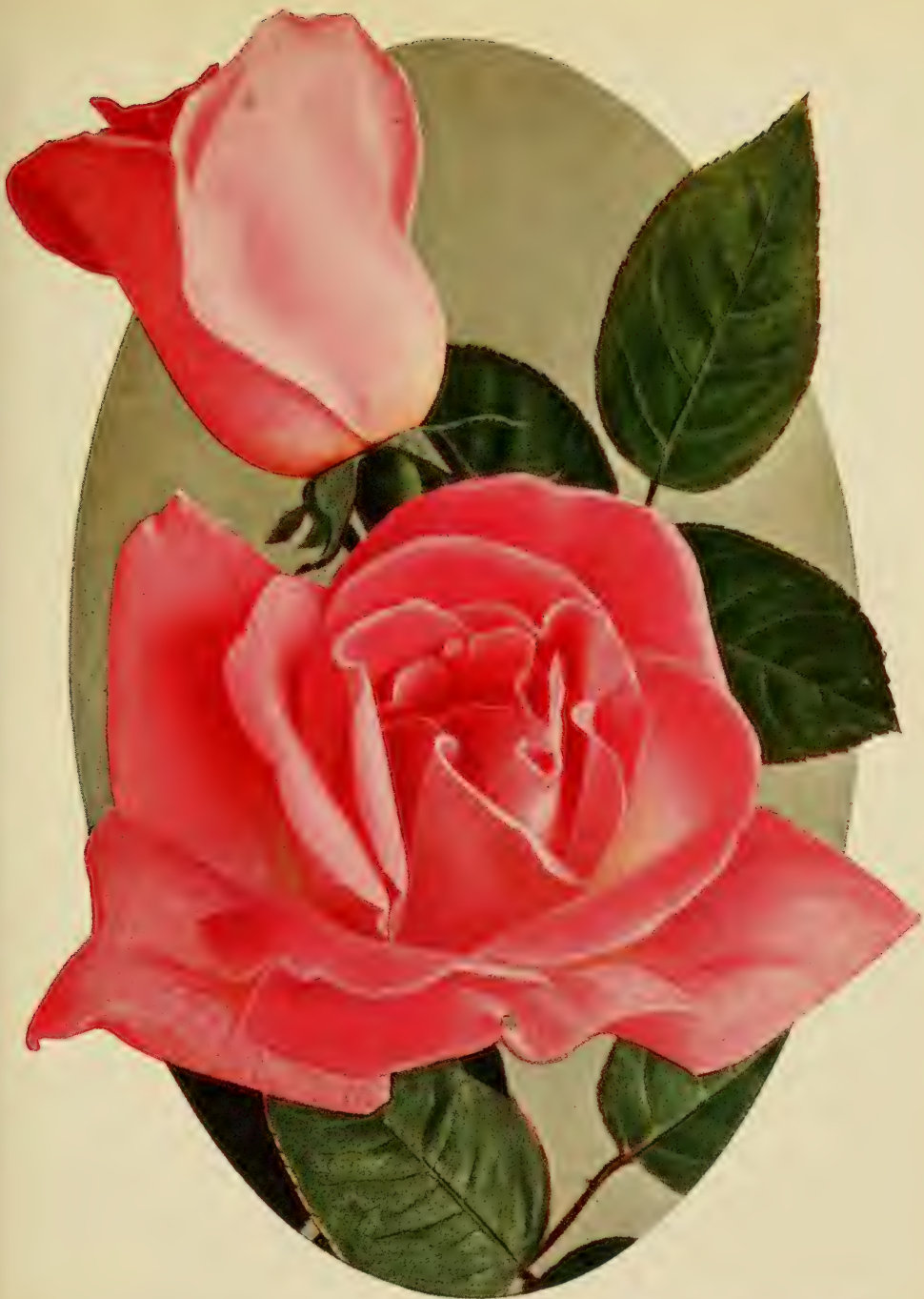

With petals fashioned like sea-shells, tinted and toned in shades of rose and pink, superlatives fail in describing the satisfactory beauty of KILLARNEY, the renowned Hybrid Tea Rose.

Fortunate it is for Rose-lovers that Mother Nature has been so generous in giving us so many members in the Killarney family, all of them rare beauties, such as Killarney Brilliant, Killarney Queen and White Killarney.

For open-ground planting under different conditions of climate, this Killarney Rose family may be depended upon to repay bountifully the attention and care which all Roses should receive. 
CHAMPION OF THE WORLD (Mrs. De Graw). B. Flowers rich, rosy pink; large, full and deliciously sweet. Free bloomer. Garden, bedding. Prune 5 .

CHATEAU DE CLOS VOUGEOT. H.T. Flowers velvety maroon, shaded fiery red, very dark. Garden. Prune 2. (See illustration, page 47.)

CHRISTINE WRIGHT. W. Flowers clear wild-rose-pink; beautiful in bud. Foliage large, thick, leathery. Pillar, arch, arbor, trellis. Prune, 6, 7 。

CLIO. H.P. Flowers flesh-color, shaded pink; large; fine form. Very vigorous. Garden. A very choice variety. Prune I for Ex., 3 for Q.

CONRAD F. MEYER. R. Flowers clear silvery rose; Iarge, perfectly double, elegantly formed; very fragrant. Garden, bush, or hedge. Very hardy. Prune $6+$.

CONSTANCE. Per. Flowers beautiful cadmium-yellow passing to golden yellow. Bud long, orange-yellow streaked with crimson. Foliage glossy. Garden, bedding. Prune 5.

CORONATION. H.P. Flowers shading from flesh to bright shrimppink; immense size. Garden. Prune I for Ex., 3 for Q.

COUNTESS CLANWILLIAM. H.T. Flowers delicate peach-pink at the base of the petals, which are flamed and heavily edged with deep cherry-red. Garden, bedding. Prune 2.

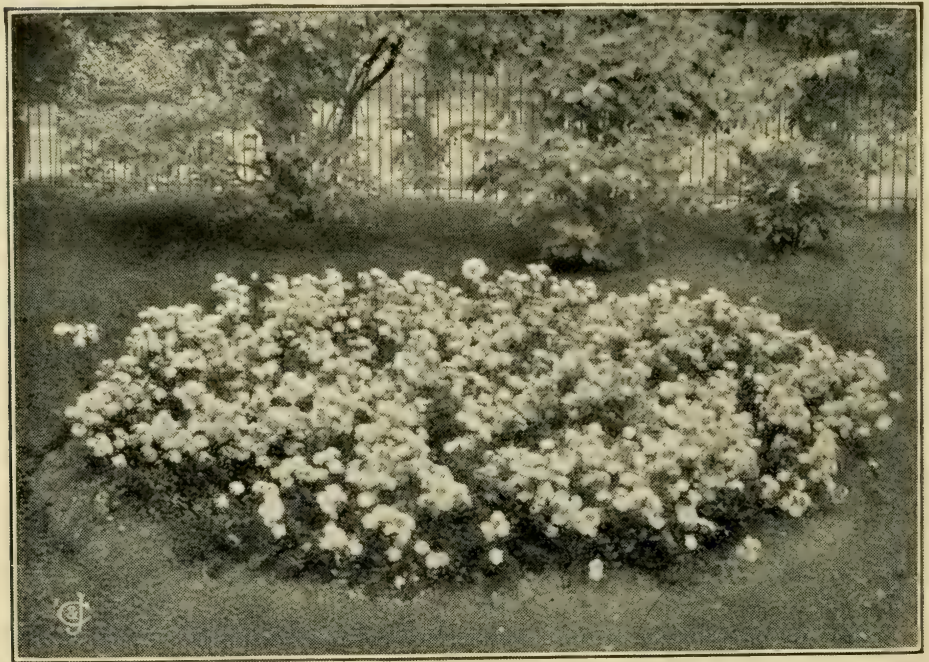

An all-summer show of bloom. An example of what Baby Ramblers will do in a bed 


\section{ROSES FOR AMERICAN GARDENS}

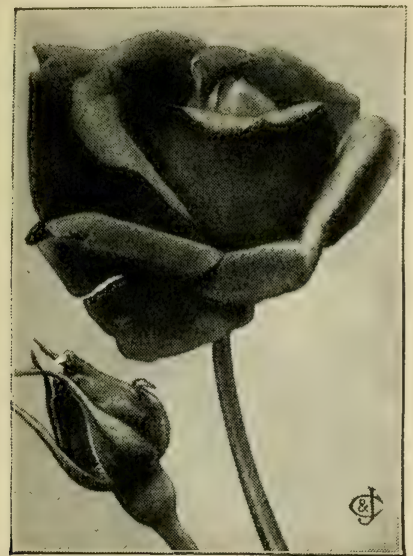

Chateau de Clos Vougeot (see p. 46)

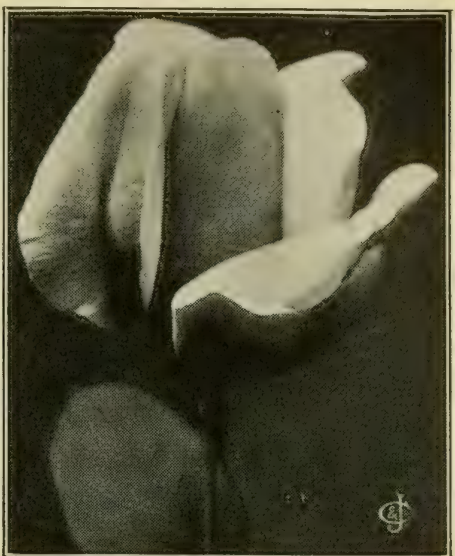

Duchess of Wellington

CRESTED MOSS. M. Flowers choice pink, and heavily mossed. A lovely old favorite. Bedding. Prune 3.

DEVONIENSIS. T. Flowers creamy white with rosy center. Very full. An old-time favorite. Garden, bedding. Prune 2.

DR. W. VAN FLEET. W. Flowers rich flesh-color. Stems i 8 inches long. Choice. Very vigorous. Pergola, arch, etc. Prune 6,7-.

DOROTHY PERKINS. W. Flowers beautifuI shell-pink; freebloomer; large clusters. Most popular rose in its class and color, and blooms in time for use at June weddings. Very vigorous. Arches, porches, pergolas, etc. Prune 6,7-. (Seeillustration in color, page I 2.)

DOROTHY PERKINS, WHITE. W. Flowers snow-white; freebloomer; Iarge clusters. Very vigorous. Habit like Pink Dorothy Perkins. Arches, porches, pergolas, etc. Prune 6, 7-.

DUCHESSE DE BRABANT. T. Flowers deep rosy pink, edged with silver. Has been extensively planted about the White House, at Washington, D. C., a free bloomer. Bedding. Prune 4.

DUCHESS OF WELLINGTON. H.T. Flowers intense saffronyellow. Garden, bedding, cut-flower. Prune 3.

ECARLATE. H.T. Flowers intense dazzling scarlet, semi-double, showing beautiful Iong golden anthers in center. An incessant bloomer. Garden, bedding. Prune 3.

ELLEN POULSEN. T.P. Flowers brilliant pink; fuII, sweet-scented. Very floriferous. Garden, bedding, edging. Prune 3.

ERNA TESCHENDORFF. P. Flowers rich crimson, freely produced. An improved Crimson Baby Rambler. Bedding, edging. Prune 3. 


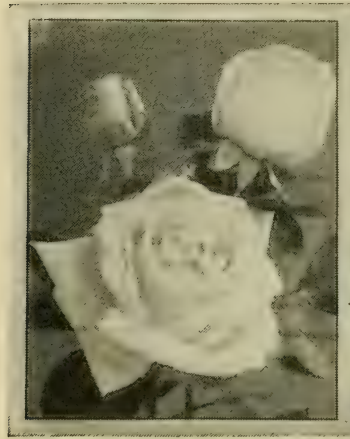

Frau Karl Druschki

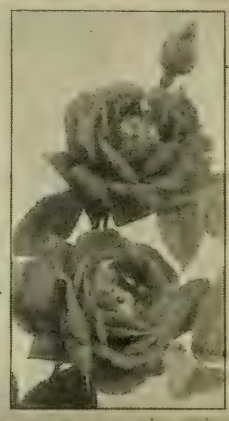

Gen. Jacqueminot

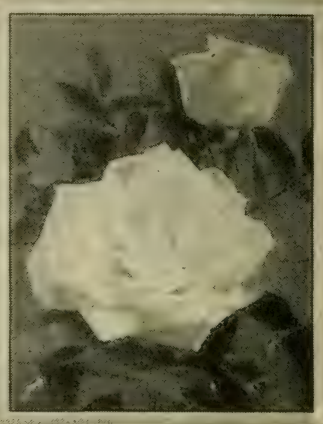

Gloire Lyonnaise See page 49

ETOILE DE FRANCE. H.T. Flowers intense, brilliant crimson; extra-large, double; very free bloomer; fragrant; buds large, pointed. Vigorous. Bedding. A choice variety. Prune 2.

ETOILE DE LYON. T. Flowers bright sulphur-yellow; very double; fragrant. Vigorous. Bedding. Prune 4.

EXCELSA. (Red Dorothy Perkins). W. Iridescent rosy crimson. Very vigorous. Late-flowering. Fine in every way. Arch, porch, trellis, etc. Prune 6, 7-.

FLORENCE PEMBERTON. H.T. Flowers creamy white, suffused pink; large, full, perfect form; high-pointed center. Bush, garden. Prune 2.

FRAU KARL DRUSCHKI (White American Beauty). H.P. Flowers pure snow-white; immense ( 4 to 5 inches across), perfectly double. The finest pure white rose in this class; not fragrant. Vigorous. Bedding, bush, garden. Prune I for Ex., 3 for Q.

GARDENIA. W. Flowers yellow, changing to creamy white; fragrant; free bloomer. Very vigorous; creeping. Prune 6, 7-. (See illustration in color, page 40.)

GENERAL JACQUEMINOT. H.P. Flowers brilliant crimson, velvety; fragrant. Vigorous. Bedding, garden, pot, and standard. Prune 2 for Ex., 3 for Q. (See illustration in color, page 70.)

GENERAL MACARTHUR. H.T. Flowers glowing crimson-scarlet; fragrant. Vigorous. Bedding, garden. Prune 2.

GENERAL-SUPERIOR ARNOLD-JANSSEN. H.T. Flowers deep glowing carmine, large, and freely produced. Garden, bedding. Prune 2.

GEORGE DICKSON. H.T. Flowers velvety dark crimson, back of petals heavily veined with deep, pure crimson-maroon. Garden, bedding. Prune 2. 


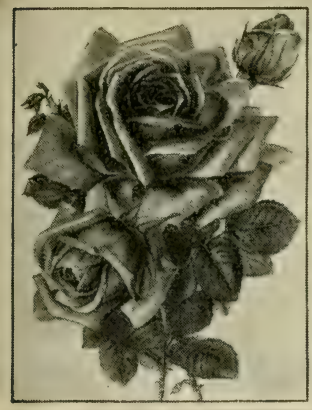

Lyon Rose

See page 52

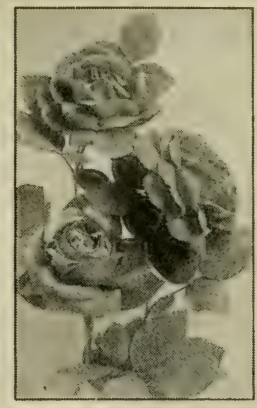

Gruss an Teplitz

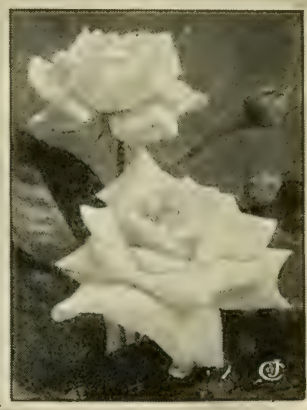

Kaiserin Aug. Victoria See page 50

GLOIRE DE CHEDANE GUINOISSEAU. H.P. Flowers bright vermilion-red with velvety shadings. Choice new variety. Bedding, garden. Prune 2 for Ex., 3 for Q.

GLOIRE LYONNAISE. H.P. Flowers pale lemon; Iarge. Very vigorous. Garden, bedding. A grand rose; the nearest to yellow of any of the Hybrid Perpetuals. Prune 2 for Ex., 3 for Q. (See illustration, page 48.)

GLORY OF MOSSES. M. Flowers blush-color. Very hardy. Bedding. Prune 3.

GRUSS AN AACHEN. P. Flowers flesh-pink and yellow; very double and free-flowering; vigorous. Edging, bedding. Prune 4.

GRUSS AN TEPLITZ. H.T. Flowers bright crimson; free bloomer. Fragrant, hardy, vigorous. Garden, bedding, and bush. Prune 5.

GRUSS AN TEPLITZ, CLIMBING. C.H.T. Flowers bright crimson. Free bloomer; vigorous. Porch, pillar, arch, trellis. Prune 4.

HARISON'S YELLOW. A.B. Flowers intense clear golden yellow. Early bloomer. Very hardy. Bush, hedge. Prune 6.

HARRY KIRK. T. Flowers deep sulphur-yellow with edge of petals lighter; intensely fragrant. Garden, bedding. Prune 2.

HELEN GOOD. T. Flowers delicate pink, shaded deeper pink at the edges; fragrant. Somewhat like Maman Cochet. Garden, bedding. Prune 2.

HENRI MARTIN. M. Flowers bright rosy red; fragrant; Iarge. Free bloomer; vigorous. Fine in its class. Prune 3.

HERMOSA. C. Flowers pink, in clusters; fragrant. Free bloomer; vigorous. Garden, bedding, and standard. Prune 3.

HIAWATHA. W. Flowers brilliant scarlet; single; bright and effective. Vigorous. Arch, trellis, etc. Prune 6, 7-. 
HOOSIER BEAUTY. H.T. Flowers glowing crimson; one of the richest-colored roses in cultivation; large, full, and deliciously sweet. Garden, bedding, cut-flower. Prune 3.

HUGH DICKSON. H.P. New. Flowers brilliant crimson, shaded scarlet; very large and fuII; fine form. Free-flowering and vigorous. Highly perfumed. Garden. Prune I for Ex., 3 for Q.

HUGO ROLLER. T. Flowers lemon-yellow and crimson. A teascented "pictorial” flower. Garden, bedding. Prune 2 for Ex., 4 for Q.

IRISH ELEGANCE. H.T. Flowers bronzy orange-scarlet in the bud stage, which assumes apricot hues as the flower opens; large, single variety. Garden, bedding. Prune 2. (See illustration page 75.)

J. B. CLARK. H.P. Flowers intense, scarlet, shaded crimson. Vigorous. Garden, bedding. Prune 2 for Ex., 3 for Q. (See illustration in color, page 21 .)

JONKHEER J. L. MOCK. H.T. Flowers carmine on the outside, Iovely soft pink inside; large; full, fine form and fragrant. Garden, bedding, cut-flower. Prune 2.

JOSEPH HILL. H.T. Flowers pure salmon and gold, outside of petals pinkish copper. Garden, bedding. Prune 2.

JULIET. Per. Flowers old-gold on the outside while the inside is rosy red, changing to deep rose as the flowers expand. Large, full, and delightfully fragrant. Garden, bedding. Prune 4.

KAISERIN AUGUSTA VICTORIA. H.T. Flowers white, shading to Iemon; deep; full; fragrant. Free bloomer; vigorcus. Garden; also cut-flower. Cannot be too highly recommended. Prune 3.

KILLARNEY. H.T. Flowers brilliant pink; long, pointed buds. Free bloomer; moderately vigorous. Garden, bedding, cut-flower. A great favorite. Prune 3. (See illustration in color, page 45.)

KILLARNEY BRILLIANT. H.T. Flowers larger, more double, and a deeper pink than the parent Killarney; fragrant. A free bloomer. Garden, bedding, cut-flower. Prune 3.

LADY ALICE STANLEY. H.T. Flowers deep coral-rose and pale flesh, large, exceptionally full, very lasting when cut. Garden, bedding, cut-flower. Prune 3.

LADY HILLINGDON. T. Flowers deep apricot-yellow, shading to orange. Garden, bedding, cut-flower. Prune 2. (See illustration, page 52.)

LADY MARY WARD. H.T. Flowers rich orange, shaded deeper orange with metallic veneering. Garden, bedding. Prune 2.

LADY PENZANCE. S.B. Flowers soft coppery color. Lord Penzance Hybrid. Leaves deliciously scented. Hedge, pillar, arch, porch. Prune 6, 7-.

LA FRANCE. H.T. Flowers silvery rose, changing to pink; fine form; sweet; large; lovely buds. Moderately vigorous. Garden, bush, standard, and cut-flower. Prune 2. (See illustration, page 53.)

LA TOSCA. H.T. Flowers rose. Free bloomer; good vigorous. Garden, bush, bedding. Prune 2 for Ex., 4 for Q. 


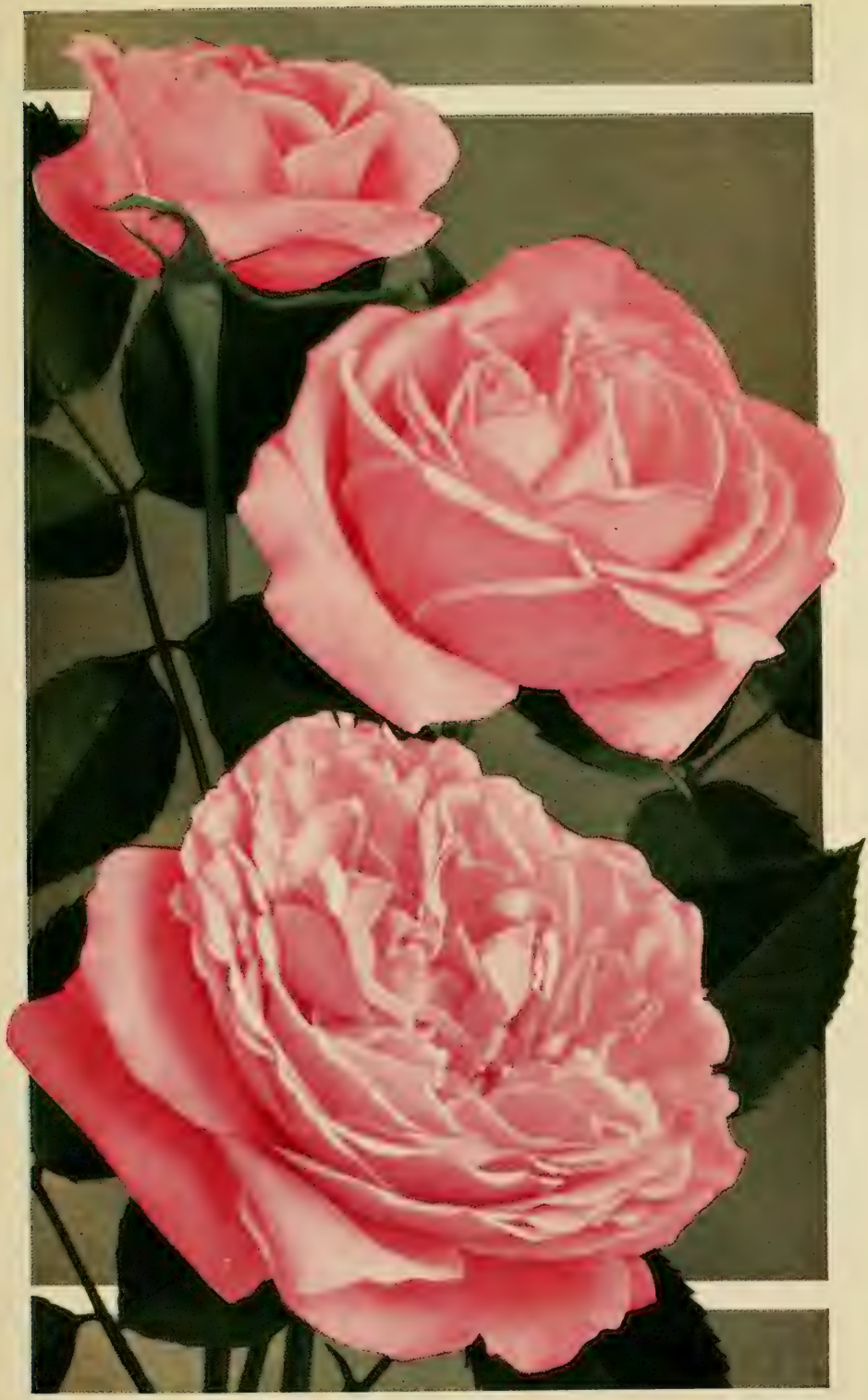

Among the pink Hybrid Perpetual Roses, MRS. JOHN LAING stands well in the lead, - not so large as Paul Neyron, but more free in bloom, with excellent form, clear color and rich fragrance. 


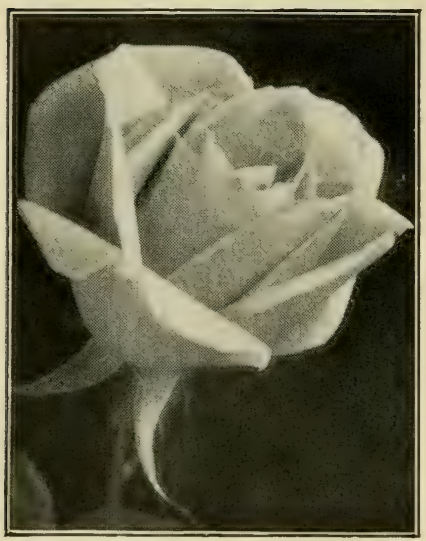

Lady Hillingdon (see page 50)

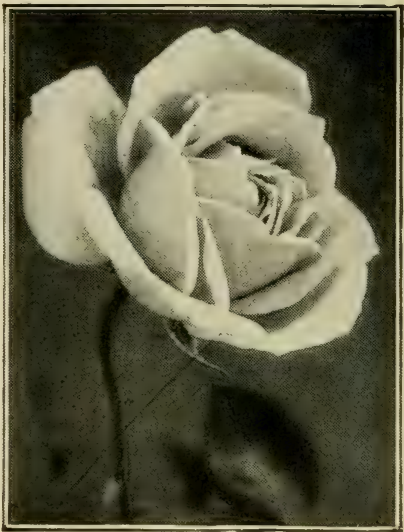

Mme. Camille

LAURENT CARLE. H.T. Flowers brilliant, velvety carmine; large and perfect; intensely fragrant. Garden, bedding. Prune 2.

LEONIE LAMESCH. P. Flowers vary from cochineal-red in the bud to glowing coppery red, marked with orange when the bloom opens. Very floriferous. Garden, bedding. Prune 3.

LOUISE CATHERINE BRESLAU. Per. Flowers shrimp-pink, shaded with reddish coppery orange and chrome-yellow on the reverse of petals. Garden, bedding. Prune 5.

LOUISE WELTER (Baby Tausendschön). P. Flowers deep pink to white. Identical in color with the popular climbing Tausendschön, or Thousand Beauties. Bedding, edging. Prune 5.

LYON ROSE. H.T. Flowers salmon-pink shaded chrome-yellow; full; globular; fragrant. Vigorous. Hardy. Bedding. Constant bloomer. Said to be beyond competition. Prune 3. (See illustration, page 49.)

MME. ALFRED CARRIERE. N. Flowers cream-white, tinged pale yellow. Large, full, double, and sweet. Vigorous grower. Porch, arch, trellis. Prune 7.

MME. CAMILLE. T. Flowers flesh, changing to salmon; Iarge, fuII; sweet. Constant bloomer; vigorous. Bedding. Prune 2.

MME. CAROLINE TESTOUT. H.T. Flowers clear pink, edged silvery rose. Magnificent variety. Garden, bedding. Prune 2. (See illustration in color, page $\mathrm{I} 2$.)

MME. CHARLES LUTAUD. H.T. Flowers deep chrome-yellow, sometimes tinged rosy scarlet. Garden, bedding. Prune 2.

MME. EDMOND ROSTAND. H.T. Flowers pale flesh, shaded with salmon, center reddish orange-distinct and charming. Garden, bedding. Prune 5. 


\section{ROSES FOR AMERICAN GARDENS}

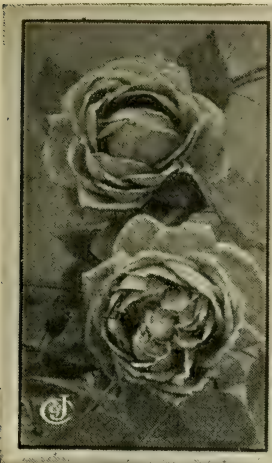

Magna Charta

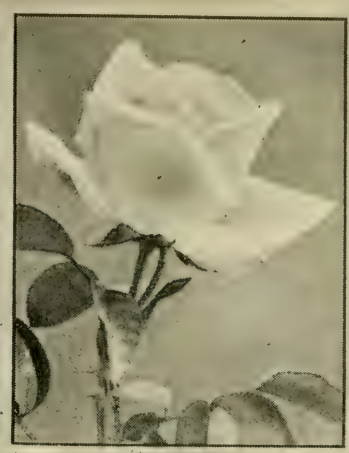

Killarney

See page 50

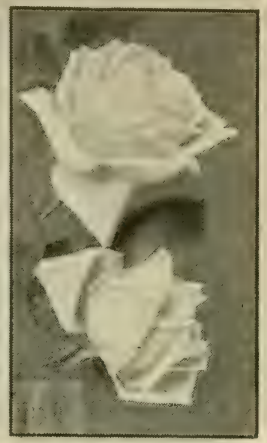

La France

MME. EDOUARD HERRIOT (The Daily Mail Rose). Per. The most unique variety, recently introduced. Flowers medium size, semi-double, superbly colored, coral-red shaded with yellow and bright rosy scarlet, passing to prawn-red. Garden, bedding. Prune 5.

MME. EUGENE MARLITT. B. Flowers carmine-red; fragrant; free bloomer. Vigorous. Bedding. Prune 4, tip severely.

MME. JULES GROLEZ. H.T. Flowers china rose, passing to clear, rich satiny pink. Garden, bedding. Prune 2. (See illustration, page 59.)

MME. LEON PAIN. H.T. Flowers silvery saImon, center orangeyellow. Garden, bedding. Prune 2.

MME. MELANIE SOUPERT. H.T. Flowers salmon-yellow, suffused carmine; fragrant. Free bloomer. Garden, bedding. Prune 2.

MME. RAVARY. H.T. Flowers rich orange-yellow. Free-blooming and deliciously fragrant. Garden, bedding. Prune 2.

MME. SEGOND WEBER. H.T. Flowers salmon-flesh-color; deep pink when opening. Garden, bedding. Prune 2.

MADISON. T. Flowers creamy white, sometimes tinged pink; similar to "Bride" in form but superior to it; deliciously fragrant. Garden, bedding. Prune 2 for Ex., 4 for Q.

MAGNA CHARTA. H.P. Flowers pink, suffused with carmine; extra large; fuII; fragrant. Free bloomer. Leaves light green. Vigorous. Bedding. A choice variety. Prune 2 for Ex., 3 for Q. (See cut.)

MAMAN COCHET. T. Flowers flesh-pink suffused light rose; large, double, fragrant. Fine. Vigorous. Garden, bush. Prune 2.

MAMAN COCHET, PINK, CLIMBING. C.T. New. Flowers like those of Maman Cochet. Porch, pergola, arch, etc. Prune 4. 


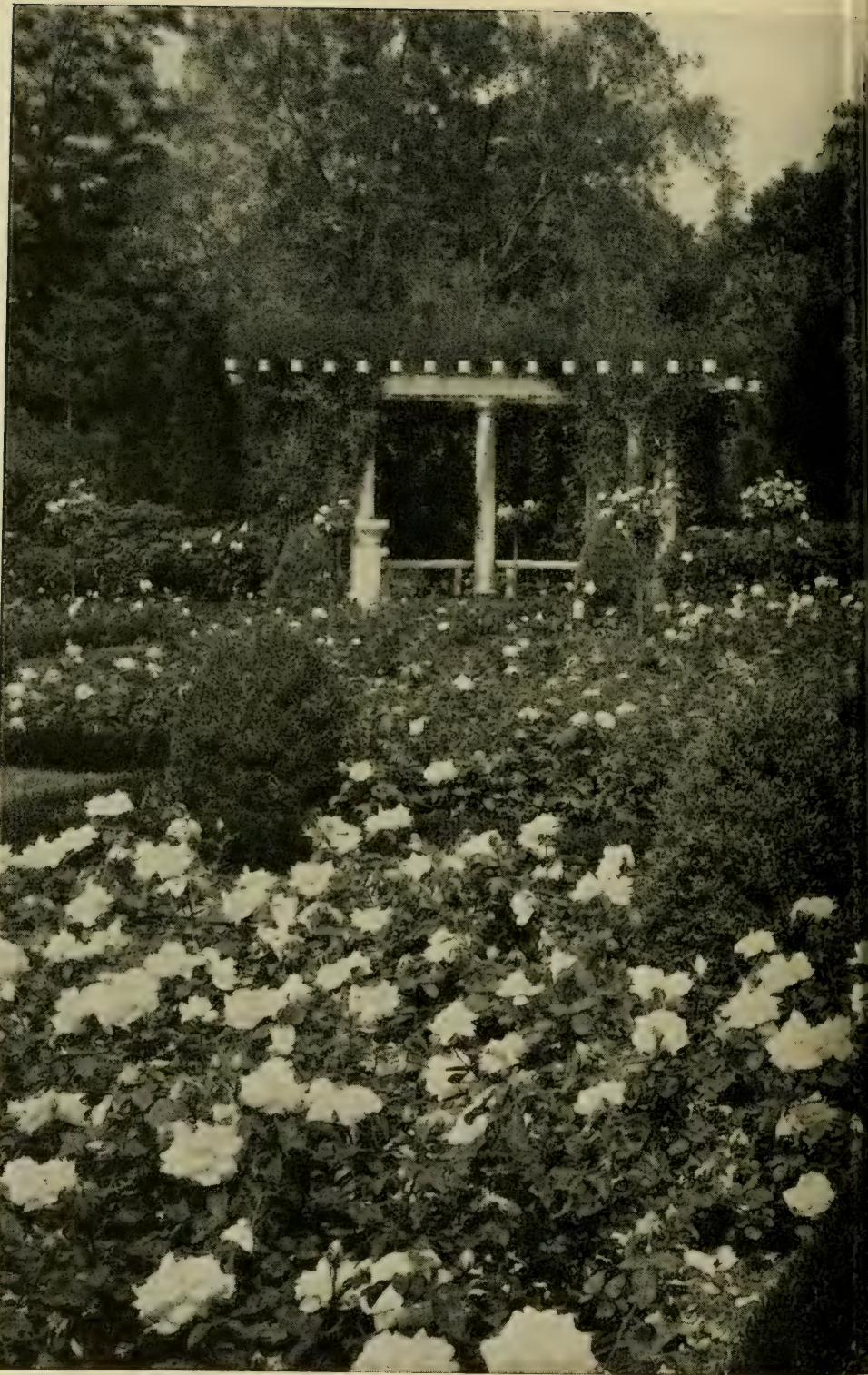




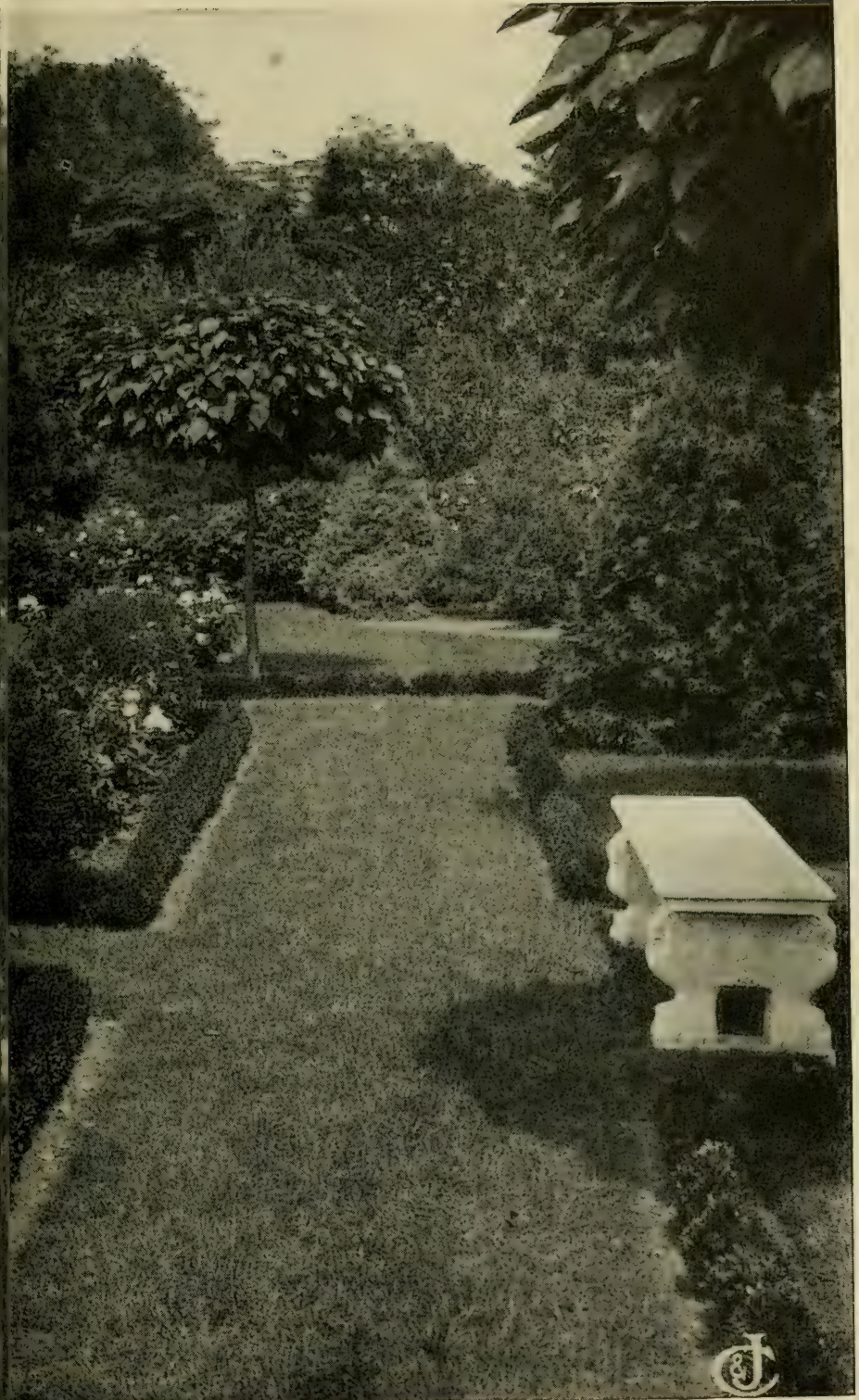




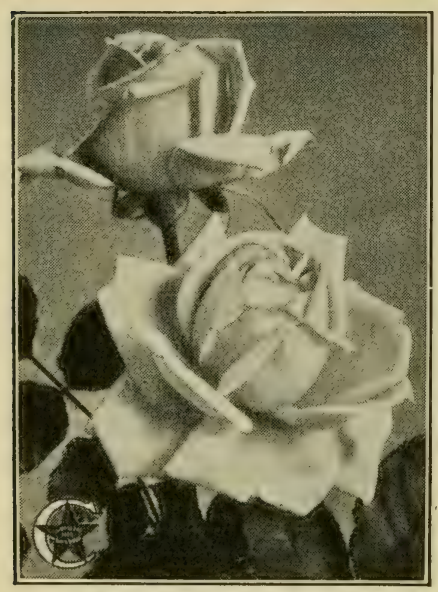

Miss Alice de Rothschild See page 57

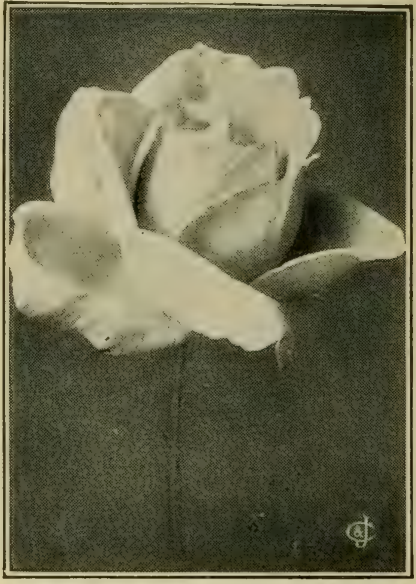

Mrs. Wakefreld Christie Miller See page 57

MAMAN COCHET, WHITE. T. Flowers snow-white, with outside petals tipped pink in the autumn. Large and fragrant. Garden, bedding, boutonniere. Prune 2.

MARECHAL NIEL. N. Flowers deep yellow; Iarge; globular; full; sweet. A most beautiful climber. Hardy only in the South. Vigorous. Porch, pillar, pot, standard, etc. Prune 5.

MARGARET DICKSON HAMILL. H.T. Flowers delicate strawcolor, edge flushed with carmine. Fragrant. Garden, bedding. Prune 2.

MARIE GUILLOT. T. Flowers pure snowy white, Iarge and full. Very fragrant. Garden, bedding. Prune 2.

MARIE PAVIE. P. Flowers white with delicate rose center. Unsurpassed as a bush cemetery rose. Blooms unceasingly and is quite hardy. Garden, bedding. Prune 3.

MARIE VAN HOUTTE. T. Flowers pale yellow, edged with rose; large; full; fragrant. Constant bloomer; vigorous. Bedding. Prune 2.

MARQUISE DE SINETY. H.T. Buds rich yellow-ocher suffused with carmine. The expanded flower is yellow, shaded rosy red. Garden, bedding. Prune 2.

MARY, COUNTESS OF ILCHESTER. H.T. Flowers beautifuI crimson-carmine; very large and double. Garden, bedding. Prune 2.

MARY LOVETT. W. Flowers pure pearly white; same type as the beautifuI Dr. W. Van Fleet. Pergola, arch, etc. Prune 6, 7-.

MAY QUEEN. W. Flowers clear bright pink and de!iciously sweet. A great bloomer. Pergola, arch, pillar, bush, hedge. Prune 6. 


\section{ROSES FOR AMERICAN GARDENS}

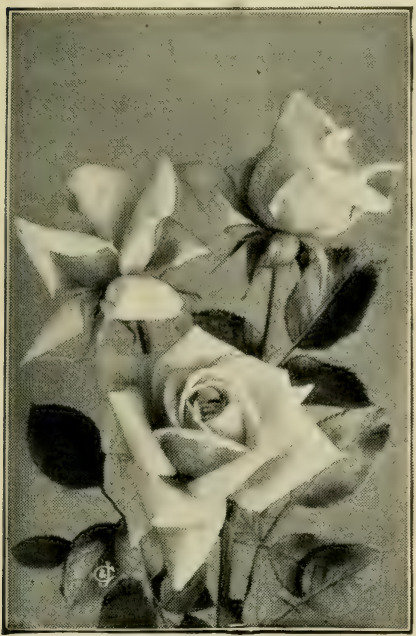

Mrs. Aaron Ward

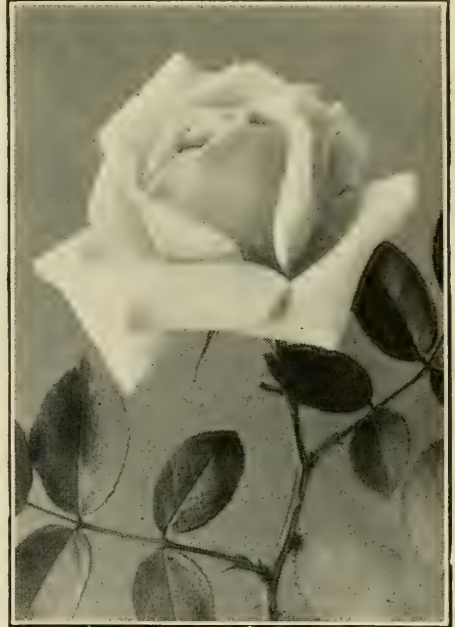

Miss Cynthia Forde

MISS ALICE DE ROTHSCHILD. T. Flowers rich yellow. We caII it bush Marechal Niel, although it is hardier. Garden, bedding. Prune 2. (See illustration, page 56.)

MISS CYNTHIA FORDE. H.T. Flowers deep brilliant rose-pink. Sweetly perfumed. Garden, bedding. Prune 2.

MOLLY SHARMAN-CRAWFORD. T. Flowers delicate white, passing to pure white. Garden, bedding. Prune 2.

MRS. AARON WARD. H.T. Flowers Indian yellow, sometimes tinged salmon-rose. Garden, bedding; boutonniere. Prune 2.

MRS. A. R. WADDELL. H.T. Flowers coppery red suffused with salmon. Incessant bloomer. Garden, bedding. Prune 2.

MRS. B. R. CANT. T. Flowers rose-red; Iarge, fulI, perfectly double; fragrant. Constant bloomer; vigorous. Garden, bedding. Prune 3.

MRS. HERBERT STEVENS. T. Flowers white with center shaded fawn and peach. Garden, bedding. Prune 2.

MRS. JOHN LAING. H.P. Flowers soft pink; large, fuII; fragrant. Free bloomer; vigorous. Garden, bedding. Prune I for Ex., 3 for Q. (See illustration in color, page $5 \mathrm{I}$.)

MRS. WAKEFIELD CHRISTIE MILLER. H.T. Flowers soft pearly blush. Garden, bedding. Prune 2. (See cut, page 56.)

MURIEL DICKSON. Per. Flowers deep reddish copper in the bud state paling with age to cherry-red with coppery shadings. Garden, bedding, cut-flower. Prune 4 . 

MY MARYLAND. H.T. Flowers lovely salmon-pink, very freely produced on long stems. Garden, bedding, cutting. Prune 2.

NEW CENTURY. R. Flowers clear flesh-pink with light red center; deliciously sweet; fragrance like the wild rose. Extremely hardy. Hedge, bush, or garden. Prune 6.

OPHELIA. H.T. Flowers salmon-flesh-color, shaded with rose. Garden, bedding, cut-flower. Prune 2.

ORLEANS. P. Flowers vivid rosy crimson. Garden, bedding, edging. Prune 3.

PAUL NEYRON. H.P. Flowers deep rose; fragrant; opens flat. Vigorous. Bedding, garden. Prune I for Ex., 3 for Q.

PERLE DES JARDINS. T. Flowers deep yellow; very large, fuII, and fragrant. Garden, bedding. Prune 2. (See illustration in color, page 32.)

PERSIAN YELLOW. A.B. Flowers deep, rich, golden yellow. Garden, bush, hedge. Prune 6. (See illustration in color, page 63.)

PHILADELPHIA RAMBLER. Mult. Flowers intense crimson; double; in Iarge clusters. Very vigorous. Arch, porch, etc. Hardy. Prune 6-, 7 t.

PRINCE CAMILLE DE ROHAN. H.P. Flowers velvety crimson; Iarge. Vigorous. Bedding. Prune 2 for Ex., 3 for Q.

PRINCESS ADELAIDE. M. Flowers bright rosy pink, beautifully mossed; double and sweet. Garden, bedding. Prune 3.

QUEEN'S SCARLET. C. Flowers rich velvety scarlet, size mediu m. Constant in bloom. Garden, bedding. Prune 3.

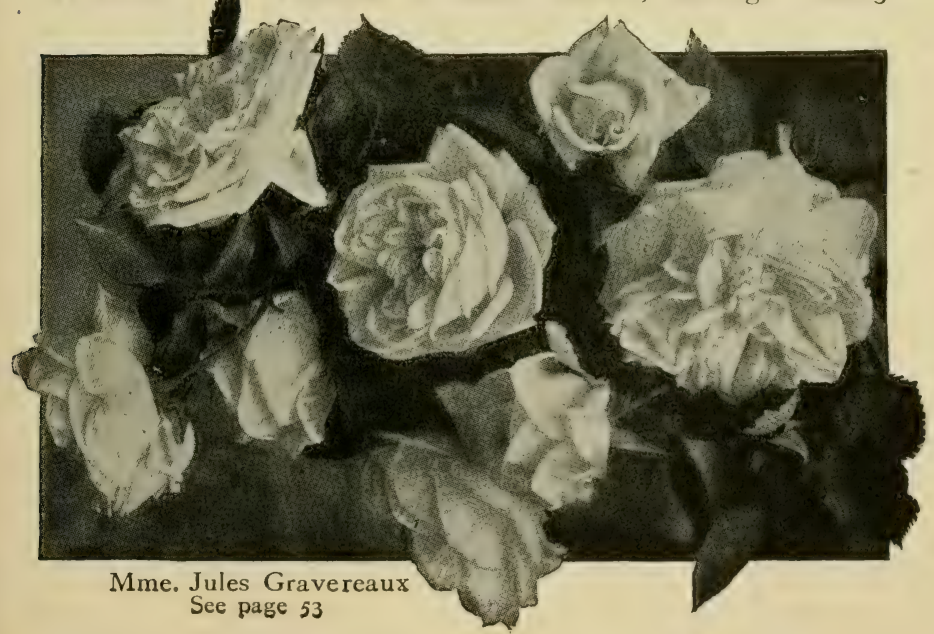




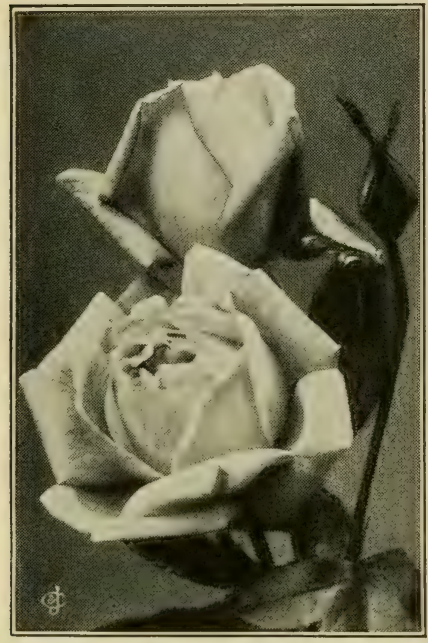

Rayon d'Or

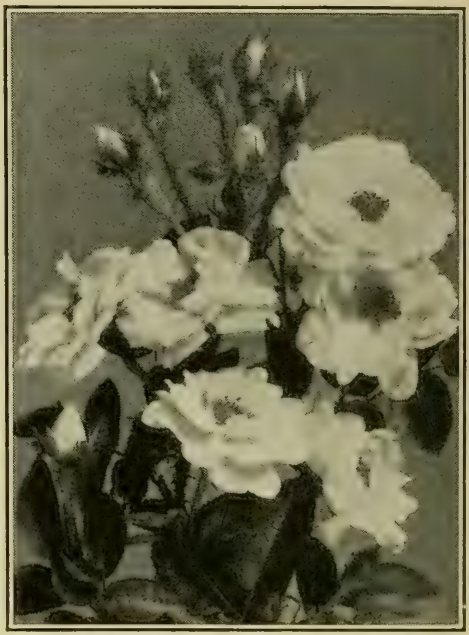

Wichmoss (see page 62)

RADIANCE. H.T. Flowers rosy carmine and pink; fine for mass planting. Garden, bedding. Prune 2.

RAYON D'OR. Per. Flowers cadmium-yellow as they begin to open, toning to sunflower-yellow when fully expanded. Garden, bedding. Prune 2.

RHEA REID. H.T. Flowers rich red; very double; fragrant. Garden, bedding. The "Grand Prize Rose" of Paris for I908. Prune 3. (See illustration, page 6r.)

ROGER LAMBELIN. H.P. Flowers glowing crimson with pure white around the edge of each petal. Unique. Garden, bedding. Prune I for Ex., 3 for Q. (See illustration in color, page I I 2.)

ROSERAIE DE L'HAY. R. Flowers bright red and intensely fragrant; free bloomer. Hedge, bush, or garden. Prune 5, $7+$.

RUGOSA ALBA. R. Flowers single, pure white, five petals; highly scented. Makes pretty red berries which last well into winter. Hedge, bush. Prune 6. (See illustration in color, page 87.)

RUGOSA RUBRA. R. Flowers single, bright rosy crimson; highly scented. Large red berries. Hedge, bush. Prune 6.

SAFRANO. T. Flowers apricot-yellow; fragrant; semi-double. Constant bloomer; vigorous. Bedding, garden. Prune 3.

SILVER MOON. W. Flowers very Iarge, single, brilliant silvery white with a mass of golden yellow stamens in center. Vigorous. Creeping. Prune 6, 7-. 


\section{ROSES FOR AMERICAN GARDENS 6I}

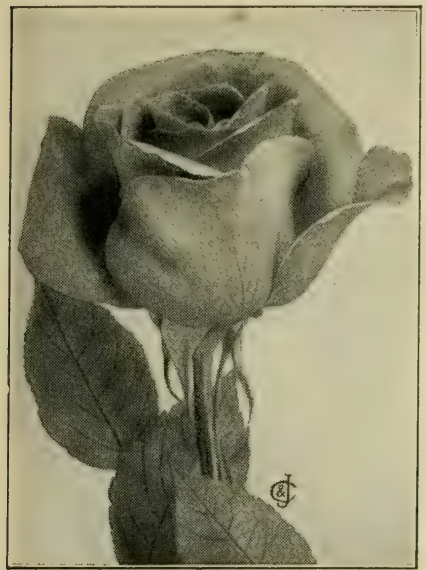

Rhea Reid (see page 6o)

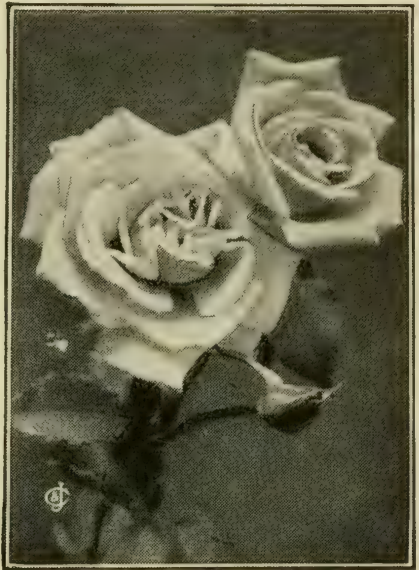

Taft Rose

SIR THOMAS LIPTON. R. Flowers pure white; fragrant; constant bloomer. Leaves beautiful. Vigorous. Hedge, bush, or garden. Very hardy. Prune 5, $7+$.

SOLEIL D'OR. (Sun of Gold.) Per. Flowers reddish gold, orange-yellow, nasturtium-red, and rosy pink. Spicy orange fragrance. Garden, bedding. Prune 4 .

SOUV. DE GUSTAV PRAT. H.T. Flowers clear light sulphur-yellow. Garden, bedding. Prune 2.

SOUV. DE LA MALMAISON. B. Flowers Iovely creamy flesh with rose center, elegantly shaded. Garden, bedding. Prune 3.

SOUV. DE PIERRE NOTTING. T. Flowers apricot-yellow, shaded orange. Garden, bedding. Prune 2.

SUNBURST. H.T. Flowers intense orange-copper and golden yellow. Extra fine. Garden, bedding. Prune 2.

SUNRISE. T. Flowers peachy red, beautifulīy shaded with orange and crimson; especially good in the South. Garden, bedding. Prune 2.

SWEETBRIAR ( $R$. rubiginosa). S.B. Flowers pink; single. Vigorous. Hedge, bush. Foliage delightfully fragrant. Prune $6,7+$.

TAFT ROSE. H.T. Flowers rich salmon-pink shaded at the base with chrome-yellow. Profuse bloomer. Garden, bedding. Prune 2.

TAUSENDSCHÖN. MuIt. Flowers white to deep pink. Very vigorous. Porch, arch, etc. Has few thorns. Fine. Prune 6, 7-. (See illustration in color, page 78.) 


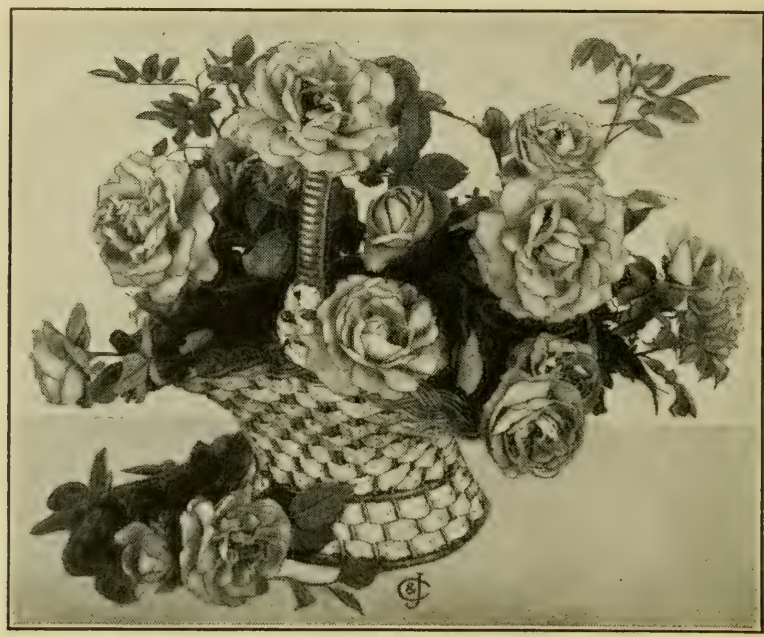

A tasteful arrangement of Ulrich Brunner roses

ULRICH BRUNNER. H.P. Flowers rich red; fragrant; petals broad, round, thick. Vigorous. Garden, bedding, and standard. A standard variety. Prune I for Ex., 3 for Q. (See illustration in color, page 94.)

WHITE KILLARNEY. H.T. Flowers pure white; Iong, pointed buds. Vigorous. Garden, bedding, cut-flower. Prune 3.

WICHMOSS. (The Climbing Moss Rose.) W. Flowers light pink, reverse of petals darker. Very hardy. Pillar, arch, pergola, trellis. Prune 7. (See illustration, page 6o.)

WICHURAIANA. W. Flowers pure white; single. Leaves glossy, free from insects. Will grow anywhere. Splendid for holding banks from washing. Vigorous. Creeping. Prune 6, $7+$.

WILLIAM ALLEN RICHARDSON. N. Flowers coppery yellow, tinged with carmine; deliciously fragrant. Not hardy. Splendid for the South. Vigorous. Porch, pillar. Prune 5.

WM. R. SMITH. T. Blush-pink; Iarge; full. Vigorous grower. Garden, bedding. Prune I for Ex., 3 for Q.

WILLIAM SHEAN. H.T. Flowers pure pink with delicate ochery venation; very large. Vigorous. Bedding, garden. Prune 3.

WILLOWMERE. H.T. Flowers rich shrimp-pink, shaded yellow in the center. Garden, bedding. Prune 4.

YORK AND LANCASTER. Damask. Flowers striped red and white. Very hardy. A very old and rather rare rose. Associated with the "Wars of the Roses." Garden. Prune 4. (See illustration, page 7.) 


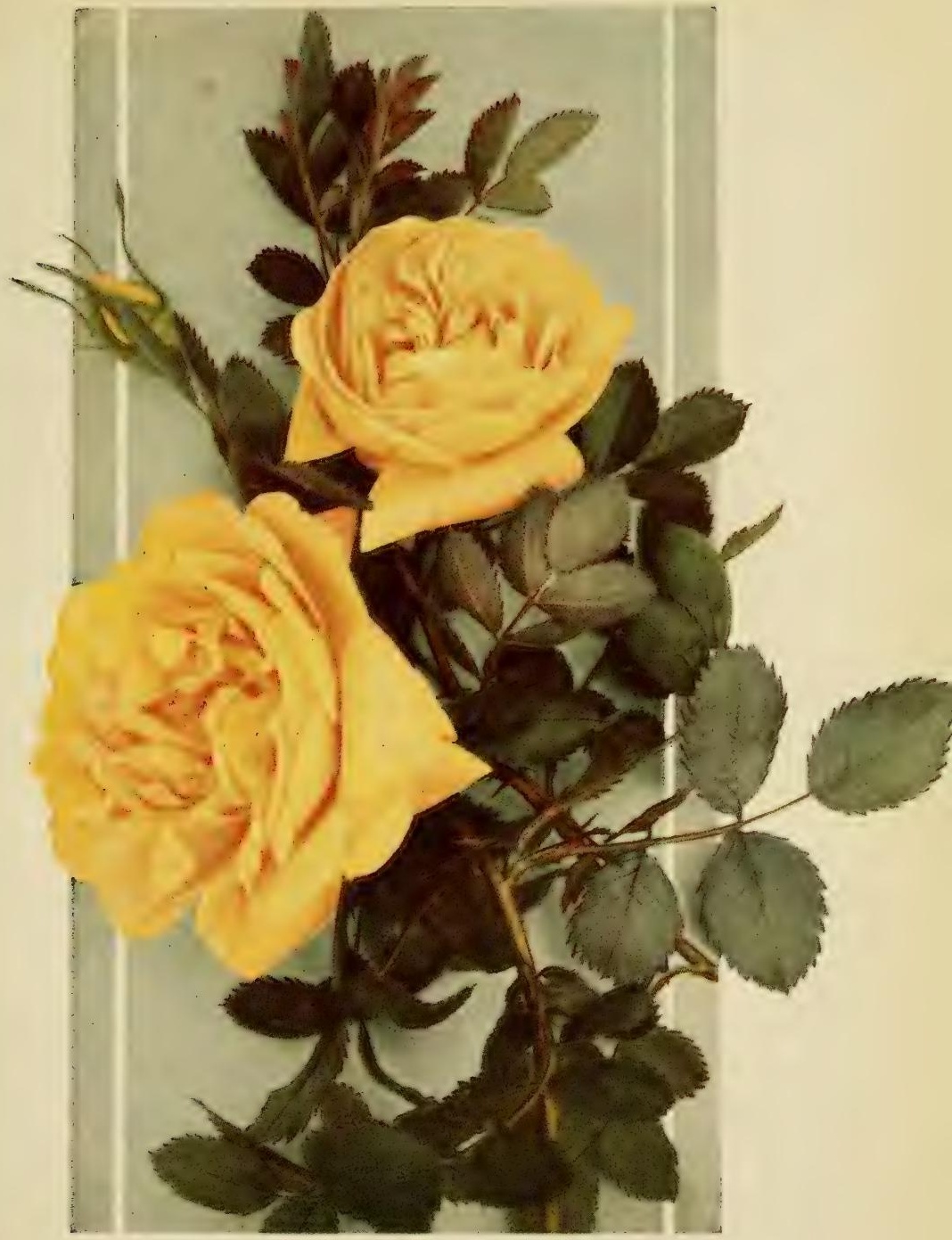

The beautiful PERSIAN YELLOW Rose is commended highly, especially to those living in the colder sections of our country.

Its rich coloring and hardiness, combined with its early season of bloom and fragrant young foliage, give it a value among Roses comparable to the value of gold among metals.

It blooms brilliantly and abundantly, though not continually; and, above all, it is so hardy as to stand severe winters, without protection, almost anywhere. 


\section{HOW TO GROW ROSES}

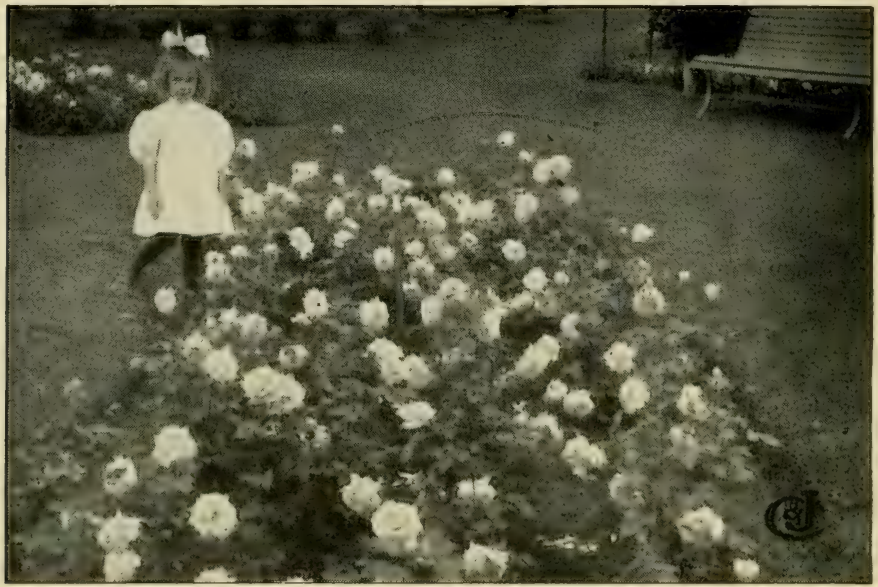

La France. Beautiful on the lawn; just as fine in vases

\section{Roses for Various Purposes and Uses}

\section{Twelve Star Varieties}

In selecting the best roses, there are so many qualities to be considered that it requires a large collection and unusual opportunities to watch and study them under every possible condition they are likely to encounter. We have been fortunate in having unusual facilities for this experimental work. Furthermore, our observation extends over a long period of years, during which, each season, we have obtained and tried out all new sorts of promise, and thus aim to have the best obtainable constantly on trial. We also travel extensively and visit rose-gardens in many states of the Union. Due regard has been given to the published experiences of other dependable rose-lovers, in reaching our own conclusions.

To pass our severe test, a rose must prove itself a vigorous grower and an abundant bloomer, and must also excel its rivals either in size, color, form, fragrance, or habit.

So many friends ask us to select their roses that we believe they must have read Pemberton's advice: "State your 
requirements to a friend who is an expert, and leave the selection to him." These pages answer your questions before you ask them; they save you the expense of experiments; and, if you do your part, you can count on a reward of good bloom.

Frau KarI Druschki. (H.P.)

Kaiserin Augusta Victoria. (H.T.)

White Maman Cochet. (T.)

Coronation. (H.P.) Pink.

Paul Neyron. (H.P.) Pink.

Wm. R. Smith. (T.) Pink.

Jonkheer J. L. Mock. (H.T.)

Sunburst. (H.T.) Yellow.

Hugh Dickson. (H.P.) Red.

Prince Camille de Rohan. (H.P.)

Gruss an Teplitz. (H.T.) Red.

Mme. Eugene Marlitt. (B.C.) Red.

\section{Twelve Cold Country Roses}

Here are roses selected from among those that live outdoors over winter and thrive in localities north of the latitude of New York and Chicago. These laugh at zero weather. White and LightPage Pink, continued -

Frau Karl Druschki. (H.P.). 48

Sir Thomas Lipton. (H.R.) . 6 I

Conrad F. Meyer. (H.R.). . 46

Gloire Lyonnaise. (H.P.).. . 49 Pink-

Paul Neyron. (H.P.). . . 59

Coronation. (H.P.). . . . 46

May Quene (H.C.) Page

May Queen. (H.C.) . . . 56

Willowmere. (H.T.).... .62 Red-

Hugh Dickson. (H.P.).. . . 50

Roseraie de I'Hay. (H.R.)...60

Ulrich Brunner. (H.P.). . . 62

Gloire de Chedane Guinois-

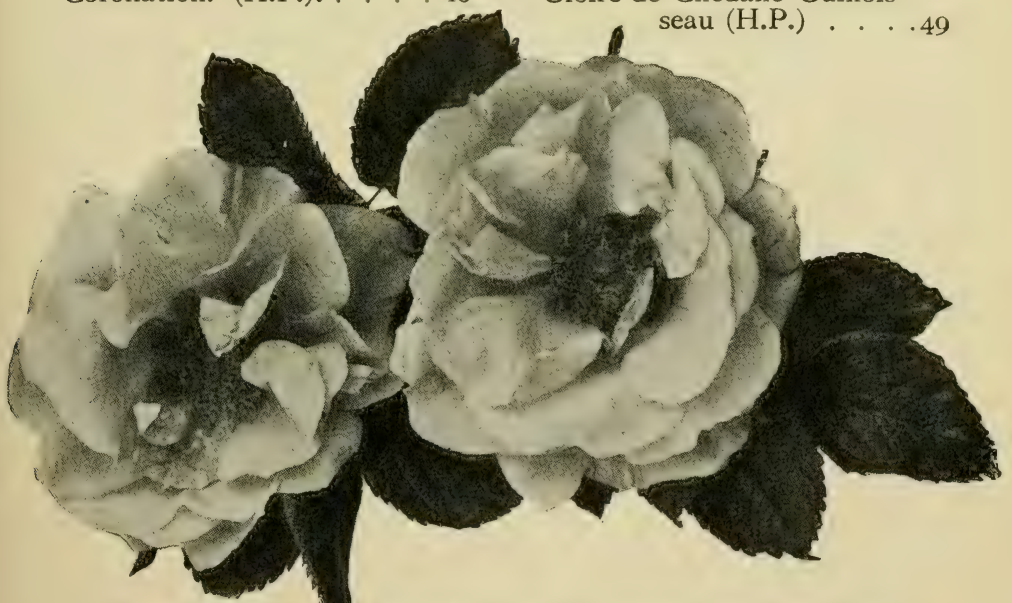

Hybrid Rugosas.

Invaluable for cold country planting. Note the beautiful foliage 


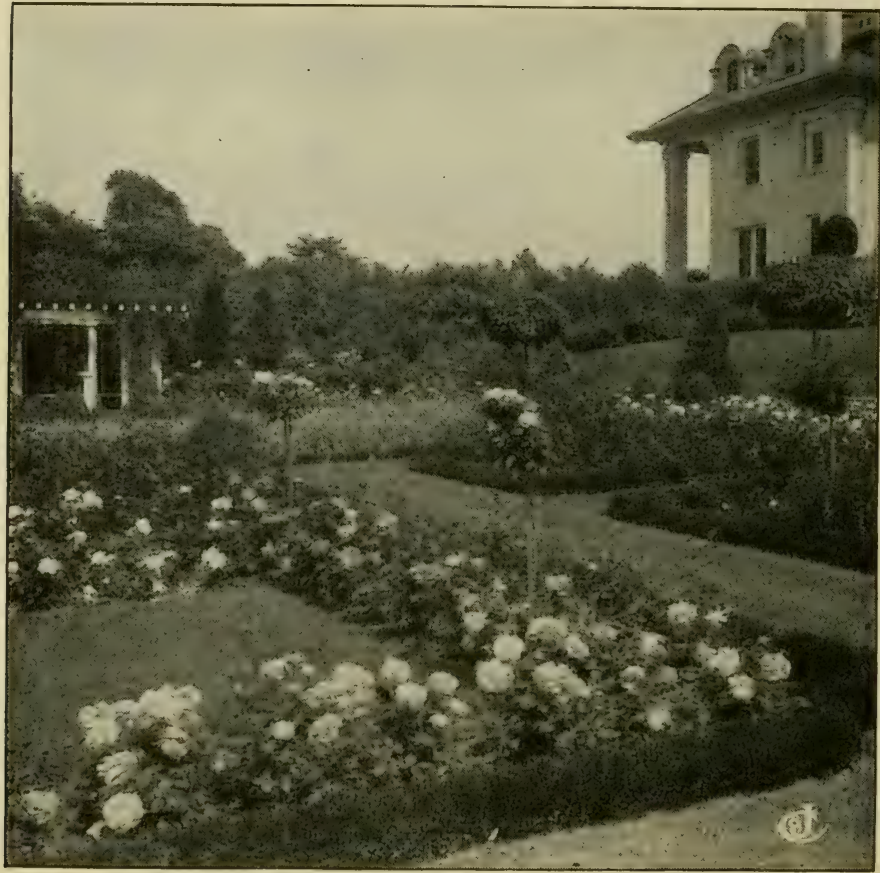

Nearly every home may have a dozen bushes like these

\section{Twelve Sunny South Roses}

If you live on the sunny side of the frost-line and wish a set of superior sorts for a warm country, here are twelve that we know you will find supremely satisfying.

These are our favorite twelve in a climate where there is little danger from frost. They will winter well as far north as Washington, D. C.

Yellow-

Etoile de Lyon. (T.) . . . . 48

Duchess of Wellington. (H.T.) 47

Safrano. (T.).... . . 6o

Sunburst. (H.T.) . . . 6I Wbite, Tinted -

Marie Van Houtte. (T). . . . .56

Madison. (T.). . . . . . . . 53
Pink- - Page

Maman Cochet. (T.) . 53

Mme. Camille. (T.). . 52

Radiance. (H.T.) . . . 60 Red-

Mrs. B. R. Cant. (T.). . 57

Magnafrano. (H.T.) . . I I 3

Rhea Reid. (H.T.). . . 60 


\section{Climbing Roses That Will Cover Quickly,} Trellises, Porches, Buildings, Etc.

Every home has room for a few climbers, because vines around a house decorate it as nothing else does, and to have vines that will hand you forth roses-imagine the pleasure of that!

Where you live makes a difference; roses that will grow to cover your house with bloom in northern New England are not the kinds to do the same in the sunny South. So, think of these things when you order, or, better still, leave it all to your grower, who will select to suit your home and climate. For example, here are three sets, each one good for the section indicated. Order accordingly, and you will get pleasing results.

(See list of climbing roses recommended for this purpose on page 68.)

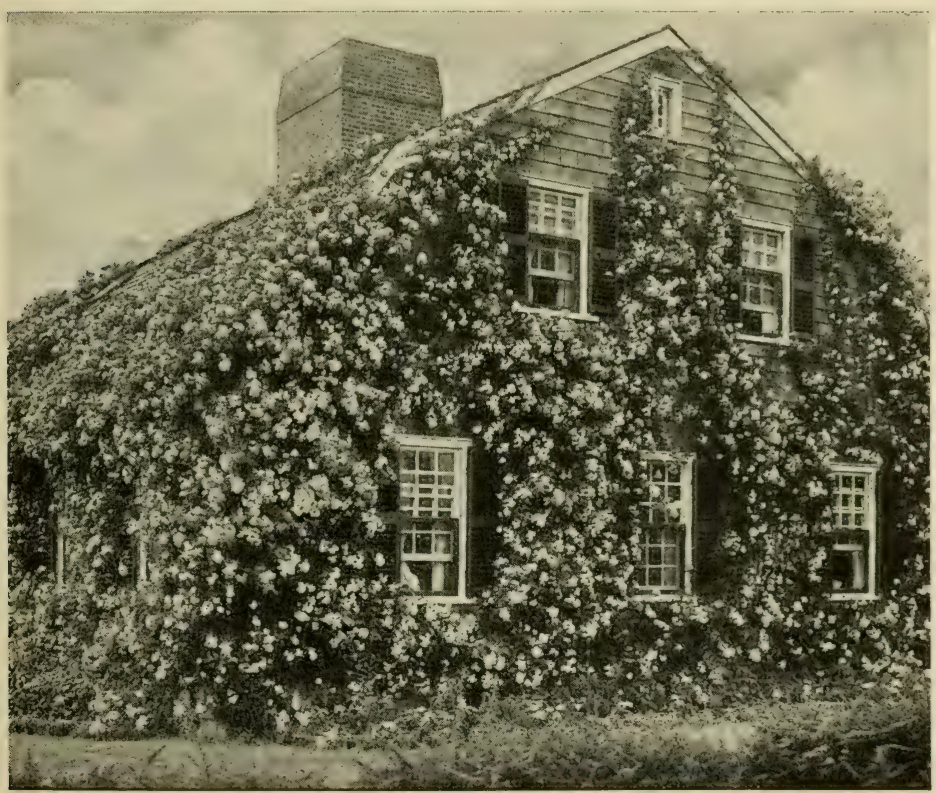

Dorothy Perkins roses in cold New England, growing over a cottage of Thos. W. Lawson, Dreamwold, Massachusetts. 
We recommend the following roses for the uses described on the preceding page:

For a Warm Climate-"Everblooming Climbers"-

Page

Reine Marie Henriette. Red . . . . . . . . . . . . . II5

Mrs. Robert Peary. White . . . . . . . . . . . II5

Marechal Niel. Yellow. . . . . . . . . . . 56

Climbing Pink Maman Cochet. Pink...... . . . . . . . 53

For a Temperate Climate (latitude of Pbiladelphia and New York)-

Dorothy Perkins. Pink . . . . . . . . . . . . 47

Excelsa (Red Dorothy). Red . . . . . . . . . . . . . . 48

White Dorothy Perkins. White . . . . . . . . . . 47

Gardenia. Yellow . . . . . . . . . . . . 48

For a Cold Climate (where winters are long and severe)-

Dr. W. Van Fleet. Pink . . . . . . . . . . . . 47

Mary Lovett. White. . . . . . . . . . . . . . 56

Ruby Queen. Red.. . . . . . . . . . . II5

Tausendschön. Pink and white . . . . . . . . 6r

Archways, Arbors, Summer-Houses, Pergolas, and for Beautifying Boundaries, Fences, Etc.

Certain roses

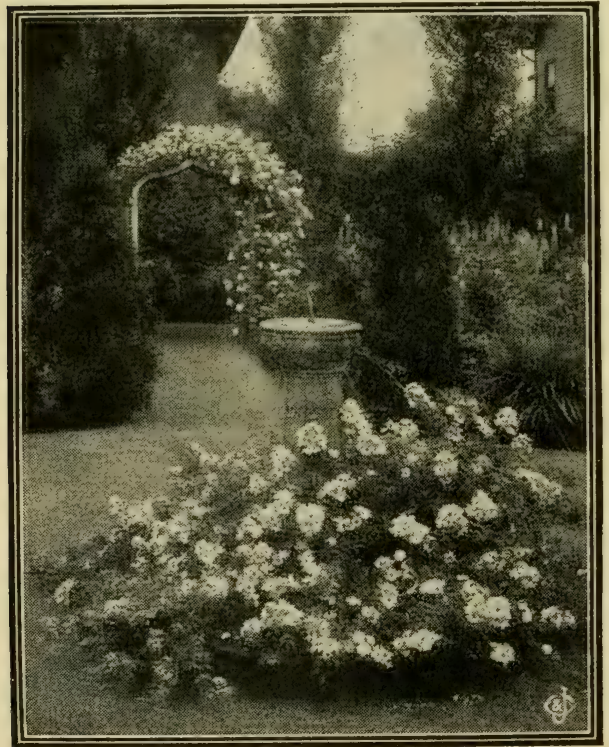

Effective uses of the Wichuraiana lend themselves admirably to being trained over objects on which they can have support. The best kinds for such a purpose, we think, are:

Dorothy Perkins. Page Pink. . . . . 47 Ruby Queen. Red II5 American Pillar, Single. Pink $\because 44$ Excelsa (Red Dorothy Perkins). 48 Tausendschön. Blush ....6r Gardenia. Ýllow . 48

Quite as pretty an effect may be had with certain other kinds by 


\section{ROSES FOR VARIOUS PURPOSES}

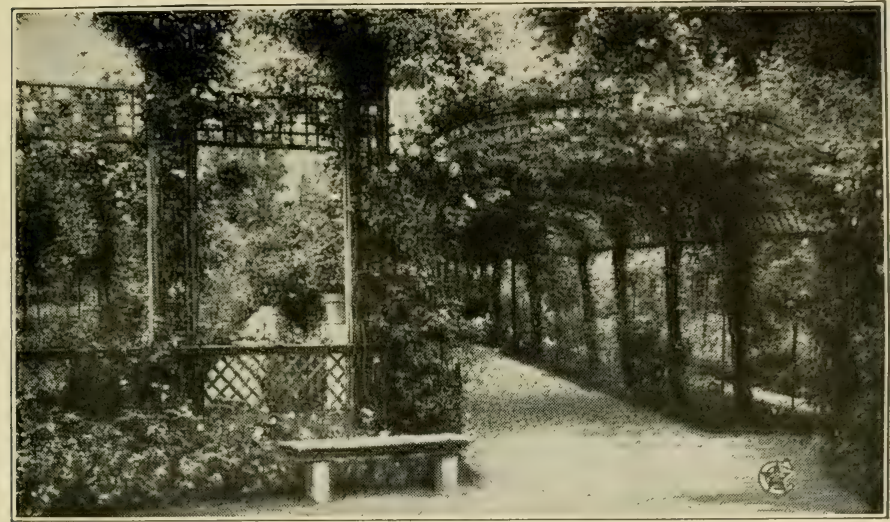

A lovely spot in the famous Graveraux Rose-garden near Paris

allowing them to grow over a fence, as shown on page $7 \mathrm{I}$. Their willowy vine-like branches are very graceful, the foliage is shiny and almost evergreen, giving these the advantage over the Ramblers of being attractive even when not in bloom and almost the entire year.

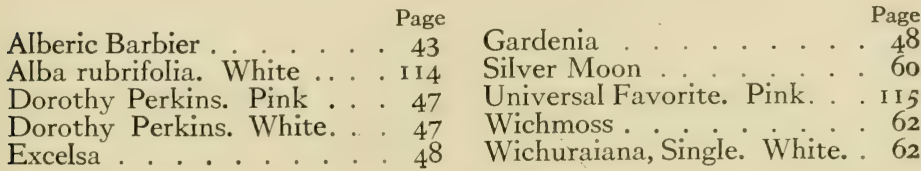

The above-mentioned roses flower during one period of the year only, but are hardier for cold climates than the following, which, if well cared for and properly nourished, will continue to produce some bloom during summer and autumn:

Climbing Gruss an Teplitz. Red . . . . . . . . . . . . . . . 49

Climbing Pink Maman Cochet . . . . . . . . . . . . . . . . 53

Climbing White Killarney . . . . . . . . . . . . . II5

Shower of Gold. Yellow; shiny foliage . . . . . . . . . II5

Climbing Clothilde Soupert. Blush .. . . . . . . . . . IIs

Climbing Killarney. Pink . . . . . . . . . . . . . . . . . . . IIs

Reine Marie Henriette. . . . . . . . . . . . IIs

Mme. Caroline Testout Climbing . . . . . . . . . . . II5 


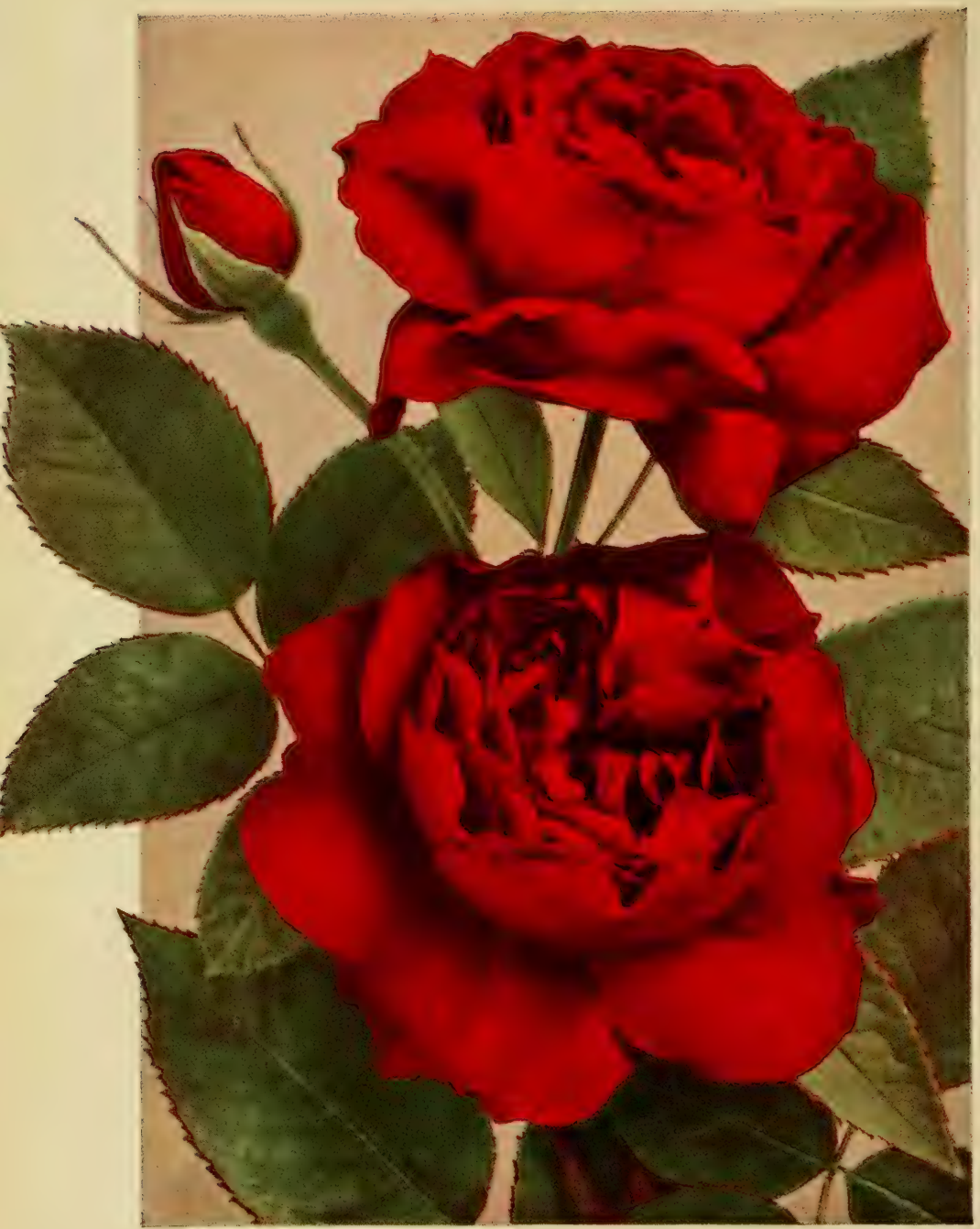

THE STANDARD HYBRID PERPETUAL, GEN. JACQUEMINOT

Do you know the quaint custom that still holds in one of the country towns of Pennsylvania, whereby, in accordance with the will of Baron Stiegel, there is paid for the church property, with an appropriate anniversary celebration, an annual rental of one red Rose?

No other Rose can be counted upon for this service so surely as the dear old favorite "Jack." 


\section{For Beautifying Banks, Stumps, or Other Unsightly Objects}

The Wichuraianas are ideal cover-roses. They are remarkably free from both insects and disease, with foliage clean, bright, and shiny the entire year.

The single-flowered sorts bear bright berries, which the birds like. Enterprising railroad companies use these to hold embankments in place; they also add to the roadside beauty. One plant will easily cover 6 square feet of ground.

Alberic Barbier Shiny foliage; creamy white. Page Alberic Barbier. Shiny foliage; creamy white. . . . . . . . . . . 43 Gardenia (Hardy Marechal Niel). Yellow . . . . . . . . . . . . . 48 Universal Favorite (Double Pink Memorial) . . . . . . . . . I I 5 Wichuraiana. Single. White. . . . . . . . 62

Most of the Wichuraianas are also well suited for covering purposes.

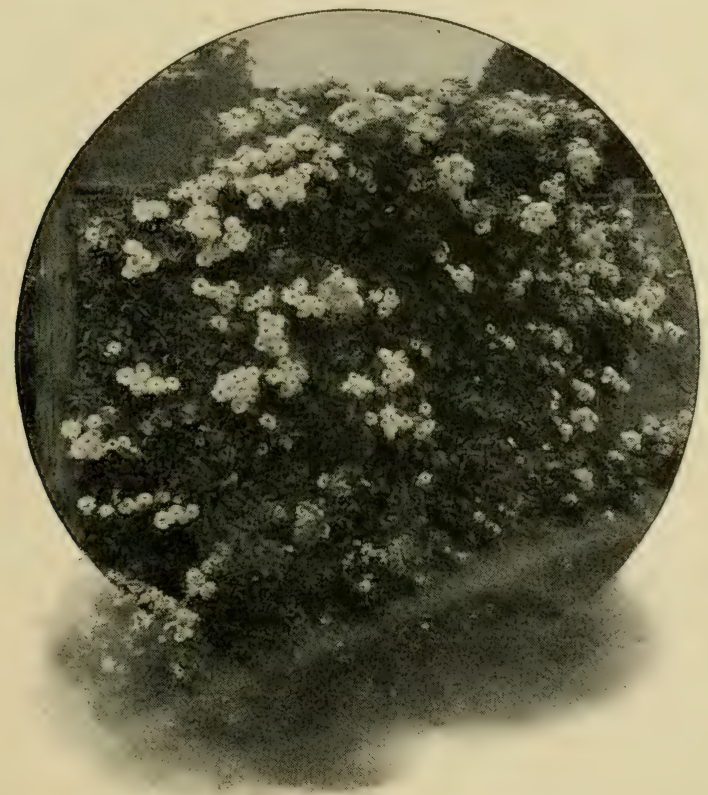

Here is a beautiful hint, easily and cheaply adopted by anyone whose fences are bare. See varieties mentioned above 


\section{For Screen Planting and Borders, or Beautifying the Unsightly}

Almost every lawn might be improved, if some uncomely object or portion in the rear were screened from view. The right kind of roses will do it, and give you something beautiful instead. There are two ways to do it: (I) put up a trellis and train over it the roses named in the above section; or (2) if it be a low screen, you need only to plant the tall, erect-growing Rugosa roses. And if you want a luxuriant growth, dig the ground deeply and give these roses plenty of rich nourishment.

Page Page

Birdie Blye. Pink. . . . 44 Hugonis . . . . . . . 109

Conrad F. Meyer. Silvery pink 46 May Queen. . . . . . . 56

Christine Wright. Pink . . . 46 Ruby Queen. Ruby-red . . . II5

Harison's Yellow . . . . 4 49 Sir Thomas Lipton. White.. . 6I

These eight varieties, if set in one group, should be placed at least 2 to 3 feet apart.

Wonderfully pleasing effects may be obtained for screening out undesirable objects or views by the erection of trellis formations. These may be made of various designs and materials; but, for roses, wood seems to be preferred. Over these train the roses recommended on pages 68 and 69 .

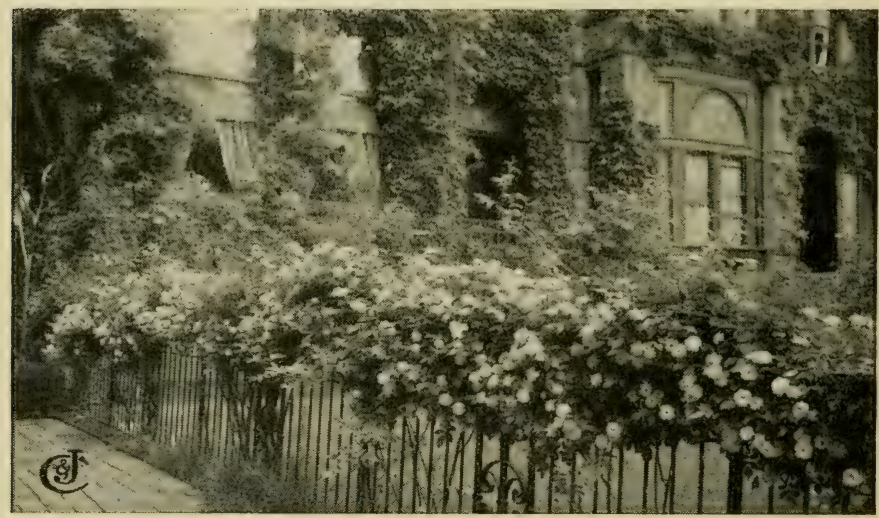

A fence made beautiful with Wichuraiana roses 


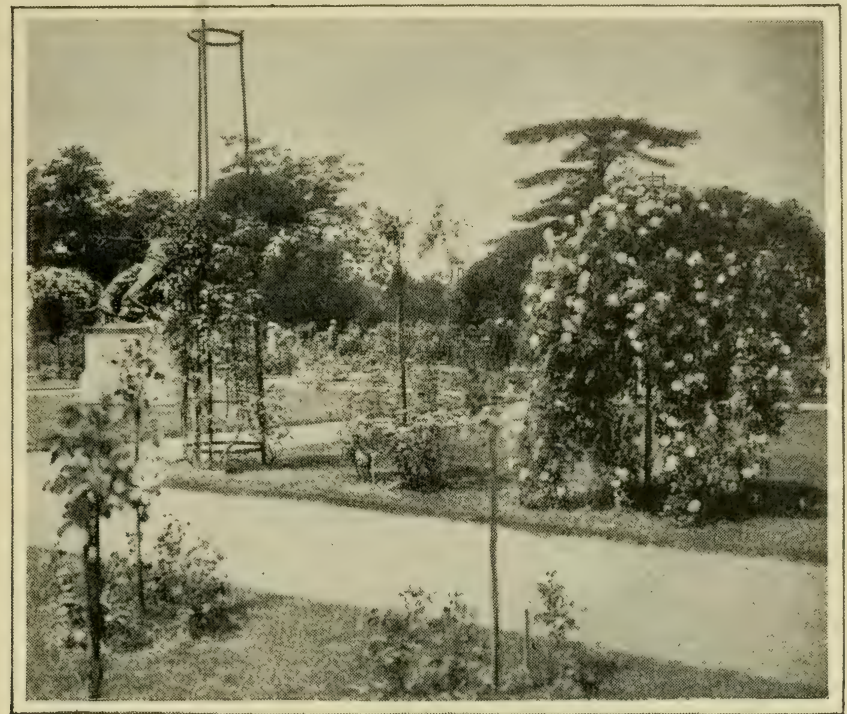

The Tree roses in the Bagatelle Gardens in Paris are much Iarger than are customarily seen in American gardens. Some of these are 12 feet high, having been budded with Wichuraianas that weep to the ground.

\section{Standard or Tree Roses}

Tree roses occupy very little ground space and are quite imposing when planted among shrubbery or perennials. If you arrange them along the sides of a walk they produce an avenue effect (see page 13). A fine effect is produced by planting them among or back of a collection of bush roses, thus making a two-storied rose-bed, as it were.

It pays to have these come to you while dormant.

Frau Karl Druschki. (H.P.) Snow-white.

Etoile de France. (H.T.) Good red.

Paul Neyron. (H.P.) Immense; rich pink.

Ulrich Brunner. (H.P.) Crimsonscarlet.

Jonkheer J. L. Mock. (H.T.) Imperial pink.
Gruss an Teplitz. (H.T.) Often called the "reddest of red roses;" fragrant and freeblooming.

Mme. Caroline Testout. (H.T.) Clear cherry-red.

Mrs. Aaron Ward. (H.T.) Rich yellow.

Pharisäer. (H.T.) Rosy white. 


\section{Rose Hedges}

These boundary markers are certainly coming to be more and more popular as people learn about the splendid qualities of the Rugosa roses, Sweetbriars, or Altaica for this purpose. They are not neat, compact, and uniform in growth as is a hedge of California Privet, but the thick, bushy mass of glossy, crinkled foliage, especially of the Rugosa, gives a particularly fine appearance. They are perfectly hardy in the coldest winters and are more valuable because the foliage is not troubled with either insects or disease.

In warmer countries, or even in our own latitude, a single row of a free-flowering, erect, bushy rose is sure to be pretty and very satisfactory where one wishes simply to mark a boundary, as, for example, between the vegetable- and flowergarden. For this purpose, Gruss an Aachen, (see page 49) is excellent. The small-flowered Polyanthas are also popular, especially Baby Rambler, Marie Pavie, and Baby Dorothy. The list could readily be extended, and each one would be well worth planting. (See list of Polyanthas.)

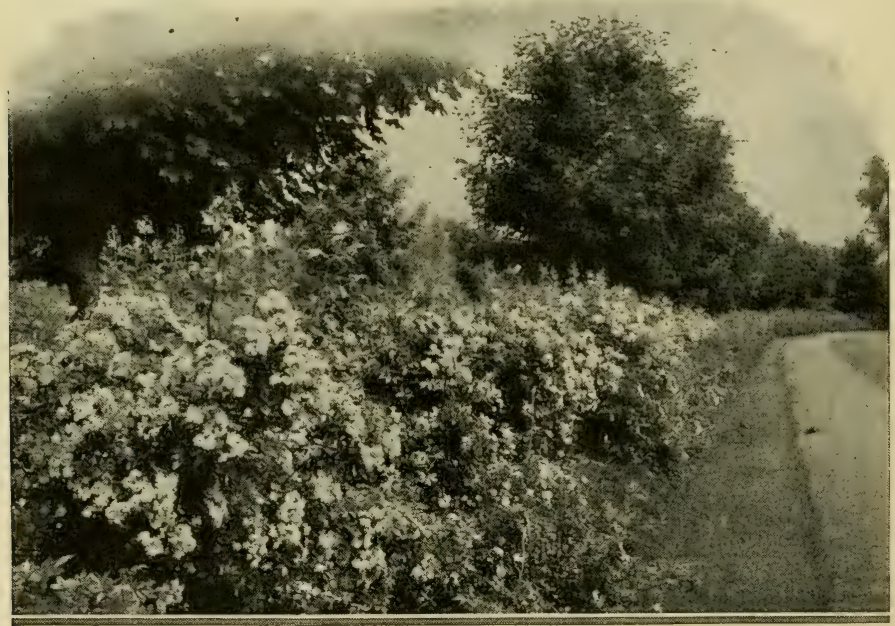

Hybrid Wichuraianas, if given some support, make an excellent hedge 


\section{Roses for the Cemetery}

For some cemeteries we recommend roses that almost care for themselves - the Wichuraiana type. They creep like ivy and make a mat of shiny foliage which is green for eleven months.

Next to these, we like the dwarf, compact-growing, freeflowering Polyanthas, especially the White Baby Rambler, Gruss an Aachen, Marie Pavie, and Echo. If you can care for bush roses, select from the "Best Yet" sets, according to locality. If you want some of the sturdiest growers obtainable, choose from this list:

Sir Thomas Lipton. (H Rug.) White . Page Frau Karl Druschki. (H.P.) White . . . . . . . 48 Mme. Plantier. White . . . . . . . . . . . 75

\section{Single Roses}

These are an interesting group in themselves and represented in various classes. The single Irish roses are best among the Hybrid Teas.

Irish Elegance (see cut) Irish Brightness Irish Fireflame

The species are most interesting specimens, among which is Xanthina. One of the largest flowered of the subspecies is Altaica (see page I09).

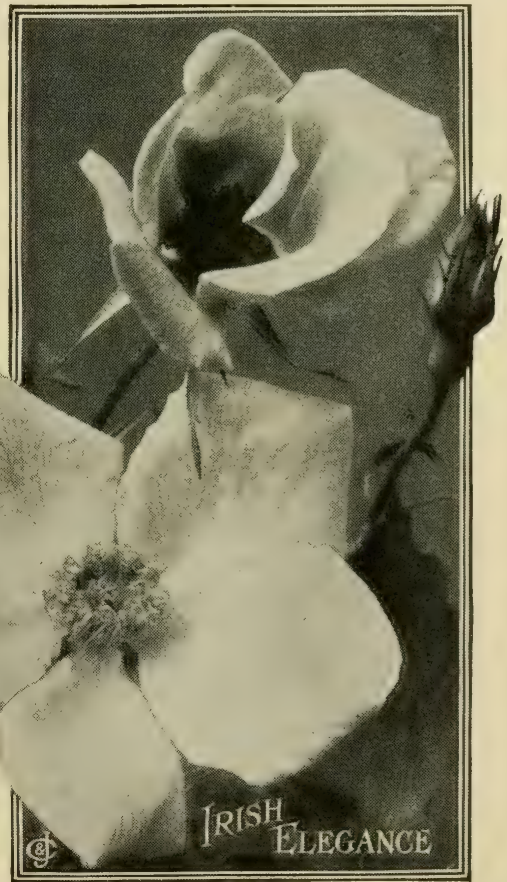

\section{For Edging Beds}

Polyanthas now offer an assortment in nearly every color-class (pages I I3-I I 4 ). 


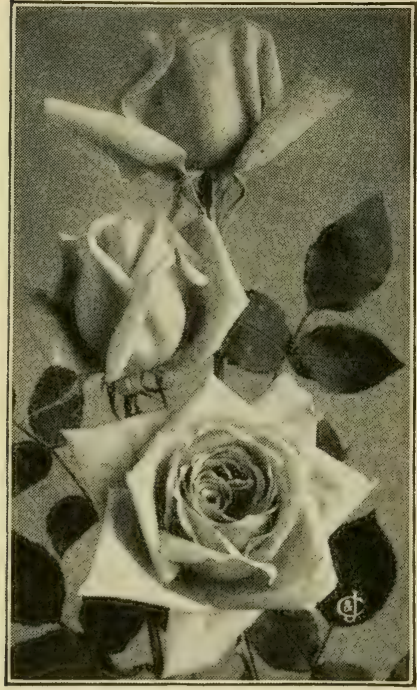

Mme. Abel Chatenay

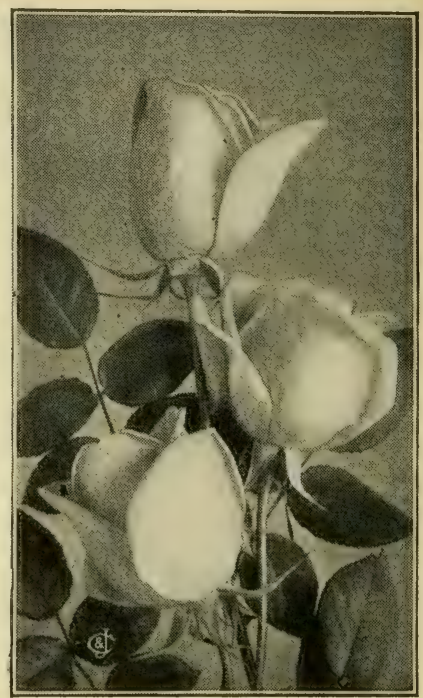

My Maryland

\section{For "Forcing" under Glass or for Indoor Winter Bloom}

These varieties are grown by professional florists in glasshouses where they can with nicety regulate the supply of heat and moisture, to produce the long-stemmed "beauties" seen in florists' windows. While a greenhouse or conservatory is a wonderful help, indeed essential for best results, some people have these same roses during the winter, blooming beautifully in their homes by growing them where they have plenty of sunlight and air. A thing to remember is that coal gas is very injurious to plant life, therefore must be carefully guarded against. They are: American Beauty, Hadley, Irish Fireflame, Jonkheer J. L. Mock, Killarney, Killarney Brilliant, Kaiserin Augusta Victoria, Lady Alice Stanley, Lady Hillingdon, Madison, Mme. Abel Chatenay, Mrs. Aaron Ward, Mrs. B. R. Cant, Mrs. Charles Russell, Mrs. George Shawyer, My Maryland, Ophelia, Radiance, Rhea Reid, Richmond, Sunburst, Wellesley, White Killarney. 


\section{Selections for Special Sections of the United States of America}

Those of our readers who live in the more thickly settled sections of our country will recognize, in the following, our dependence upon the modern scientific method of learning the "best roses" for certain localities, i.e. the method of actually testing them. We have had the good fortune to visit personally and to know the rose experts in many sections, and they severally have been so kind as to give us the benefit of their valuable experience, each in the form of a list of roses they have found to thrive. We stand back of these recommendations. Other lists which we offer of roses best adapted for various purposes are bound to prove helpful as well as suggestive. (See pages 64 to 76. .)

\section{For the Pacific Northwest}

Mr. J. A. Currey, of Portland, Oregon, sent us the following list as the result of a vote of representative amateur and professional growers in his part of the country, showing the best roses for various purposes:

\section{Twelve best roses for general cultivation}

Frau KarI Druschki

Edward Mawley

General MacArthur

Gruss an Teplitz

Hugh Dickson

Mme. Caroline Testout
Mme. Melanie Soupert

Maman Cochet

Miss Kate Moulton

Mrs. John Laing

Richmond

UIrich Brunner

\section{Six best climbing or rambling roses}

American Pillar Dorothy Perkins.

Mme. Alfred Carriere
Mme. Caroline Testout, Climbing Tausendschön

Wm. Allen Richardson

Six best red roses for general cultivation

Avoca

GeneraI MacArthur

Hugh Dickson
J. B. Clark

Richmond

Ulrich Brunner 


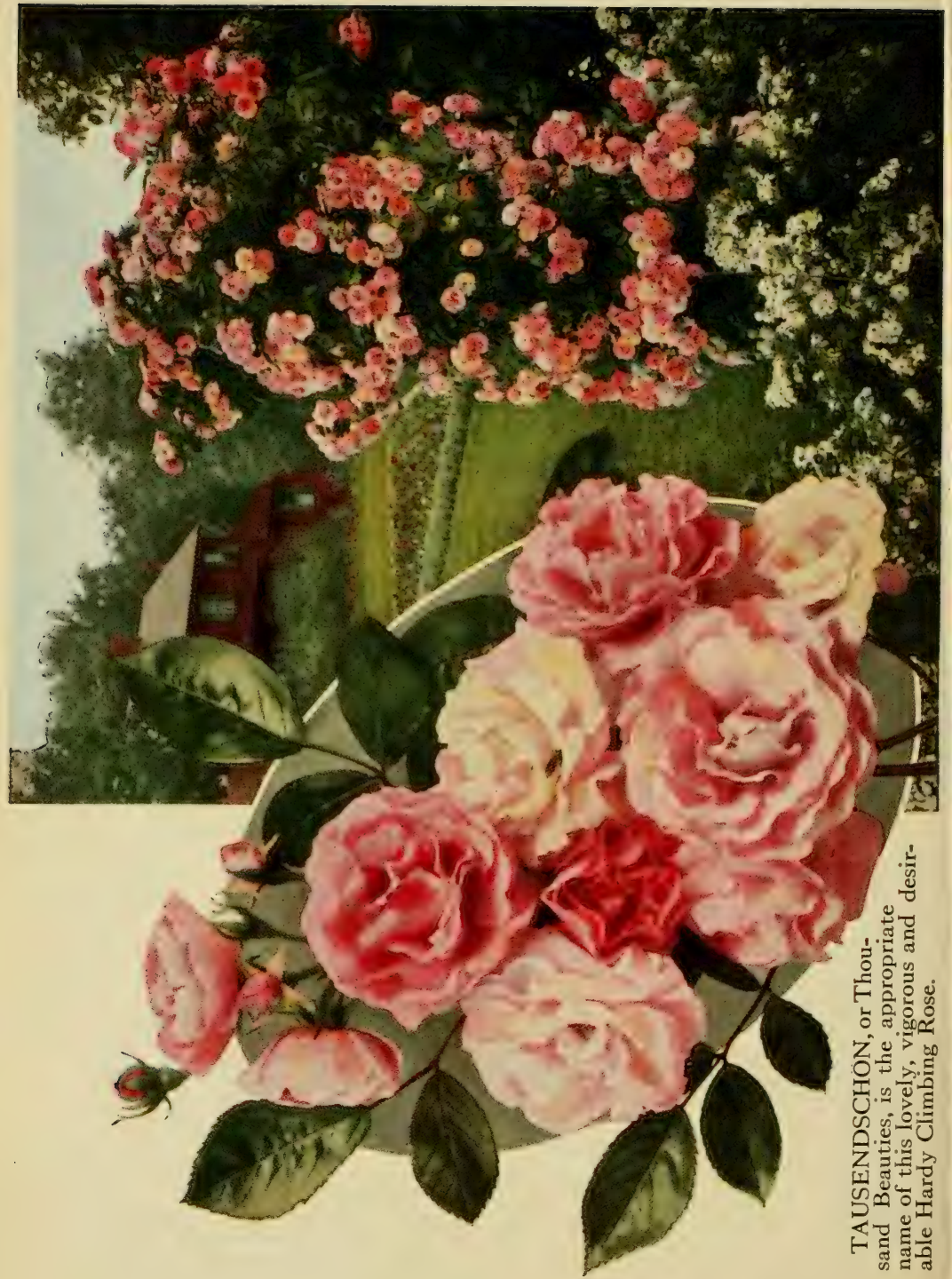


Roses for the Pacific Northwest, continued

Six best white roses for general cultivation

British Queen

Florence Pemberton

Frau Karl Druschki
Kaiserin Augusta Victoria

Maman Cochet

Mrs. Foley Hobbs

Six best pink roses for general cultivation

Belle Siebrecht

Lady Ashtown

Mme. Caroline Testout
Maman Cochet

Miss Kate Moulton

Mrs. John Laing

Six best yellow roses for general cultivation

Joseph Hill

Lady Hillingdon

Mme. Melanie Soupert
Mme. Ravary

Mrs. Aaron Ward

Sunburst

\section{For Minneapolis and Vicinity}

Mr. Theodore Wirth, now superintendent of the parks of Minneapolis, and formerly builder of the famous rose-garden of Elizabeth Park, Hartford, Connecticut, recommends for his section of the country the following list of roses:

\section{Hybrid Perpetuals}

Anna de Diesbach

Heinrich Schultheis

Mrs. John Laing

Paul Neyron

Captain Hayward

Hugh Dickson
Frau KarI Druschki

Mme. Gabriel Luizet

UIrich Brunner

Clio

Marshall P. Wilder

General Jacqueminot

\section{Hybrid Teas}

Gruss an Teplitz

Killarney, Pink and White

La France

Caroline Testout

Mary, Countess of IIchester
Kaiserin Augusta Victoria

Mme. Jules Grolez

General MacArthur

Souvenir du President Carnot

Maman Cochet, White and Pink

\section{Climber Ramblers}

Crimson Rambler

GoIdfinch

Wm. C. Egan
Tausendschön. See illustration in color on opposite page.

Rosa setigera 


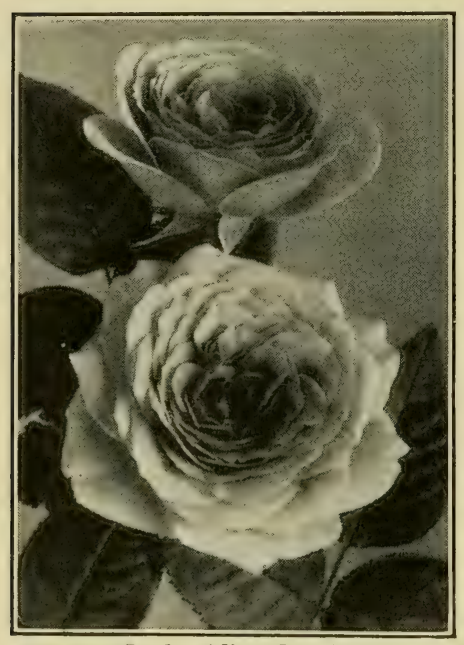

Lady Alice Stanley

Roses for Minneapolis and Vicinity, continued

\section{Polyanthas}

Mme. N. Levavasseur (Baby Rambler)

Marie Pavie

MIle. Cecile Brunner

Clothilde Soupert

Orleans

Mme. Zelia Bourgeois

Jessie

Gloire de Polyantha

Primula

\section{Climbing Wichuraianas}

Dorothy Perkins

Hiawatha

La Fiamma

The Farquhar Rose

Paradise

Minnehaha

\section{For Central New York State}

Rev. E. M. Mills, D.D., President of the Syracuse (New York) Rose Society, recommends the following as the best collection of twenty-frve Hybrid Teas and Teas for Syracuse and vicinity, considering hardiness, variety of color, vigor of growth, and freedom of bloom:

\section{Hybrid Teas}

Antoine Rivoire

British Queen

Chateau de Clos Vougeot

Duchess of Wellington

Florence Pemberton

General MacArthur

Gruss an Teplitz

Killarney, Pink

Killarney, White

Königin Carola

Harry Kirk

Lady Hillingdon

Marie Van Houtte
Lady Alice Stanley

Lady Ashtown

Laurent Carle

Lyon Rose

Mme. Melanie Soupert

Mme. Segond Weber

Miss Cynthia Forde

Mrs. Aaron Ward

Ophelia

Sunburst

\section{Teas}

Mrs. B. R. Cant

Wm. R. Smith 


\section{For Roslyn and Northwest Long Island}

Admiral Aaron Ward recommends the selection given below. It was based upon the following requirements: autumn blooms indispensable; weak growers barred; also plants of huge growth, like La Tosca or Gruss an Teplitz, except for use in mass effects; flowers to be full, no thinner than Pharisäer; climbers not included.

\section{Pernetiana}

Constance

Lyon Rose

Mme. Antoine Mari

Mme. Jean Dupuy.

Marie Van Houtte

Hybrid Perpetual

Frau KarI Druschki
Mme. Edouard Herriot

Willowmere

Tea

Paula

Wm. R. Smith

\section{Hybrid Tea}

Augustine Guinoisseau

Amateur Teyssier

Chateau de Clos Vougeot

Dean Hole

Duchess of Wellington

EarI of Warwick

General-Superior Arnold Janssen

General MacArthur

Geo. C. Waud

Gruss an Teplitz

Gustav Grunerwald

Königin Carola

Lady Alice Stanley

Lady Ashtown

Lady Greenall

Laurent Carle

Lieut. Chauré

Mabel Drew

Mme. Abel Chatenay

Mme. Jules Bouche

Mme. Jules Grolez
Bourbon

Souv. de Ia Malmaison

Note.-Frau KarI Druschki, Gruss an Teplitz, and Mrs. A. R. Waddell are too vigorous to be grown with the rest. Mrs. A. R. Waddell, Mme. Edouard Herriot and Mme. Melanie Soupert, are semidouble. 


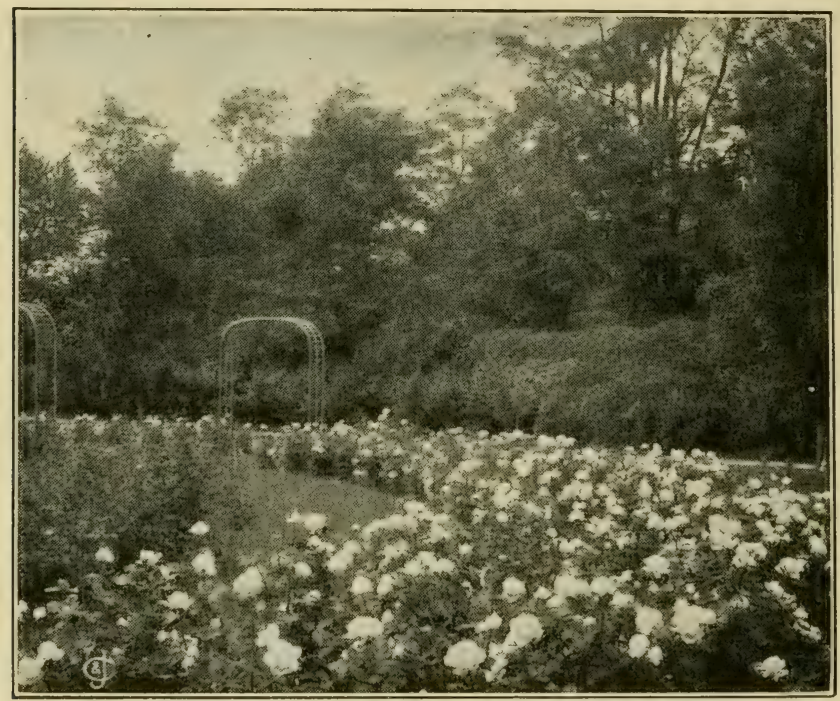

Rose beds of one variety make a fine effect

\section{For Philadelphia and Vicinity}

Dr. Robert Huey, the eminent amateur whose success has been an inspiration to many others, and who is broadly recognized as an authority on garden roses, recommends the following varieties:

\section{Hybrid Teas}

Antoine Rivoire

Betty

Caroline Testout

Mrs. MacKellar

Duchess of Wellington

EIlen Wilmott

George C. Waud Jonkheer J. L. Mock Joseph Hill

Killarney

Lady Alice Stanley

Lady Ashtown

Laurent Carle

Lyon
Mabel Drew

Mme. Edouard Herriot

Mme. Hector Leuillot

Mme. Jules Bouche

Mme. Leon Pain

Mrs. Aaron Ward

Mrs. A. R. WaddeII

Mrs. Harold Brocklebank

Pharisäer

Prince de BuIgarie

Robert Huey

Viscountess Folkestone

Willowmere 
Roses for Philadelphia and Vicinity, continued

Frau KarI Druschki

UIrich Brunner

Captain Hayward

Oscar Cordel

Maman Cochet

White Maman Cochet Harry Kirk
Hybrid Perpetuals

Baroness Rothschild

Mrs. John Laing

Mrs. George Dickson

Susanne Marie Rodocanachi

Tea Roses (Hardy)

Hugo Roller

Safrano

\section{Climbing and Pillar Roses}

Reine Marie Henriette

Excelsa

Dr. W. Van Fleet

Dorothy Perkins

Hiawatha

Gardenia

Elisa Robichon

\section{For Washington, D. C., and Points South}

Dr. W. Van Fleet was the hybridizer of many excellent roses, including especially the hardy climbers like American Pillar, Dr. W. Van Fleet, Mary Lovett, and many others. He is now associated with the Department of Agriculture at Washington, D. C., and gives us his opinion in the following lists:

Pink

Killarney, H.T.

Mme. Abel Chatenay, H.T.

Mme. Gabriel Luizet, H.P.

Maman Cochet, $\mathrm{T}$.

Mrs. John Laing, H.P.

CardinaI, H.T.

Etoile de France, H.T.

General MacArthur, H.T.

Gruss an Teplitz, H.T.

Frau Karl Druschki, H.P.

Gloire Lyonnaise, H.P.

Kaiserin Augusta Victoria, H.T.
Red

My Maryland, H.T.

Paul Neyron, H.P.

Radiance, H.T.

Wm. R. Smith, T.

J. B. Clark, H.P.

Richmond, H.T.

Ulrich Brunner, H.P.

\section{White}

Killarney, White, H.T.

White Maman Cochet, T.

\section{Yellow}

Etoile de Lyon, T.

Lady Hillingdon, $T$.

Sunburst, H. T. 


\section{For the South Atlantic and Gulf States}

Some people are said to have been born with silver spoons in their mouths, and correspondingly the young man who recommends the following list, as proven among the choice "doers" for North Carolina and the South, might be said to have been "born with a rose in his buttonhole." He was able as a schoolboy, to identify almost any rose by its foliage alone. After several years in the South, with his excellent powers of observation, we feel that he is weIl qualified to judge of the roses that can be definitely depended upon for localities corresponding to the west-central part of North Carolina.

\section{Climbers}

Gruss an Teplitz, Climbing

Kaiserin Augusta Victoria, Climbing

Killarney, Climbing

Mme. Eugene Marlitt

Alexander Hill Gray

Duchesse de Brabant

General MacArthur

Gruss an Aachen

Jonkheer J. L. Mock

La Tosca

Mme. Melanie Soupert

Note.-Practically all the vigorous-growing Bengals, Noisettes, Teas, and Hybrid Teas are good for the South.-Editor.

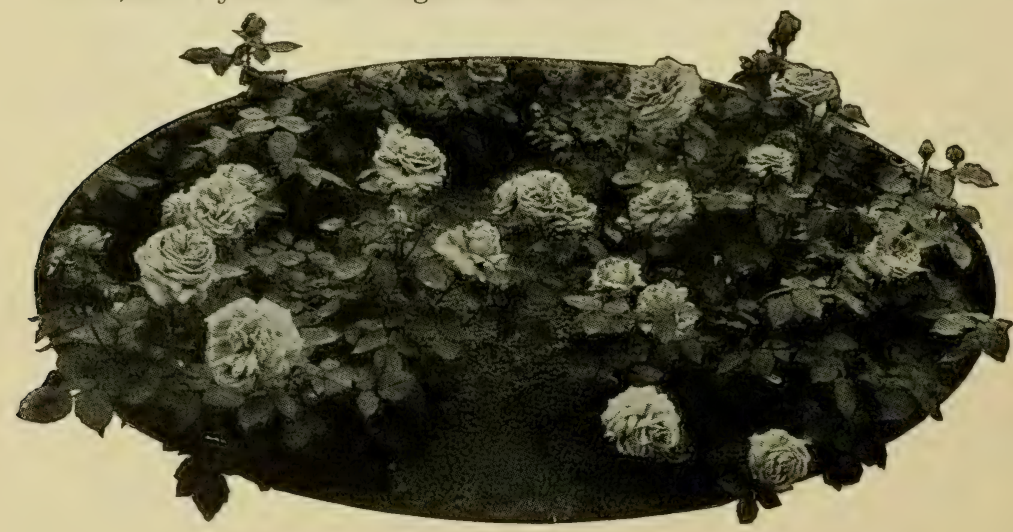

Maman Cochet

Maman Cochet, White

Mrs. B. R. Cant

Radiance

Wellesley

Wm. R. Smith
Maman Cochet, Climbing

Reine Marie Henriette

Souv. of Wootton, Climbing
Bush 


\section{For Chicago and the North}

By W. C. EGAN

Editor's Note.-People who live in the cold Northwest may think it useless to attempt growing roses, but, as Dr. Bailey says, "the success of the rose in this country is very Iargely a question of the selection of adaptable varieties." The Lake Fcrest section, on the west shore of Lake Michigan and north of Chicago, is typical of a large area to the north and west. In this section there is no one better able to speak from broad experience than W. C. Egan, the eminent horticulturist of Highland Park. In response to our request for a list of roses best suited to his cold country, he very generously sent us a contribution which, without further comment, we are most happy to present to our readers.

While the section bordering Lake Michigan from Chicago northward, called the North Shore district, is not a rosarian's paradise, we can have roses from early June until frost. This we can accomplish with but little care, except in the case of the Hybrid Teas, which require proper attention. Given this, they flood us with a shower of bloom that makes them worthy of cultivation, even if we treat them as annuals, and plant fresh stock each year. "Expensive!" you say. WeIl, yes, to a certain extent; but so are bedding-plants, and babies, and automobiles; but the results in all cases are worth the money. Some spend money lavishly for winter decorations that fade in the night. The same amount, spent for Hybrid Teas planted out early in the spring, gives one pleasure all summer. They are easily cared for, if the instructions given in this work are carried out. For those who possess small grounds and have but little time to attend to them we have that poor man's blessing, the Rosa rugosa, and its hybrids. This Japanese rose does not know how to "catch cold," and will stay longer with you and give far more pleasure than any poor relation. It blooms profusely in June and scatteringly all through summer, ripening its bright red, cherry-like berries during the late summer months. Its foliage is unusually fine and insect-proof. This feature alone should be highly appreciated, for the beauty of foliage is more than half the beauty of any plant. This rose was known to rosarians as early as 1845 , but its beauty and hardiness 
and its value in hybridizing were not appreciated until some forty years afterward, when Mr. Robert C. S. Carmen, of New Jersey, and M. Georges Bruant of Poitiers, France, gave us the hybrids, Agnes Emily Carmen, and Mme. Georges Bruant. While the former was produced frrst, thus giving the honor of producing the first Rugosa hybrid to an American, it was delayed in its propagation, and the French rose was the first on the market. In all of Mr. Carmen's experiments the Rugosa rose was the mother plant, and it is a singular fact that the Agnes Emily Carmen rose, bearing flowers having the color and scent of the General Jacqueminot rose, should have Harison's Yellow as the male parent. The success of these hybridizers caused others to enter the freld, and we now have a host of good forms, all hardy and reliable. Where these hybrids possess some Tea blood, unusually cold winters may kill them back somewhat. The handsome Rugosa hybrid, Conrad F. Meyer, is sometimes "cut back" in winter. This type and its hybrids are splendidly adapted for forming entire hedges or large groups, and may be depended upon for flower and foliage.

The well-known dwarf rose, Hermosa, and the writer made their first appearance before the public at about the same time, and the former has graced our gardens for seventy-frve years. I $t$ is reliable and hardy with but little protection, and is one of the best bedders today. The same may be said of the Clothilde Soupert, one of the Iargest-flowered forms of the Polyantha class, introduced in I884. In I880, Veuve Ducher introduced the charming dwarf Polyantha, Mlle. Cecile Brunner, the queen of the so-called Fairy rose class, hardy with slight protection, and admirable for corsage bouquets. Its miniature buds, so delightfully tinted, are admired by all, especially by the gentler sex.

Who has not admired the Cherokee rose of the southern states, an escaped exotic, being the Chinese Rosa sinica, that has taken so kindly to the conditions offered as to thrive there on the waysides and fence corners? We of the North can have its counterpart, all except its evergreen foliage, in the extremely hardy Rosa spinosissima var. Altaica, 


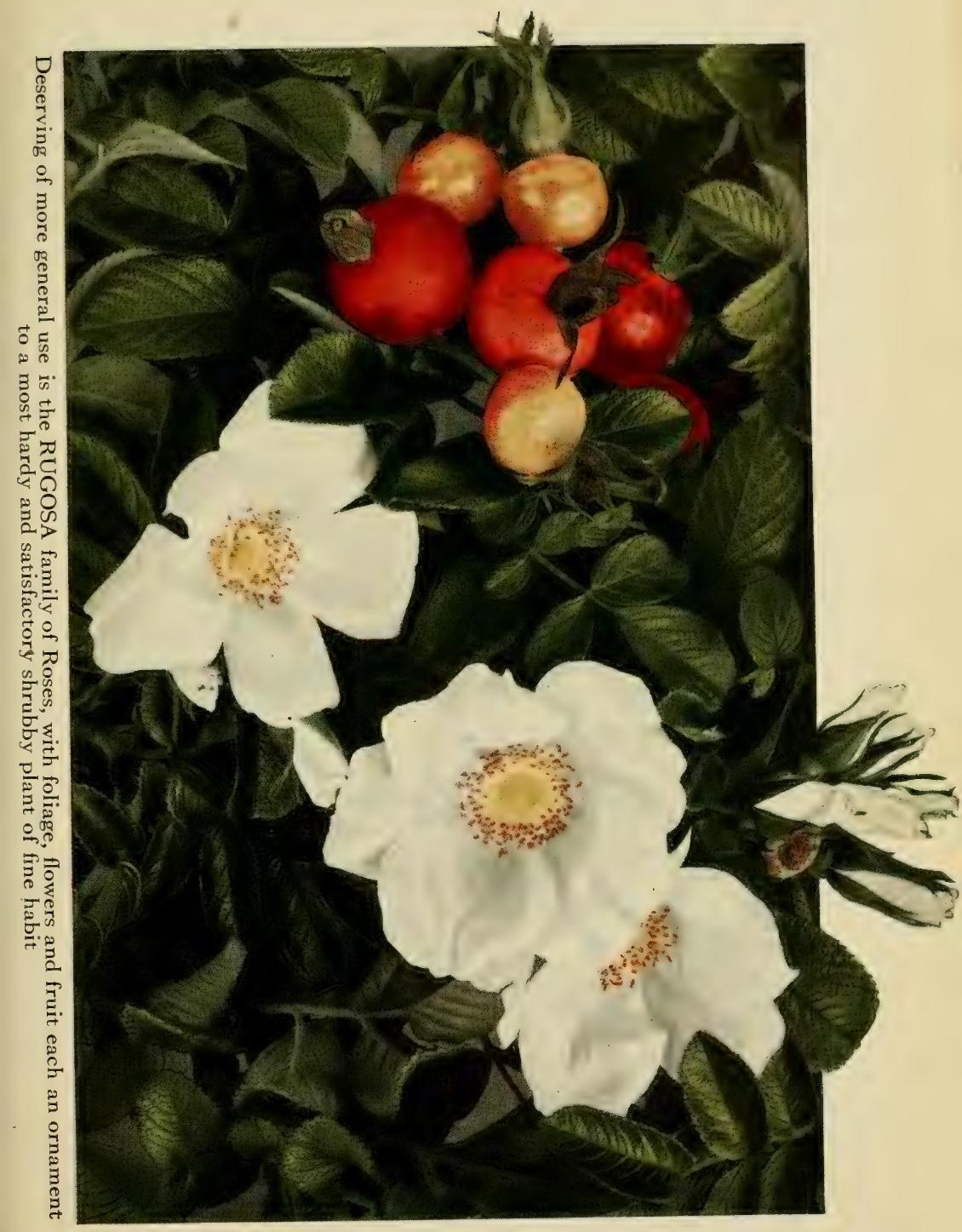


from the Altai Mountains in Siberia. When in bloom, it is a charming sight in the purity of its single, pure white flowers. I cannot understand why this rose is scarce and hard to find, as in good soil it suckers rapidly and thus an increased stock is easily obtained.

The old-fashioned Sweetbriar, with its heaven-born perfume, often winter-kills here, but I grow it in among some tall-growing barberries through whose branches the Briar thrusts its long canes. The barberry shades the Briar canes in winter and but little loss occurs.

I tried Lord Penzance hybrids and, much to my regret, could not carry them over winter, so the charming Lady Penzance was banished from "Egandale."

The Persian Yellow and Harison's Yellow, as well as all the Mosses, are hardy here.

AII of the Baby Ramblers do weIl here, slightly protected, and are well fitted for borders of large rose-beds. Ennchen Müller is splendid; as a cut-flower, each well-grown truss is a bouquet in itself; and, the flowers being loosely arranged, give an airy elegance to the decoration. The color is good in daylight or electric, - a desirable quality in any flower.

Hybrid Perpetuals and those grown as such require winterprotection. Some stand this covered-up condition better than others. Here is a list I gave in Bailey's "Cyclopedia of American Horticulture" some years ago, and I would not change it now. Undoubtedly, there are many more that will do as well if tried, but there are enough listed to create a garden for anyone.

The winter of $1898-1899$ was the most severe in this section I ever experienced, and many trees and shrubs, considered "iron-clad," were killed. The following is a list of roses which wintered here under protection and which came out in good condition:

Captain Christy

Captain Hayward

Garden Favorite

General Jacqueminot

John Hopper

La Rosiere
Louis Van Houtte

Magna Charta

Mrs. Paul

Mrs. R. G. Sharman-Crawford

Paul Neyron

Prince Camille de Rohan 
The following eleven were in fair condition and recovered their form during the season:

Alfred Colomb Anna de Diesbach Baronne Provost Countess of Oxford Eugene Furst Lyonnaise
Mme. Gabriel Luizet

Mme. Victor Verdier

Pierre Notting

Prince of Wales

UIrich Brunner

This section, together with many in the northern states, suffered for the want of a suitable number of climbing roses that might be carried over the winter with an easily prepared protection, until the advent of the Crimson Rambler, which reached England from Japan in $\mathbf{1} 878$. This was followed soon after by Rosa Wichuraiana and its hybrids. Up to this time we had to be content with Queen of the Prairie, Baltimore Belle, Russell's Cottage, and Multiflora rose Greville, or Seven Sisters. The first two were produced by Feast of Baltimore in 1843 by hybridizing that most excellent hardy Prairie rose, $R$. setigera, with some of the garden forms of the day. I have often wondered why hybridizers had not used this hardy semi-climbing rose more frequently in their work. About all the climbing roses, bearing a large percentage of Rugosa or Wichurai- $\quad$ anablood, are hardy with a slight protection in is merely a matter of winter. Which is the best choice.

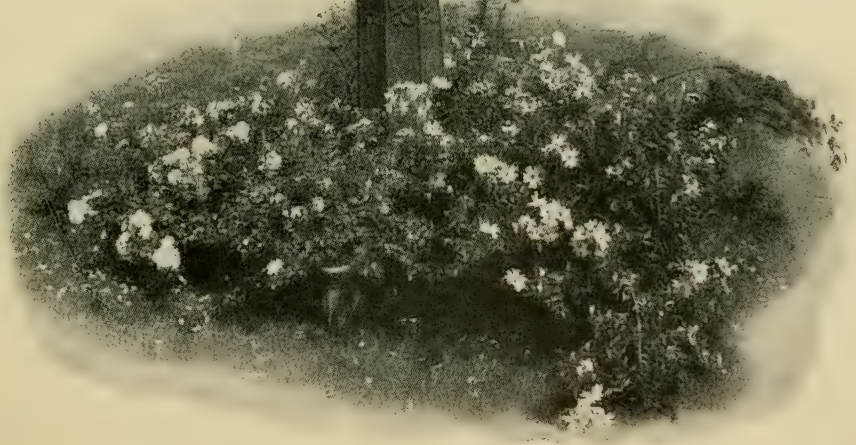




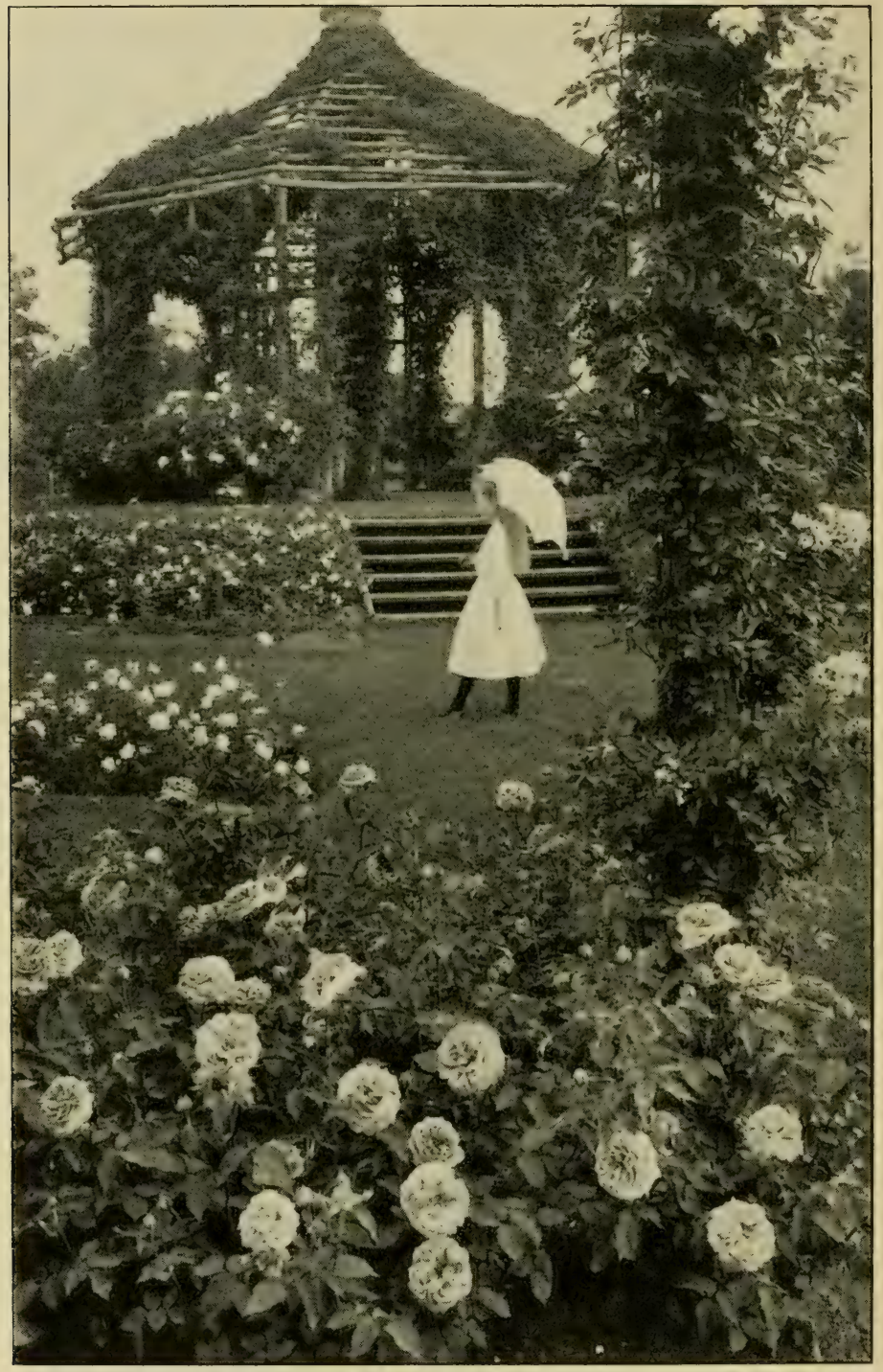

In Elizabeth Park Rose-garden, Hartford, Connecticut 


\section{The Increasing Regard for Roses}

In his book, "The Cultivated Man," Charles W. Eliot says: "A brook, a hedge-row, or a garden is an inexhaustible teacher of wonder, reverence, and love."

Another one of "America's noblemen," G. A. Parker*, with exquisite feeling, thus portrays the possible influence of the rose on the lives of men, when, in telling of the rosegarden at Elizabeth Park, he says:

"I have come to think of beauty as the love-letter of the Creator, through which He is wooing us unto Himself; for beauty is spiritual, and not physical.

"A love-letter is a message into which the sender puts a part of his very self, and the one who receives it, in some mysterious way, weaves it into a part of his very life. It matters little what words are used or how the message is sent, providing it becomes a part of the sender and of the receiver. Surely the Creator uses a most beautiful form when He avails Himself of the roses to convey His message."

Among the real rose-lovers now scattered widely over our great country, it is difficult to conceive of a finer loyalty than already exists toward the flower of their choice. Such devotion as theirs is bearing fruit. Better roses in their gardens are arousing more abundant admiration on the part of neighbors. This results in more "recruits." Rose societies spring up here and there. The members help each other, and more and more each one comes to know the joy of growing one's own roses. This is just what has been going on in many sections of our great country. The delights of rose-growing have been revealed to vastly increasing numbers of amateurs within the past few years. The "garden magazines" have helped. The "garden clubs" have been a prominent factor.

There are, perhaps, half a dozen rose men lecturing $\dagger$ on this fascinating subject and forwarding the good work. All have helped, and the combined efforts of these various agencies are beginning to bloom into activities of great promise.

* "American Rose Annual," 1916, pages 71, 72.

$\dagger$ A list of these will be furnished on request. 


\section{The American Rose Society}

Ten years ago, what we might call the hub of these various movements - the "American Rose Society" - was in no very prosperous state. Amateurs had almost no part in it. Little attention was given to outdoor roses or to rose-gardens. All that is changing. Happily local rose societies to the number of six have already become affiliated with the parent society. The American Rose Society has this year issued, under the able editorship of J. Horace McFarland, a "Rose Annual," worthy to be compared with that of any other national Rose Society. We recommend it to the perusal of our readers. It is not a book of cultural information, but rather treats of the present status of the rose in America, and of the current activities and accomplishments of amateurs and others within and without the American Rose Society (see Bibliography, page 105).

The purpose of the American Rose Society is stated in the Constitution, as follows:

I. To increase the general interest in the cultivation and improve the standard of excellence of the rose for all the people.

2. To foster, stimulate, and increase the production, in every possible way of improved varieties of the rose, suitable to our American climate and requirements.

3. To organize a system of exhibitions at such times and places as this Society may, from time to time, decide on; to offer prizes of money, of gold, silver, and bronze medals, and certificates of merit, for meritorious new varieties of roses; also to offer prizes of money, cups, etc., for excellence of exhibits made at shows held by the Society.

It is also proposed that the Society disseminate to its members the Iatest information pertaining to the rose, recommending new varieties of undoubted merit; describing the best methods of culture, how to fight insect and fungoid pests, the proper use of manures; and giving other information from the pens of leading experts that will be worth many times the cost of membership, especially to amateurs.

The Editor of this book for several years has been associated with the work of The American Rose Society and is warmly interested in its progress. He would feel very much pleased, therefore, if this little work might bring more roselovers into membership with it. Full information regarding fees and privileges will be cheerfully furnished upon application to Editor "How to Grow Roses," West Grove, Pa. 


\section{Rose Test-Gardens}

But perhaps the most important step of all in the last few years for the American rose world is the establishment, in various geographical locations, of rose test-gardens:

At Arlington Gardens, Washington, D. C., known as the National Rose Test-garden; under the care of the Department of Agriculture.

At Ithaca, New York; under the care of the College of Agriculture of Cornell University.

At Hartford, Connecticut; under the care of the authorities of Elizabeth Park.

At Minneapolis, Minnesota; under the care of the authorities of Lyndale Park.

To each of these gardens already have been sent, on an average, nearly four hundred varieties, and from one to two thousand roses, which this year will be ready for test and determination of kinds that may be recommended in each locality. Established thus under the care of permanently organized institutions and under the thoroughgoing care and attention of able specialists, there is promise of collecting most valuable information for amateur rose-growers living in climates corresponding to these spots. The guidance available from such tests is bound, we think, to prove a great boon in saving beginners, especially, from loss entailed by trying out unworthy sorts.

The official scale of points heretofore used by the American Rose Society for judging outdoor roses is as follows:

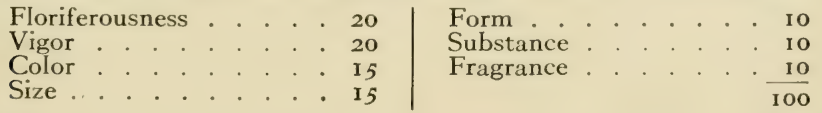

These tests should serve to center attention upon the need in America for more roses adapted to our varied climatic conditions, and thus encourage hybridizers to the work of developing our native species.

Another of the noteworthy steps forward in the past few years is the awakening of city authorities to the possibilities and value of municipal rose-gardens. 


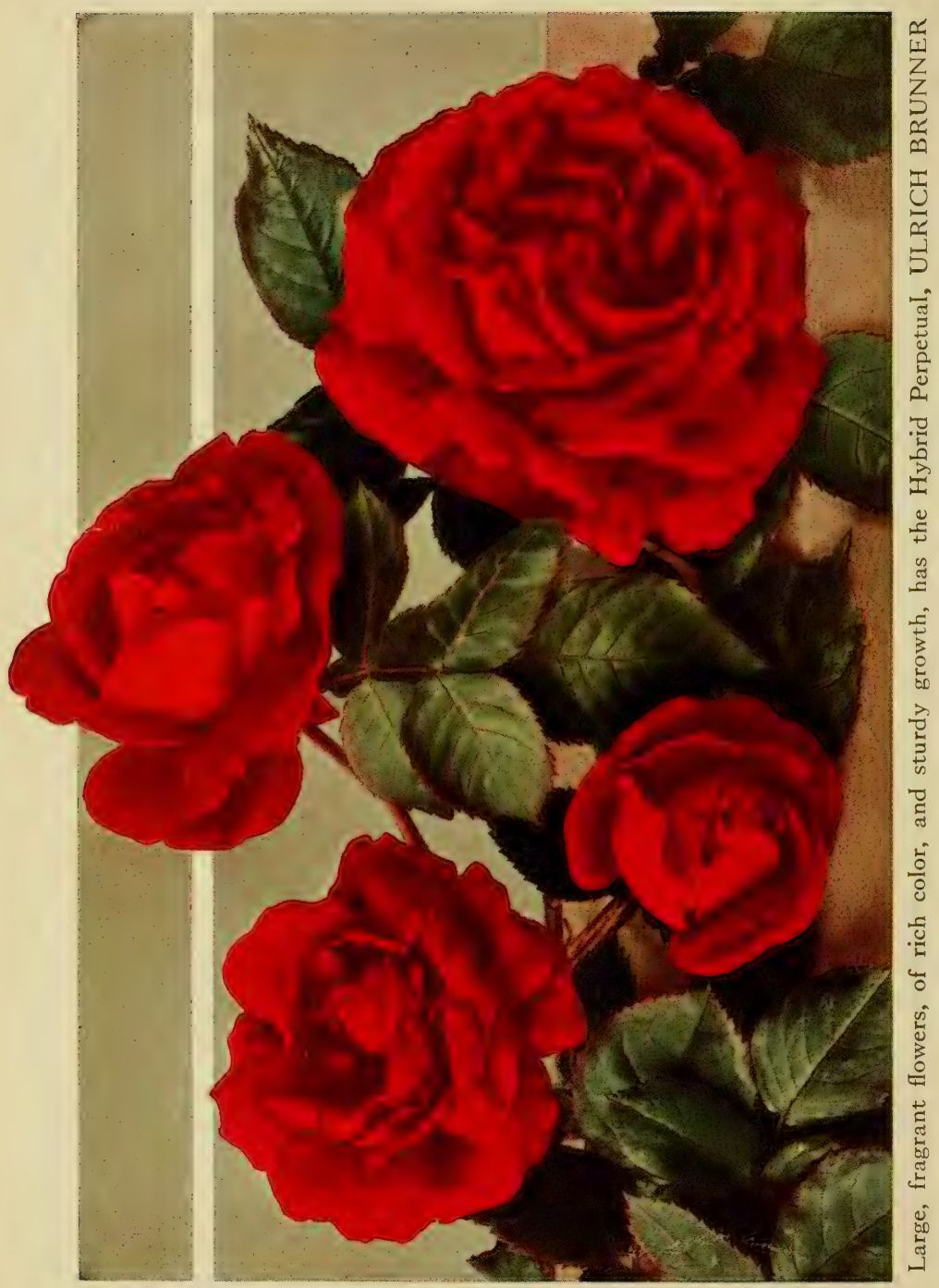




\section{Municipal Rose-Gardens}

Hartford, Connecticut, was the pioneer for America; and she builded well. Starting in 1904, in Elizabeth Park, there were laid out one and one-quarter acres. This the author visited first upon his return from a tour among the more prominent rose-gardens in England, Ireland, Holland, Germany, and France. While delighted with the cultural success and magnificent show of varieties, there seemed in the ensemble much to be desired in the matter of treatment and arrangement. This will probably be true of most of the testgardens referred to in the above section, because beauty of landscape effect is not the frrst thing sought for in a rosegarden made primarily for test purposes, although the more there is of grace and beauty, of charm and enchantment, by reason of the arrangement, of course, the better it is.

But Hartford led the way, and nobly continues to render this nation, at least the northeastern part of it, a great service. She showed that even a little public rose-garden, well done, begets enthusiastic public appreciation. Mr. G. A. Parker, Superintendent of Parks, of Hartford, reports I 6,000 people having visited this rose-garden in one year. There are in it three hundred different varieties of roses and about fifteen hundred separate plants, and the cost, both for construction and maintenance, in eleven years has been \$o.0I73 per visitor. But as for its influence upon, and value to, the people who have come to see it, no money estimates can be made. If any reader feels inclined to doubt this last statement, permit us to suggest that he submit his feelings to the test of a visit.

There are many American cities which have roses in their parks, and these cities are extending their plantings; but as yet only a limited number have definitely set apart, and regularly arranged for, a real rose-garden.

If any of our readers have the opportunity to visit PortIand, Oregon, certainly one of the sights of that city of wonderful promise is the municipal rose-garden. It is larger, perhaps, than that of Hartford, - a sunken garden with rose- 


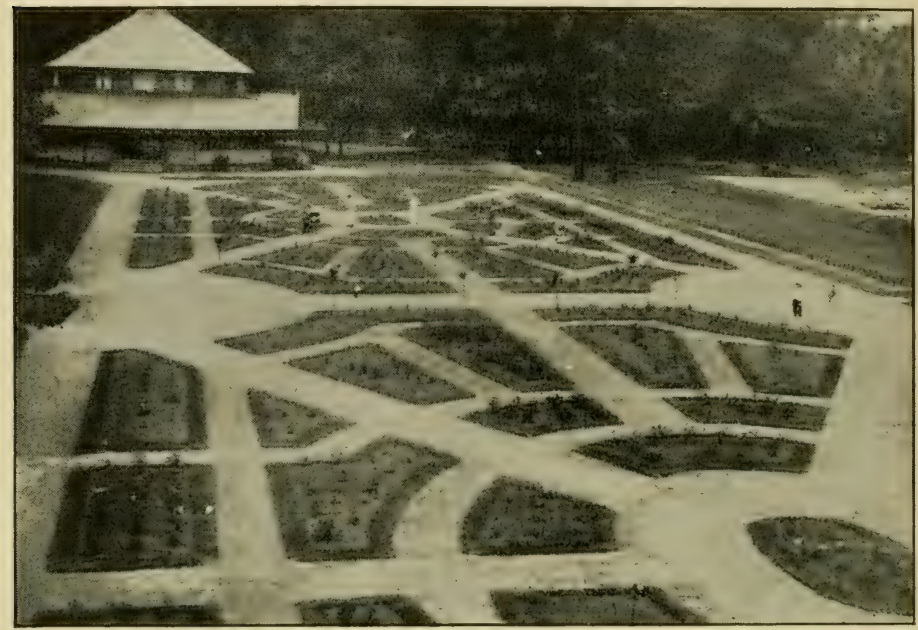

Municipal Rose-garden, Cleveland, Ohio. One year old

covered terraces; a fountain-centered system of walks and a large amount of growth; and, as nearly every rose-lover knows, a gratifyingly long season of bloom. It is, we believe, true of Portland, as of no other city, that the commercial men have long realized the value of the rose and its exploitation as an indirect, though very definite means of spreading, world-wide, the fame of that rose-favored corner of the earth. This is a reason why there is enthusiasm in Portland back of the conception to establish in another part of the city another municipal rose-garden that shall outclass any other in America. And why should Portland not do so? The author would enjoy telling his readers much more about the magnificent hedges of roses in Portland; of the great annual rosefestivals, with electrical displays; of many different parades; of automobiles; of the Royal Rosarians and their Queen of the Roses with her attendants,-all doing homage to the rose.

Last spring at Cleveland, Ohio, for the furst time there appeared, on display, a most creditable municipal rose-garden, its success being due in large measure, doubtless, to the able hand of their superintendent of parks. No climbing 
roses surrounded it when the author enjoyed its rich June bloom in 1915, but the varieties had been well chosen for that locality, and arranged in good taste. All were bush roses and were grouped in beds, with an arrangement of walks making the annually recurring display easily accessible to large numbers of people. Time and growth, with the good care it is sure to get, will furnish the softening and enriching effect that only age can supply. It is a splendid beginning, and such as one would expect of Cleveland.

And so, in sequence, might be mentioned a few other cities whose activities along this line have come to the attention of the author.

Syracuse, New York, has now the beginning of a most creditable municipal rose-garden, the result of a demand made by the citizens, promoted by an energetic rose society and its indefatigable president, Rev. E. M. Mills, D.D. Long life to him!

And this spring (19r6) will doubtless see the beginning of a real rose-garden in the Bronx Park system of New York City. The New York Horticultural Society and affiliated organizations have planned the establishment of a rose-planting that promises to rejoice the hearts of countless thousands of people. Let us all hope that it may be made easily accessible to those who most need the inspiration and pleasure which such a garden will be so well calculated to furnish. Compare with this of Paris the Municipal Rose-Garden of Minneapolis, illustrated page 28 .

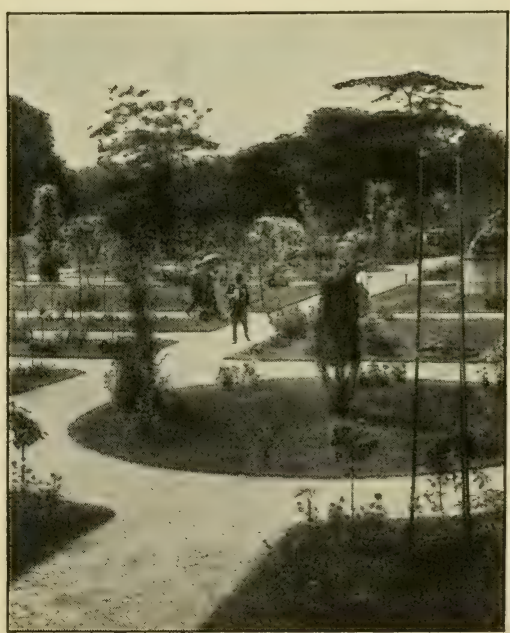

View in the Bagetelle Municipal Rose-garden, Paris 


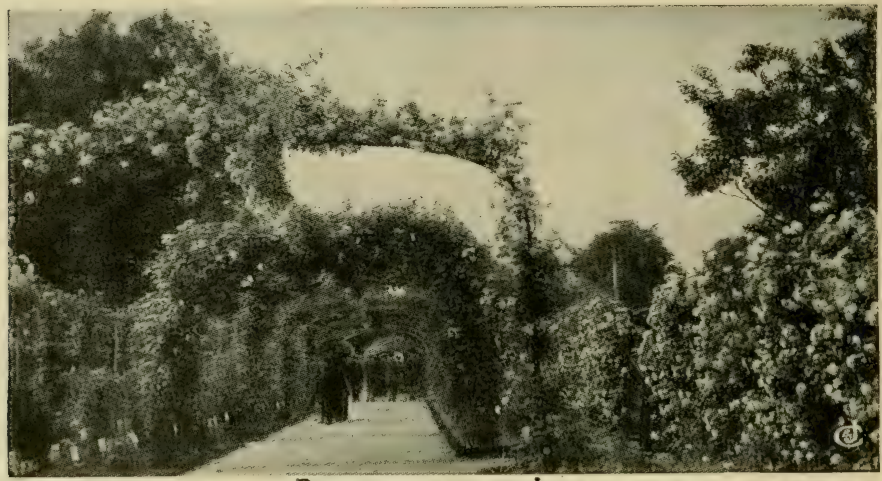

Roses, roses everywhere

\section{A Famous Rose-Garden}

The most beautiful rose-garden I have yet found in either America or Europe was near Paris. Accompanied by Mrs. Pyle, I arrived at the Roseraie de L'Hay early one day, and we lingered there till sunset, enchanted. A permanent rose-garden with thousands of varieties, it includes roses said to have originated in the sixth century B.C. Roses from every continent are arranged and trained in all imaginable styles, from borders of Baby Ramblers to giant Tree roses, is feet high and Io feet spread. Tunnels completely covered with climbing roses form outlooks through the garden, with here a bit of statuary, there a fountain flashing in the sunshine, with roses, roses everywhere, from the broad- 


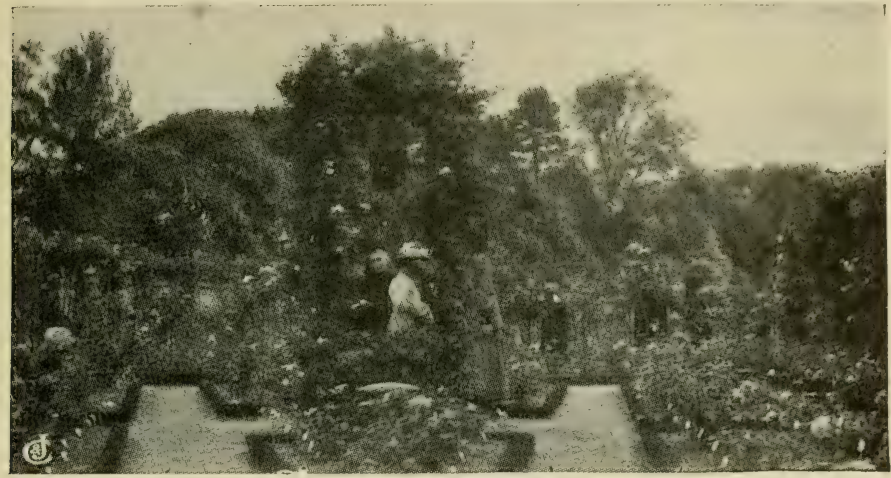

And here we lingered till sunset

petaled, deep red Lion climber to the splendid M. Gravereaux, named in honor of the owner of this magnificent garden. We strolled down the long, box-bordered pathways, with familiar faces among the roses looking up at us from beds at our feet, and climbers looking straight at us, and half-beckoning from either side, as we passed, until, spellbound, we stood and gazed down the long vista of colorcovered beds, back-bordered with still other climbers in bloom. And this is only one picture out of hundreds of such! What a love for the rose must have helped to fashion the quiet arbors and festooned balustrades, the archway entrances, artistic screens, and disappearing pathways, so well planned that every turn brought a fresh surprise, each one more entrancing than the other!

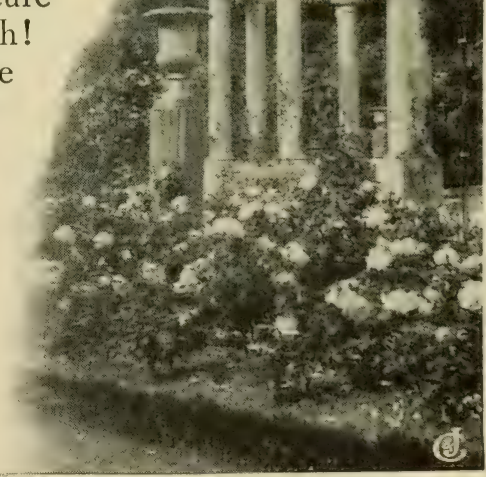

The Temple of Love 
Finally, so well hidden by an encircling temple of trees that we nearly missed it, was an open-air theater with turf seats, and along the front of the stage, for footlights, was a brilliant row of blooming roses. There, amid this paradise, in charming French fashion, our host entertained his guests with a musical recital. Can you wonder, therefore, that invitations to this garden are cherished?-for one can enter by invitation only. Write us, reader, when you are nearing Paris, and let us give you our card to this patron of roses, Mons. Jules Gravereaux, honored by Emperors.

[From notes and photographs taken by Robert Pyle, President of The Conard \& Jones Co., West Grove, Pa., on the occasion when he represented the American Rose Society and acted as judge at the International Contest of Garden Roses at Bagatelle, Paris, June, I9II.]

\section{The Red Rose Church at Manheim}

We know of no more unique ceremony in America than Manheim's "Feast of Roses." In I750, Baron Heinrich Wilhelm Stiegel, coming from Germany, settled in Lancaster County, Pennsylvania, and founded the little town of Manheim. He prospered in business and later deeded to the Lutheran congregation (which he organized in I769) a plot of ground for the erection of a house of worship with the following stipulation: "yielding and paying therefor at the said town of Manbeim, in the month of June, yearly forever after, the rent of ONE RED ROSE, if the same shall be lawfully demanded."

And now each year, with appropriate exercises, the congregation of the Manheim Lutheran Church pays to the heirs of Baron Stiegel the unique ground-rent of "one red rose," and each year recalls the memory of a man who, though "dying in poverty, had yet left the noblest of all memorials, the love, reverence, and gratitude of a community whose industry he had stimulated, whose ideals he had fostered, for whose spiritual welfare he had made permanent provision." (Published with the permission of the pastor, Rev. A. E. Cooper.) 


\section{Rose-Beads}

For the following formula the author is indebted to a good friend of his from New York State, whose experience in making rose-beads is far more extensive than his own.

"Gather the petals of roses-even newly fallen ones will do-till you have, say, half a peck. Grind these through a meat-chopper till they become pulp. In order to have the beads jet-black when finished, place this pulp in an iron pan, or, lacking that, mix in a teaspoonful of ground copperas (ferri sulphas), and stir thoroughly; the mixture will soon become brown. Set it now in the sun or a warm oven till it gets black. After this, put all through the meat-chopper again till it becomes like putty, and then form the beads. They can be made any shape you like,-round, square, hexagonal, etc.,but form them twice the size you wish to have them when finished. Rolling them into little balls with the hand will make smooth beads. If you wish them frgured, the buttend of a steel writing-pen is a convenient tool, to be used, of course, when the beads are still soft. When properly formed, transfix them to a board with a pin, then keep them hot and dry, and in two or three days they will become small and hard, and may be strung through the hole left when the pin is removed."

A European authority gives us a slightly different formula, and recommends using a mortar instead of the more prosaic and modern meat-chopper.

"Freshly gathered rose-petals are beaten into a pulp and then dried, but before becoming completely dry, rose-water is added and they are again beaten and dried, the operation being repeated till the pulp has become very smooth. Then the desired shape is given and they are perforated in order to thread them, and so a kind of bead is formed, which is dried. When they have become very hard, they are smoothed and polished, after which they are rubbed with oil-of-roses in order to give them more perfume and gloss. If a brass mortar be used, the pulp takes a deep black color, through the action on the metal of the gallic acid contained in the roses. On 
the other hand, if a marble mortar be used, blue and red and other colored beads can be manufactured according to the coloring materials employed. The black beads are most highly prized. They have been manufactured principally at Adrianople, Smyrna, and Constantinople."

\section{Attar of Roses}

The reader will notice on another page a short account of a visit made to that most beautiful rose-garden south of Paris, the Roseraie de L'Hay. Many chapters might be written of this little paradise about which clusters so much of interest to a rose-lover. But there is in that wonderful garden a quaint thatched "summer-house," as we in America might call it, rose-embowered. On the occasion of the author's visit, there was at work in the little cottage a white-aproned chemist with large-sized retort, test-tubes, spirit-lamps, and other appliances. The rose-petals which had been gathered in the garden were being reduced to essence or attar of roses. M. Gravereaux has improved the method of extracting the oils, and, furthermore, has proved by extensive experiments that certain perpetual-flowering roses, like Caroline Testout, and others, are capable of producing a much larger amount of the essence than the Damask and Centifolia roses heretofore largely used.

The method employed by M. Gravereaux is superior to that of the Bulgarians, Persians, and Algerians, whose apparatus is most primitive, as the following will indicate: The rose-petals must be distilled as they are picked, otherwise much of their odor will be lost. They are brought right to the stills, which are made of copper, and there mixed with only water, the quality of which is said considerably to influence the essence distilled. After having twice boiled down the mixture to one-eighth or one-tenth its original volume, it is allowed to cool, and is set in open bowls at a constant temperature. Gradually the essence rises and swims on the surface in yellowish patches, which are skimmed off with a mother-of-pearl spoon. This operation, usually falling upon 


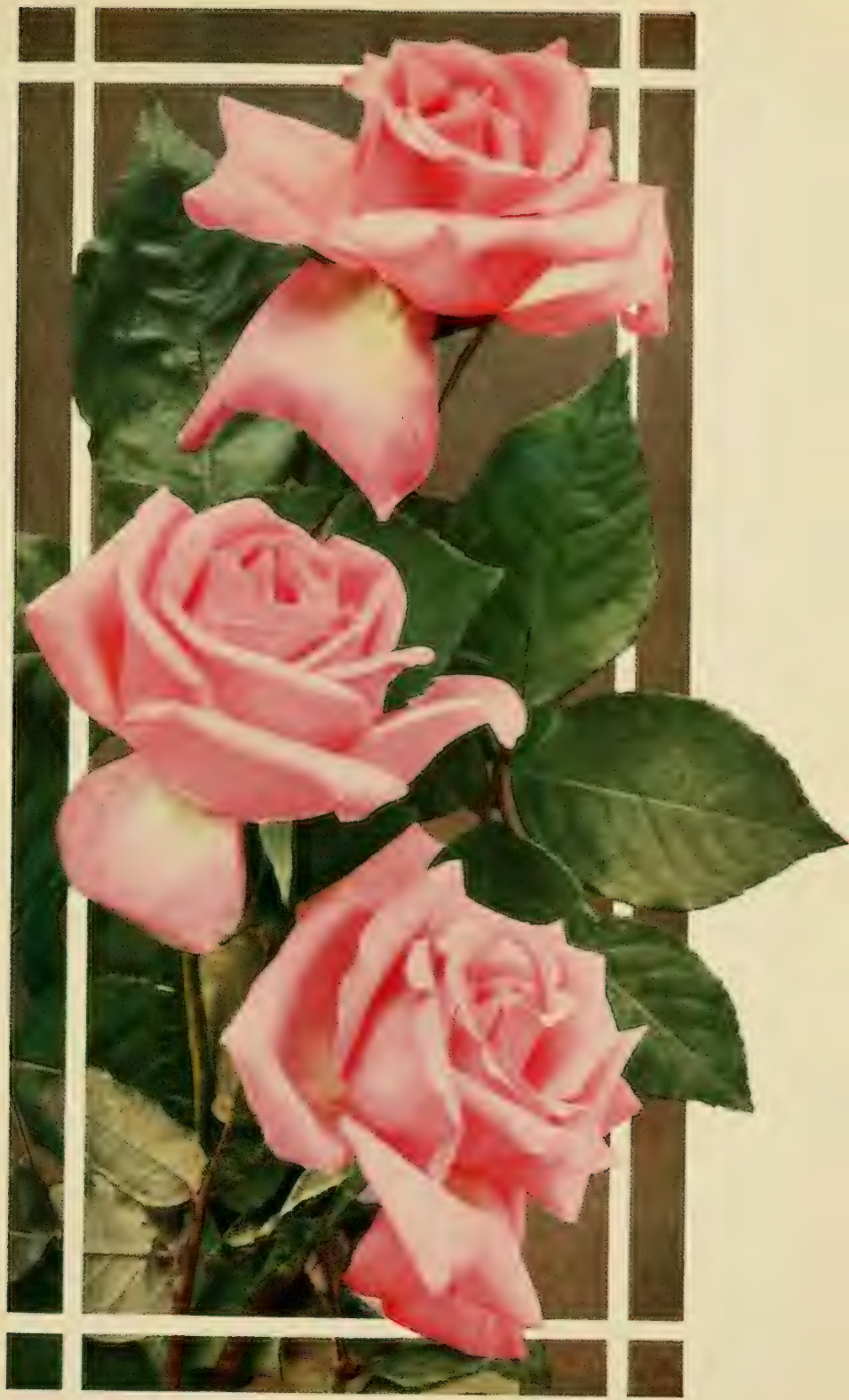

BRIDESMAID is most appropriately named, suggestive of what is best among the prettiest pink Tea Roses 
the eldest member of the family, is carried out with a solemnity befitting its importance. What this must mean to the peasants is better understood when we realize how feather-light rose-petals are, and that I50 pounds $(2,400$ ounces) of them ordinarily yield less than one ounce of the essence of the rose.

It is not to be marveled at, therefore, that it is expensive, not alone for the above reason, but aiso because of its importance in the fabrication of the frnest perfumes. It has, furthermore, the valuable quality of increasing and frxing other perfumes, just as the rose itself has the quality of developing in those who work with it qualities of fine moral character.

\section{Hybridizing}

This book attempts in no way to cover the subject of hybridizing, save to refer to some sources of information regarding a work that calls for long-sustained attention, and almost limitless patience, with no assurance as to results. Amateurs, as well as professional rose-growers, have made valuable contributions to our lists of roses, and certainly the future must offer more adequate recompense to the successful breeder of roses than has been the case in the past.

Rev. Joseph H. Pemberton*, for the beginner, gives directions that appear to be easily followed by one who has the time and facilities to undertake the work.

Every hybridizer will be interested also in the articles by Dr. White and Dr. Van Fleet in "The American RoseAnnual" for I9I6; also in the "Stammbuch der Edelrosen," by Dr. G. Kruger. The edition of this work, published in I906, at Trier, Germany, contains a most complete listing of the hybridized roses in commerce, including parentage, hybridizer, and date of issue. For example, under Caroline Testout, are given fifty-eight immediate descendants, showing also the name of the other parent in all except nine cases. It would seem to be an invaluable work for anyone who wishes to undertake hybridizing.

* "Roses," page 229 (see Bibliography). 


\section{Bibliography}

Beginning with "The Rose Manual," by Robert Buist, in I884, there have been issued in America at least eighteen different works, the most noteworthy of which we list below: The Rose. By H. B. Ellwanger. I882. 293 pp. Dodd, Mead \& Co., New York. This was long the standard rose book.

A Book about Roses. By S. Reynolds Hole. 1883. 326 pp. Wm. S. Gottsberger, New York. An American reprint of a standard English work. Highly entertaining work on roses, and most inspiring.

Roses and How to Grow Them. Collected magazine articles. I9io. I99 pp. Doubleday, Page \& Co., Garden City, N. Y.

Commercial Rose-Culture. By Eber Holmes. igi i. i65 pp. A. T. De Ia Mare Printing and Publishing Company, New York.

Making a Rose-Garden. By H. H. Saylor. I9I2. 53 pp. McBride, Nast \& Co., New York.

Everblooming Roses for the Outdoor Garden. By Georgia T. Drennan. 1912. 262 pp. Duffield \& Co., New York.

The Practical Book of Outdoor Rose-Growing. By George C. Thomas, Jr. 1914. 156 pp. and 96 plates in color, etc. J. B. Lippincott Company.

The American Rose Annual. 19i6. Published by the J. Horace McFarland Company, Harrisburg, Pa., for The American Rose Society. Contributions upon roses, rose-growing and rose-gardens. Recounts the year's activities. Free to members, or may be had in paper binding from the publisher at 50 cents each, while they last.

The following are all edited from the English standpoint:

Roses: Their History, Development, and Cultivation. By Rev. Joseph H. Pemberton, Vice-President of the National Rose Society. 1908. 336 pp. Longmans, Green \& Co., London and New York.

Roses and Rose-Growing. By Rose G. Kingsley. I908. I63 pp., 28 full-page color-plates. The Macmillan Company, New York and London. With special attention to the best roses in each of the various classes, regarded from the English viewpoint.

Roses for English Gardens. By Gertrude JekyII and Edward Mawley. 1902. I64 Pp. George Newnes, Ltd., London. Although relating to English gardens, it is, nevertheless, most entertaining, and by its thoroughness helps to clear up many questions left unanswered by other authorities.

Rose-Growing Made Easy. By E. T. Cook. 200 pp. Another English publication, suggestive and helpful, and written apparently by one with long years of first-hand experience.

THE ROSE BOOK. A complete guide for amateur rose-growers by $\mathrm{H}$. $\mathrm{H}$. Thomas. I913. $283 \mathrm{pp}$. Profusely illustrated. Treats well the various uses to which roses may be put.

For a list of rose books in all languages the "Cyclopedia of American Horticulture" refers us to the "Bibliografia de Ia Rosa," Vergara, Madrid, I892. 


\section{Synonymous Roses}

Some roses have acquired new names that seem to be an improvement; for example, Dutch Beauty in place of Veluwezoom. Another case is Mme. Norbert Levavasseur; when once planted and thoroughly domesticated, she answers to the name of Red Baby Rambler. But, if you wish to order Red Baby Rambler, remember there are nearly half a dozen roses so called; so, if you want to be certain, refer to the following list for guidance. Renaming a rose with intent to deceive has come to be regarded by rosarians as a crime. When a second name is adopted for the sake of euphony, the original name should be carried in parentheses.

Anna de Diesbach

Baby Dorothy, Pink

Baby Rambler, Pink

Baby Rambler, Red

Baby Rambler, White

Baby Rambler, Yellow

Baby Tausendschön

Baby Tausendschön

Ball of Snow

Dorothy Dennison.

Dorothy Perkins

Dorothy Perkins, Red

Dutch Beauty

Green Rose

Killarney, Striped

Killarney, Orange

La France, Red

La France, Striped

La France, White

La Reine des Neige

Magnolia Rose

Maman Cochet, Yellow

Maman Levavasseur

Mignon

Mrs. W. H. Cutbush

Mrs. W. J. Grant

Prima Donna

Prince Camille de Rohan

Queen, The

Rambler, Golden

Rambler, Pink

Rambler, White

Rambler, Yellow

Sweetheart

Thousand Beauties

Virginia R. Coxe

White American Beauty

Wm. R. Smith

Wm. R. Smith
H.P.

P.

P.

$\mathrm{P}$

$\mathrm{P}$.

P.

$\mathrm{P}$.

$P$.

H.P.

W.

H.W.

H.W.

H.T.

C.

H.T.

H.T.

H.T.

H.T.

H.T.

H.P.

$T$.

H.T.

$\mathrm{P}$.

P.

P.

H.T

H.T.

H.P.

$\mathrm{T}$.

N.

Mult.

Mult.

Mult.

P.

Mult.

H.T.

H.P.

$\mathrm{T}$.
Gloire de Paris

Maman Levavasseur

Maman Levavasseur

Mme. Norbert Levavasseur

Katherine Zeimet

Etoile de Mai

Louise Walter

Echo

Perle des Blanches

Lady Godiva

Lady Gay

Excelsa

Veluwezoom

Viridiflora

Spectacular

Duchess of Wellington

Duchess of Albany

Mme. Angel Vayssett

Mile. Aug. Guinoisseau

Frau Karl Druschki

Devoniensis

Mme. Derepas-Matrat

Baby Dorothy

Cecile Brunner

Mrs. Taft

Belle Siebrecht

Mme. P. Euler

La Roseire

Souv. de S. A. Prince

Alister Stella Gray

Euphrosine

Thalia

Aglaia

Cecile Brunner

Tausendschön

Gruss an Teplitz

Frau Karl Druschki

Charles Dingee

Jeannette Heller

N.B.-See also common names to rose species, foot of page 107. 


\section{Analysis of Species}

It is doubtful if anyone will have come thus far in this little book, who is not, with the author, a real seeker after truth. Just as the story of man becomes doubly interesting as we trace back his development from the earlier types of man, so with the rose. A present-day Radiance or Rayon d'Or is a vastly more fascinating object of attention when one can go to another corner of the garden and point out to visitors the true progenitor of that race. Hybridizing deserves a complete chapter of its own. Right here let us study what bas been done by the guiding hand of man. Family charts are a useful aid in pointing out relationships. A diagram may be more illuminating than many pages of description. Therefore, as an introduction to the various best-known classes, pause a moment to survey* this analysis of species on the two following pages. This the author conceives to be a most helpful outline of the many, many families that make up this interesting race of flowers.

In this book there has not been room to describe the rose species. We would, however, call special attention to certain "types" which we have starred in the following list. Their place is not in a bed with the Teas or Hybrid Teas. Consider for example, Hugonis-that recent acquisition from China. In three seasons it will be 4 to 5 feet high and in bloom two weeks earlier than the early-blooming Harison's Yellow. And so with others: they are unique, hardy, vigorous. They need only to be fittingly placed to give to the garden a charm and distinction quite above the ordinary.

* The following two pages are published here with permission and by courtesy of Longmans, Green \& Co., New York., from their book, "Roses: Their History, Development, and Cultivation," by Rev. J. H. Pemberton (see page 105).

The reader will note how far removed from the original species are both the Tea and Hybrid Tea families, whereas, from many species there has been almost no development at all.

Equivalents of our common names to some of those on next pages: 


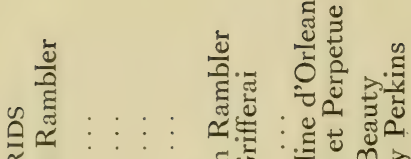

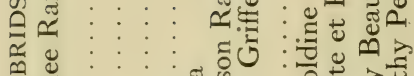

\&

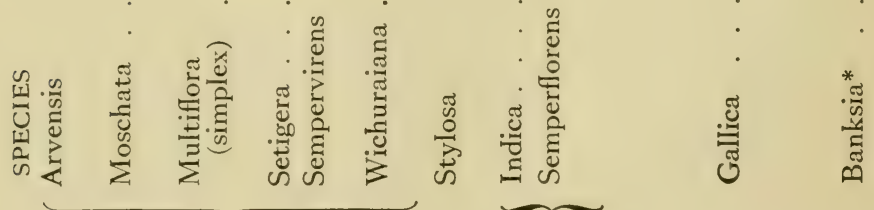

$\sum_{\frac{1}{0}}^{z}$ 


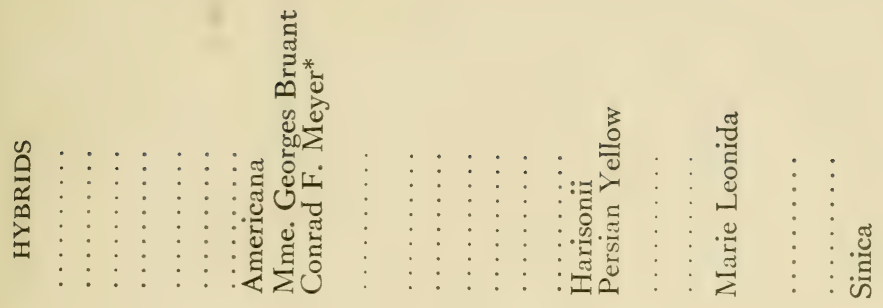

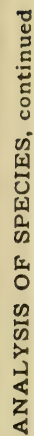

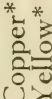

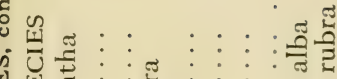

जิ

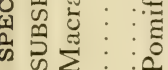

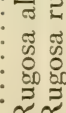

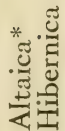

E

.

w
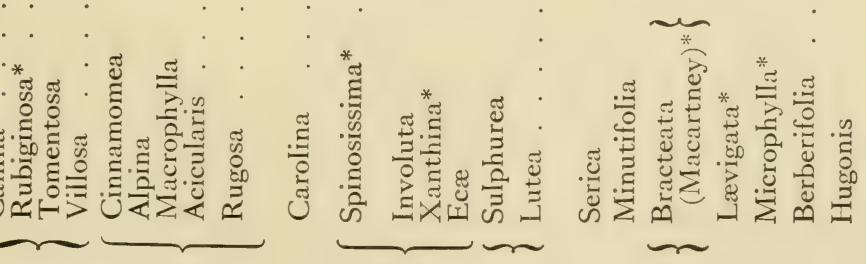

总

हี

.

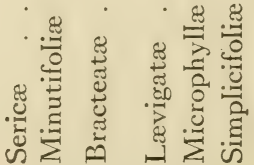




\section{Roses Arranged in Classes}

In order that the various classes may be studied better as to their characteristics, we hereunder group the more important varieties. French, German, and English authorities differ somewhat in placing a few kinds. Regarding the following lists, however, they are in substantial agreement. In case of differences we have relied upon the country of origin as our authority, e.g., Harison's Yellow.

\section{Austrian Briar, or Lutea}

Austrian Copper

Austrian Yellow
*Harison's Yellow

*Persian Yellow

\section{Hybrid Austrian Briar, or Pernetiana}
*Beaute de Lyon
*Constance
Juliet
*Louise Catherine
Breslau
* Mme. Edouard Herriot
*Muriel Dickson
*Rayon d'Or
*Soleil d'Or

\section{Bengal}

Archduke Charles

Douglas
Lucullus

Maddalena Scalarandis

\section{Bourbon}

Appoline

*Beauty of Rosemawr Burbank

Agrippina

*Hermosa
*Champion of the World

*Mme. Eugene Marlitt

Santa Rosa

*Souv. de la Malmaison

\section{Cbina}

Pink Daily

*Queen's Scarlet

Viridiflora†

\section{Damask}

Mrs. O. C. Orpen *York and Lancaster

Hybrid Perpetual

Alfred Colomb

Alphonse Soupert

American Beauty

*Anna de Diesbach $\dagger$

Antoine Wintzer
Ards Rover

Ball of Snow

Barbarossa

Baroness Rothschild

Baron de Bonstetten
Belle d'Orleans

*Candeur Lyonnaise

Captain Christy

Captain Hayward

Charles Wagner

\section{REFERENCE MARKS EXPLAINED}

The asterisk $(*)$ indicates leading varieties described on pages 43 to 62 .

The dagger $(\dagger)$ indicates roses with two names and refers to list of synonymous roses. 


Cheshunt Hybrid
*Clio
Commander Jules
Gravereaux
Coquette des AIpes
Coquette des Blanches
*Coronation
Eugene Furst
Francois Levet
*Frau KarI Druschki†
*General Jacqueminot
George Arends
Giant of Battles
*Gloire de Chedane
Guinoisseau
Gloire de Margottin

Admiral Schley

Admiral Ward

*Antoine Rivoire

*Arthur R. Goodwin

Augustus Hartman

Autumn Tints

Belle Siebrecht

Bessie Brown

Betty

*Brilliant

British Queen

Camoëns

Cardinal

Carine

*Chateau de Clos Vougeot

Cherry Page

Cherry Ripe

Chrissie MacKellar

Cissie Easlea

Cleveland

Colleen

Col. R. S. Williamson

Comtesse Icy Hardegg

*Countess Clanwilliam

Countess of Derby

Countess of Gosford

Countess of Shaftesbury

Dean Hole

Defiance

Dorothy Page-Roberts

Dr. J. Campbell Hall

Dr. O'Donel Brown

Duchess of Albanyt

Duchess of Sutherland

*Duchess of Wellington $\dagger$

Duchess of Westminster

Hybrid Perpetual Roses, continued

*Gloire Lyonnaise

Glory of Paris

Heinrich Munch

*Hugh Dickson

*J. B. Clark

John Hopper

John Keynes

Jubilee

Lady Helen Stewart

La Reine

Mme. Charles Wood

Mme. Masson

Mlle. Louise Crette

*Magna Charta

Marchioness of Lorne

Margaret Dickson

$$
\text { Hybrid Tea }
$$

EarI of Warwick

* Ecarlatè

Edgar M. Burnett

Edith Part

Edward Mawley

Elizabeth Barnes

Ethel Malcolm

*Etoile de France

Eugene Boullet

Florence E. Coulthwait

Florence Forrester

*Florence Pemberton

Francis Scott Key

F. R. Patzer

Frau Lila

Rautenstraugh

Gainsborough

G. Amedee Hammond

* General MacArthur

*General-Superior Arnold Janssen

George C. Waud

*George Dickson

Gorgeous

Grace Molyneux

*Gruss an Teplitz†

Gustav Grunerwald

Hadley

Hector MacKenzie

Helen Gould

H. E. Richardson

*Hoosier Beauty

H. V. Machin

Ideal

Iona Herdman

Irish Beauty

*Irish Elegance

Irish Fireflame

James Coey

Janet
Marshall P. Wilder

*Mrs. John Laing

Mrs. R. G. SharmanCrawford

Oakmont

Paula Clegg

*Paul Neyron

* Prince Camille de Rohant

Rembrandt

*Roger Lambelin

Tom Wood

*Ulrich Brunner

Vick's Caprice

Victor Verdier

*Jonkheer J. L. Mock

*Joseph Hill

Josephine

*Kaiserin Augusta Victoria

*Killarney

* Killarney Brilliant

Killarney, White

Killarney Queen

King George V.

Königin Carola

*Lady Alice Stanley

Lady Greenall

*Lady Mary Ward

Lady Moyra Beauclerc

Lady Pirrie

Lady Ursula

* La France $\dagger$

* La Tosca

*Laurent Carle

Leslie Holland

Liberty

Lieutenant Chaure

Louise Lilia

*Lyon Rose

Mme. Abel Chatenay

Mme. Bernier d'Arnex

*Mme. Caroline Testout

*Mme. Chas. Lutaud

Mme. Colette Martinet

(Mme. DerepasMatrat)

*Mme. Edmond Rostand

Mme. Eugenie Boullet

Mme. Felix Faure

Mme. Jenny Guillemot

Mme. Jules Bouche

*Mme. Jules Grolez

Mme. J. W. Budde 


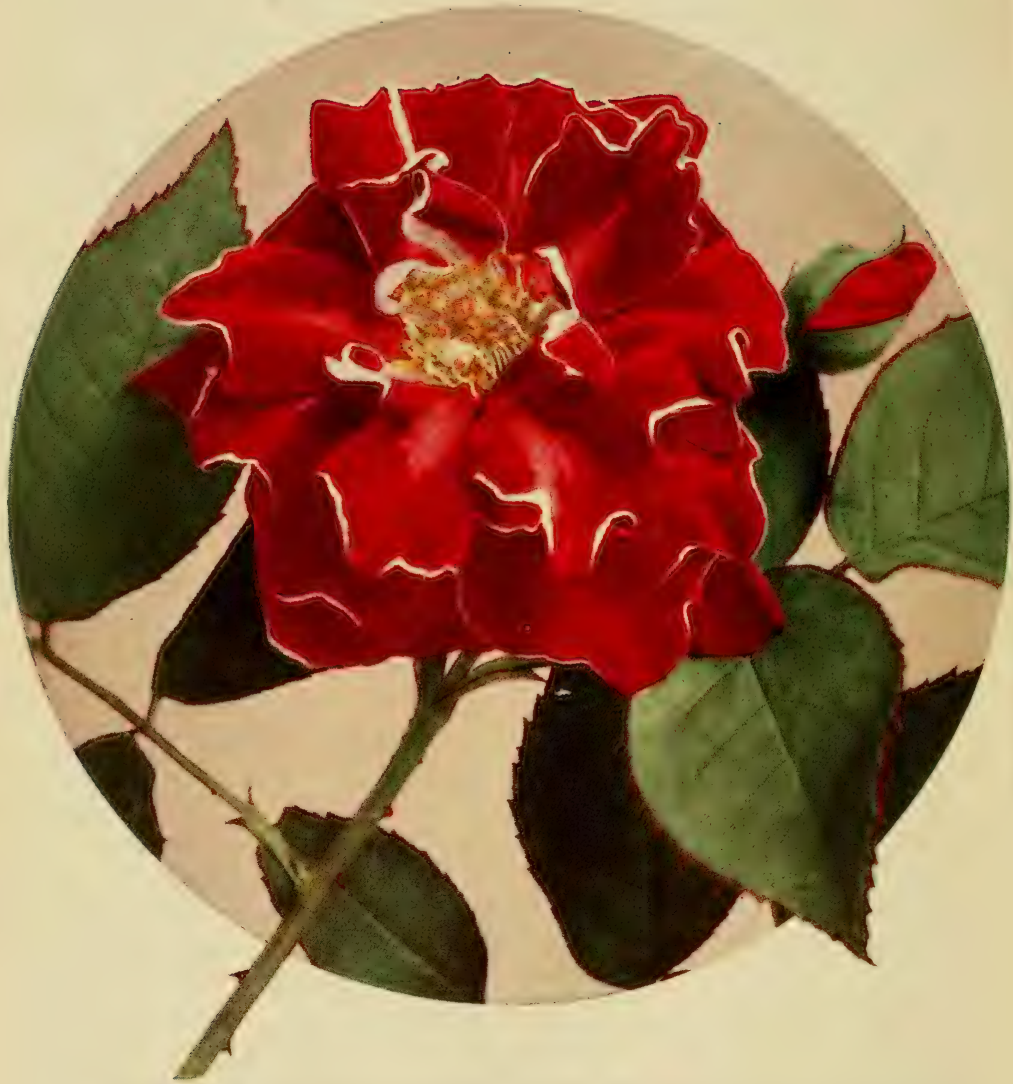

It is curious that this charming though extremely odd-looking variety should be so little known and less grown. It has scalloped petals of deep crimson, narrowly edged with white, reminding one of the Cross of the Legion of Honor. This Rose, ROGER LAMBELIN, is a rare and unique member of the Hardy Hybrid Perpetual family. 
Hybrid Tea Roses, continued

*Mme. Leon Pain

Mme. Maurice de Luze

*Mme. Melanie Soupert

Mme. P. Euler

Mme. Phillip Rivoire

*Mme. Ravary

Mme. Schwaller

*Mme. Segond Weber

Mlle. Aug. Guinoisseau

MIle. Helena Gambier

MIle. Marie Mascurand

Mabel Drew

Magnafrano

Mama Looymans

Marcella

*Margaret Dickson Hamill

Mark Twain

Marquise de Querhoent

*Marquise de Sinety

*Mary, Countess of IIchester

Max Hesdorffer

May Miller

Meteor

Mevrouw Dora Van Tets

Milady

*Miss Cynthia Forde

*Mrs. Aaron Ward

Mrs. A. E. Coxhead

Mrs. Ambrose Riccardo

Mrs. Amy Hammond

Mrs. Andrew Carnegie

Mrs. Archie Gray

*Mrs. A. R. WaddeII

Mrs. Bertram T. Walker

Mrs. Chas. E. Pearson

Mrs. Chas. Hunter
Mrs. Chas. Russell

Mrs. Conway Jones

Mrs. Cornwallis West

Mrs. David Jardine

Mrs. David McKee

Mrs. Edward Powell

Mrs. Forde

Mrs. F. W. Vanderbilt

Mrs. George Gordon

Mrs. George Norwood

Mrs. George Shawyer

Mrs. Harold

Brocklebank

Mrs. Harvey Thomas

Mrs. Hugh Dickson

Mrs. J. H. Welsh

Mrs. MacKellar

Mrs. Maynard Sinton

Mrs. Moorefreld Storey

Mrs. R. D. McClure

Mrs. Richard Draper

Mrs. Robert Garrett

Mrs. Sam Ross

Mrs. T. Hillas

Mrs. Theo. Roosevelt

*Mrs. WakefieId Christie-Miller

Mrs. Wemyss Quin

*My Maryland

Natalie Bottner

Neervelt

Nerissa

Old-Gold

Oliva

*Ophelia

Panama

Peerless

Pernet's Triumph

Pharisäer
President Vignet

Prima Donnat

Prince Charles d'Arenburg

Prince of Bulgaria

Princess Bonnie

Queen Beatrice

Queen Mary

*Radiance

*Rayon d'Or

Red-Letter Day

Reine Carola de Saxe

Reine Marguerite d'Italie

Rene Robbins

Renee Wilmart Urban

*Rhea Reid

Richmond

Sea-Bird

Souv. de E. Guillard

*Souv. de Gustav Prat

Souv. du Pres. Carnot

Souv. of Wootton

Spectaculart

*Sunburst

*Taft Rose

Veluwezoom $\dagger$

Viscountess Enfield

Virginia R. Coxet

Walter Speed

Waltham's Scarlet

W. E. Lippiatt

Wellesley

West Grove

*White Killarney

William Cooper

*William Shean

*Willowmere

Winnie Davis

There are in this list other promising varieties not yet sufficiently tested to recommend.

*Blanche Moreau

Blanche Roberts

Caroline Marneis

Comtesse de Murinais

Ænnchen Müller

*Baby Dorothy $\dagger$

Baby Ramblert

Betsy Van Nes

*MIle. Cecile Brunner

Clothilde Soupert

Echo

\section{Moss}

*Crested Moss

Crimson Globe

Eugene de Savoi

*Glory of Mosses

\section{Polyantha}

*EIIen Poulsen

*Erna Teschendorff

Etoile de Mai

George EIger

Goldfinch

*Gruss an Aachen

Katherine Zeimet
*Henry Martin

Mousseline

*Princess Adelaide Salet

*Leonie Lamesch

*Louise Walter $\dagger$

*Mme. Norbert Levavasseurt

* Maman Levavasseur

*Marie Pavie

Mignon $\dagger$ 
Mignonette

Miniature

Mosella, T.P.

Mrs. W. H. Cutbush $†$

Mme. Jules Gouchault

Polyantba Roses, continued

Mrs. Taft $\dagger$

*Orleans

Perle d'Or

Sweetheart $\dagger$

*Tip-Top
Triomphe d'Orleans

White Soupert

Yellow Soupert

Yvonne Rabier
Agnes Emily Carmen

Alice Aldrich

Amelia Gravereaux

Beaute Poitevine

*Blanche Double de Coubert

Chas. F. Worth

*Conrad Ferdinand Meyer

Ada Carmody

*Alexander Hill Gray

Alliance Franco-Russe

Anna Oliver

Aurora

Beaute Inconstante

Betty Berkeley

Blumenschmidt

Bon Silene

Bride

*Bridesmaid

Canadian Belle

Catherine Mermet

Comtesse Riza du Parc

Comtesse Sophy Torby

Coquette de Lyon

Corallina

Corinna

Cornelia Cook

David Pradel

*Devoniensis $\dagger$

Dr. Grill

*Duchesse de Brabant

Enchantress

*Etoile de Lyon

Fr. von Marschall

General R. E. Lee

G. Nabonnand

Golden Gate

*Harry Kirk

*Helen Good

Henry M. Stanley

*Hugo Roller

Isabella Sprunt

Ivory

\section{Rugosa}

Hansa

Mme. Chas. Frederick Worth

Magnifica

*New Century

Nova Zembla

Regina Badet

Repens alba

*Roseraie de L'Hay

\section{Tea}

J. B. Varonne

Königin Wilhelmina

*Lady Hillingdon

Lady Plymouth

Lady Roberts

Lena

Letty Coles

Mme. Antoine Mari

*Mme. Camille

Mme. Caroline Kuster

Mme. C. P. Strassheim

Mme.Derepas-Matrat

Mme. de Vatrey

Mme. de Watteville

Mme. Elie Lambert

Mme. F. Kruger

Mme. Hoste

Mme. Jean Dupuy

Mme. Jos. Schwartz

Mme. Lambard

Mme. Margottin

Mme. Olga

Mme. Rene Gerard

Mme. Vermorel

Mme. Welche

MIle. J. Phillips

*Madison

*Maman Cochet $\dagger$

*Maman Cochet, White

*Marie Guillot

Marie Lambert

*Marie Van Houtte

Marion Dingee

Medea

Bengal, Climber

Empress of China
Roseraie Parfum de L' Hay

Rosa Tetankaba

*Rugosa alba

*Rugosa rubra

*Sir Thomas Lipton

(White Century)

Souv. de Pierre

Leperdrieux

*Miss Alice de

Rothschild

*Molly S. Crawford

*Mrs. B. R. Cant

Mrs. Campbell HalI

Mrs. Foley Hobbs

Mrs. Herbert

Hawksworth

*Mrs. Herbert Stevens

Mrs. Hubert Taylor

Mrs. Myles Kennedy

Mrs. S. T. Wright

Muriel Grahame

Nita Weldon

Papa Gontier

*Perle des Jardins

Perle des Jaunes

Princess Hohenzollern

Princess de Sagan

Queen Olga of Greece

Queen, The†

Rainbow

Rose d'Evian

*Safrano

Sombrieul

Souv. de Catherine Guillot

*Souv. de Pierre

Notting

Sulphurea

* Sunrise

Sunset

White Maman Cochet

${ }^{*}$ Wm. R. Smith $\dagger$

Winter Gem 
Climbing Hybrid Teas

Belle Siebrecht

Carmine Pillar (Paul's)

* Gruss an Teplitz, Climbing

Kaiserin Augusta Victoria, Climbing

Killarney, Climbing
Killarney, White, Climbing

La France, Pink, Climbing

Mme.Caroline Testout, Climbing

Mme. Wagram
Cumberland Belle
Meteor, Climbing

My Maryland, Climbing

Reine Marie Henriette, Climbing

Souv. of Wootton, Climbing

\section{Climbing Moss}

\section{Multiflora}

Aglaia

*American Pillar

*Birdie Blye

Flower of Fairfield

Geisha

*Alister Stella Gray†

Bridesmaid, Climbing

Chromatella $\dagger$

Cloth of Gold $\dagger$

Cecile Brunner, Climbing
Miss Messman

Mosella, Climbing

*Philadelphia Rambler

Psyche

Rambler, Crimson

Noisette

Lamarque

Mme. Alfred Carriere

*Marechal Niel

Climbing Polyantha

Clothilde Soupert,

Climbing

Wichmoss

\section{Sweetbriar}

*Amy Robsart

*Anne of Geierstein
Ramblers $†$

*Tausendschön†

Thalia

Trier

Wartburg

Reve d'Or

Solfaterre

*Wm. Allen Richardson

\section{Climbing Tea}

Devoniensis, Climbing

Gloire de Dijon

Isabella Gray

James Sprunt
Mme. Driout

Mine. Jules Gravereaux

Maman Cochet, Pink, Climbing
* Lady Penzance

*Sweetbriar, Common
Frau Berta Guertler, Climbing 


\section{Index}

Acicularis, 109.

Ada Carmody, 114 .

Admiral Aaron Ward, 8r.

Admiral Aaron Ward Rose I 1 .

Admiral Schley, 11 r.

Ænnchen Muller, I 13.

Aglaia, 108, II 5 .

Agnes Emily Carmen, I 14 .

Agrippina, I 10.

Alba, 108.

Alba rubrifolia, II 5 .

Alberic Barbier, 43.

Alexander Hill Gray, 43.

Alfred Colomb, I I 0 .

Alice Aldrich, I 14.

Alister Stella Gray

(Golden Rambler), 43.

Alliance Franco-Russe, I 14.

Alphonse Soupert, r I 0 .

Alpina, rog.

Altaica, rog.

Altitude, Consideration of, 6.

Americana, rog.

Amelia Gravereaux, 114 .

American Beauty (Mme. Ferd. Jamin), I 10.

American Beauty, Climbing, 43 .

American Pillar, 44.

American Rose Society, 92.

Amy Robsart, 44 .

Analysis of Species, 107109.

Anna de Diesbach, 44.

Anna Oliver, I I 4.

Anne of Geierstein, 44.

Antoine Rivoire, 44.

Antoine Wintzer, I ro.

Aphides or green-fly, How and when to destroy, $6,30$.

Appoline, I Io.

Archduke Charles, I ro.

Ards Rover, I1 0.

Arsenate of lead, How to use, 6.

Arthur R. Goodwin, 44.

Arvensis, 108.

Ashes, Use of Coal, 6.

Attar of Roses, 102 .

Avenue effect with roses, I3.

Augustus Hartman, I I I .

Aurora, I1 4 .

Austrian Copper, 109, I 10.

Austrian Yellow, 109, I 10.

Autumn Tints, III.

Aviator Bleriot, 115 .

Ayrshire, 108.

Baby Dorothy (Maman Levavasseur), 44, 106.

Baby Rambler, Crimson (Mme. Norbert Levavasseur), 44 , 106.
Baby Ramblers, 44, 106.

Baby Tausendschön (Louise Walter), 106.

Bailey, Prof. Liberty H., 38.

Ball of Snow, 106, x 10.

Banksiæ, 108.

Banksia, 108.

Barbarossa, i 1 o.

Baron de Bonstetten, I 10.

Baroness Rothschild, I 10.

Beaute de Lyon, 44.

Beaute Inconstante, II 4 .

Beaute Poitevine, II 4.

Beauty of Rosemawr, 44 .

Beds, Rose, shape and size, II.

Belle d'Orleans, i ro.

Belle Siebrecht, 1 I I.

Belle Siebrecht, Climbing, I 5 .

Berberifolia, 109.

Bessie Brown, I I I.

Betsy Van Nes, I 13.

Betty, I I I.

Betty Berkeley, I 14 .

Bibliography, 105.

Birdie Blye, 44.

Black-spot, 30 .

Blanc Double de Coubert, 44 .

Blanche Moreau, 44 .

Blanche Roberts, I I3.

Blumenschmidt, I 4 .

Bone-dust, When to use, 17.

Bon Silene, I 14 .

Books about roses, 105.

Bourbons, 108.

Bracteata, rog.

Bracteatæ, Io9.

Bride, I I 4 .

Bridesmaid, 44.

Bridesmaid, Climbing, 1 I 5 .

Brilliant, 44.

British Queen, I I I.

Bruant, M. Georges, 86.

Brunoni, I 08.

Budded roses, 36.

Bi:d-rot, 30.

Burbank, I 10.

Burying roses for winter, 27.

Cabbage, 108.

Calendar of operations, 6,7 .

Camoëns, III.

Canadian Belle, II 4.

Candeur Lyonnaise, 44.

Canina, rog.

Canina roses for grafting, 36.

Caninæ, rog.

Captain Christy, 110.

Captain Hayward, IIo.

Cardinal, 111 .
Carine, I I I.

Carmen, Robert C. S., 86.

Carmine Pillar, I 15 .

Carolina, rog.

Carolinæ, rog.

Caroline Marneis, II3.

Catherine Mermet, II4.

Cassimer Moulle, II 5.

Cecile Brunner, 44.

Cecile Brunner, Climbing, I 5 .

Centifolia, 108.

Champion of the WorId, 46.

Chapman, Mr., ornithologist, 10.

Charles Dingee, 106.

Charles F. Worth, II 4 .

Charles Wagner, I10.

Chateau de Clos Vougeot, 46.

Cherry Page, II I.

Cherry Ripe, Ir

Cheshunt Hybrid, II I.

Chinas, ro8.

Chrissie MacKellar, II I.

Christine Wright, 46.

Cinnamomea, rog.

Cissie Easlea, i 1 1.

Classes of Roses, 39, 1 roI 5 .

Cleveland, $\mathrm{I}$ I 1 .

Clio, 46.

Clothilde Soupert, I 13

Clothilde Soupert, Climbing, 115.

Colleen, 1 I 1 .

Color plates, 1, 12, 21, 32 , $40,45,51,58,63,70,78$, $87,94,103,112,117$.

Col. R.S. Williamson, i i 1 .

Commander Jules Gravereaux, I I I.

Comtesse de Murinais, I 13

Comtesse Icy Hardegg, I I I.

Comtesse Riza du Parc, I I 4.

Comtesse Sophy Torby, 114.

Conrad F. Meyer, 46, rog.

Conserving moisture, 25.

Constance, 46.

Contents, table of, 2.

Cooper, Rev. A. E., roo.

Coquette des Alpes, I 1 \%

Coquette des Blanches, I I I.

Coquette de Lyon, i 14.

Corallina, I 14 .

Corinna, I 14 .

Cornelia Cook, I 14.

Coronation (H.P.), 46 .

Countess Clanwilliam, 46.

Countess of Derby, i i I.

Countess of Gosford, I I I.

Countess of Shaftesbury, III. 


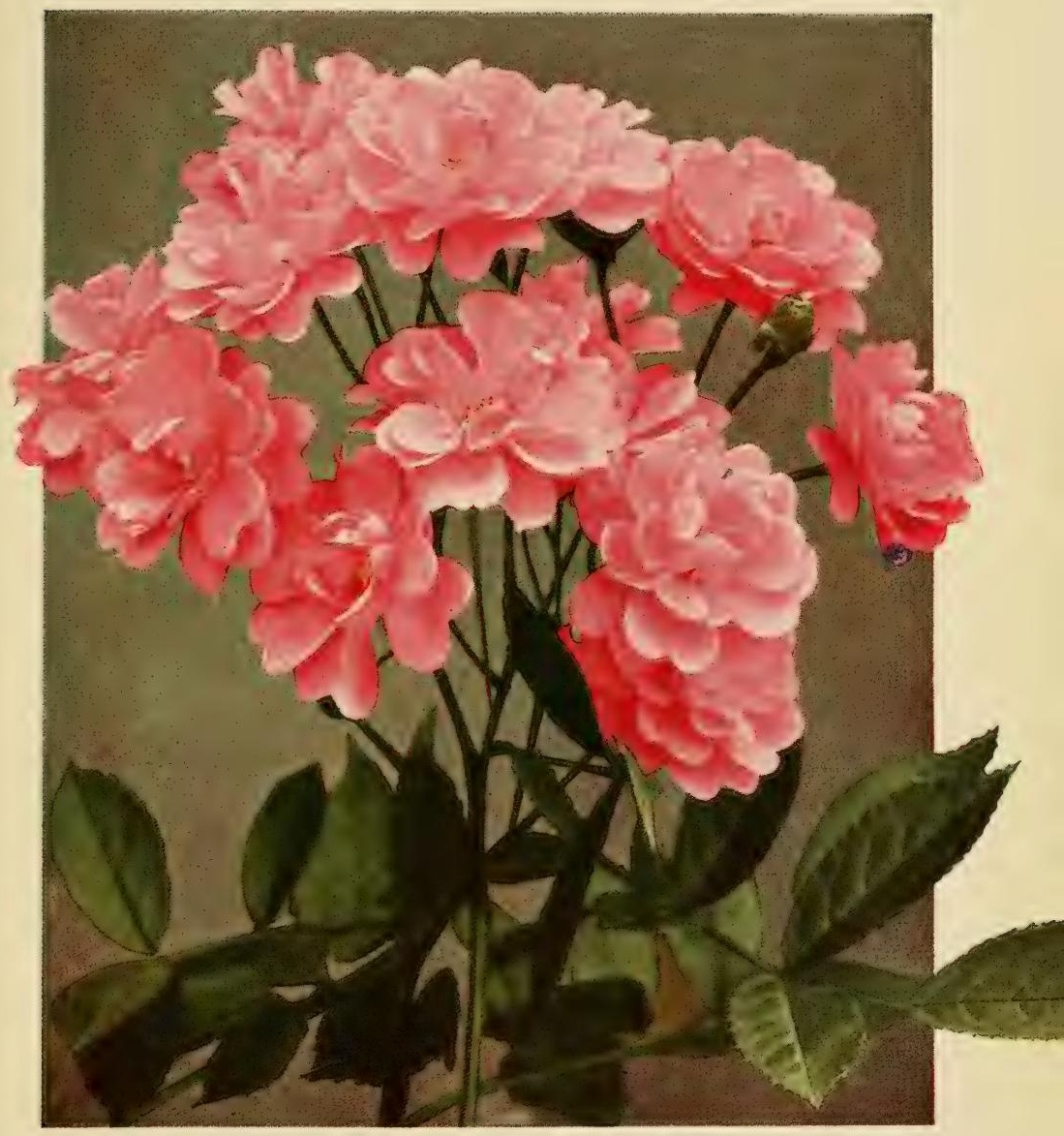

PINK BABY RAMBLER, or BABY DOROTHY, is a good representative of the Baby Rambler family, now available in an almost endless variety of colors, including white and all shades of pink and red.

This is the dwarf-growing Polyantha Rose so popular now for edging and also for bedding. It is recommended for use in place of geraniums, because it is so hardy that it does not need to be replanted yearly. 
Crested Moss, 47.

Crimson Globe, I 13.

Crimson Rambler, I08, I 5 .

Cumberland Belle, I is .

Currey, J. A., 77.

Daily Mail (Mme.

Edouard Herriot), 53.

Damascena, 108.

David Pradel, II4.

Daybreak, II 5 .

Dean Hole, Io, I Ir.

Debutante, II 5 .

Defiance, III.

De la Grifferai, 108.

Devoniensis, 47.

Dr. Grill, II 4 .

Distance apart for roses, I I.

Dr. J. Campbell HaII, I I I.

Dr. O'Donel Brown, II I.

Dr. W. Van Fleet, 47.

Dr. W. Van Fleet, White, I I 5 .

Dorothy Dennison, I06, I 5 .

Dorothy Page Roberts, I I I.

Dorothy Perkins, 47, I 06, I 08.

Dorothy Perkins, Red, I 06.

Dorothy Perkins, White, 47.

Douglas, I 10.

Drainage, I0-I 4 .

Duchesse de Brabant. 47.

Duchess of Albany, I I I.

Duchess of Sutherland, I I I.

Duchess of Wellington, 47.

Duchess of Westminster, I I I .

Dundee Rambler, 108.

Dutch Beauty, Io6.

EarI of Warwick, i i I.

Ecæ, I09.

Ecarlate, 47.

Echo, II3.

Edgar M. Burnett, II I.

Edith Part, III.

Edward Mawlev, I I I.

Egan, W. C., 26, 85 .

Ellen Poulsen, 47.

Eliot, Charles W., 9r.

Elizabeth Barnes, III.

Empress of China, I4.

Enchantress, II 4 .

Erna Teschendorff, 47.

Ethel Malcolm, I I I.

Etoile de France, 48.

Etoile de Lyon, 48.

Etoile de Mai, I 13 .

Eugene Boullet, I I I.

Eugene de Savoi, II3.

Eugene Furst, III.

Euphrosine, Io6.

Evangeline, I 15.
Evergreen Gem, I15.

Excelsa, 48.

Expert opinions, 77-91.

Farquhar, II 5 .

F. E. Coulthwaite, Ix $\mathrm{r}$.

Felicite et Perpetue, 108.

Fertilizers of all kinds, 16 .

Florence Forrester, I I I.

Florence Pemberton, 48.

Flower of Fairfield, i i 5 .

Formal garden, illustrated, 13.

Four seasons, 108.

Francois Levet, I I I.

Francis Scott Key, I I I.

Frau Berta Guertler, I 5 .

Frau Karl Druschki, 48.

Frau Lila Rautenstraugh, I I I.

F. R. Patzer, II I.

Fr. von Marschali, Ir 4 .

Fungoid troubles, 7 .

Gainsborough, III.

Gallica, 108.

Gallicæ, ro8.

G. Amedee Hammond, I I I .

Gardenia, 48.

Geisha, II 5 .

GeneraI Jacqueminot, 48 .

General MacArthur, 48.

General R. E. Lee, II 4 .

General-Superior Arnold-

Janssen, 48.

George Arends, I I I.

George C. Waud, in I.

George Dickson, 48.

George Elger, i I3.

Giant of Battles, I I I.

Giant Tree Rose, illustration of, 98 .

Gloire de Chedane Guinoisseau, 49.

Gloire de Dijon, 26.

Gloire de Margottin, II I.

Gloire Lyonnaise, 49.

Glory of Mosses, 49.

Gloire de Paris, I 06.

Glory of Paris, III.

G. Nabonnand, 114 .

Goldfinch, II3.

Golden Gate, i I 4.

Golden Rambler (see Alister Stella Gray)

Golden rules, 29.

Gorgeous, I I I .

Grace Molyneux, III.

Grafted roses, 36.

Grandiflora, 108.

Gravereaux, M. Jules, 24.

Green-fly, Aphis or, How to destroy, 6,30 .

Green Rose, 106.

Gruss an Aachen, 49.

Gruss an Teplitz, 49.

Gruss an Teplitz, Climbing, 49 .

Gustav Grunerwald, II I.
Hadley, I 1 I.

Hansa, II 4 .

Harisonii, I09.

Harison's Yellow, 49.

Harry Kirk, 49.

Hector MacKenzie, III.

Heeling-in roses, 19.

Heinrich Munch, III.

Helen Good, 49.

Helen Gould, i I r.

H. E. Richardson, III.

Henri Martin, 49.

Henry M. Stanley, i 44 .

Hermosa, 49.

Hiawatha, 49 .

Hibernica, Iog.

Hoosier Beauty, 50.

Huey, Dr. Robert, 82.

Hugh Dickson, 50.

Hugonis, 109.

Hugo Roller, 50.

H. V: Machin, i I I.

Hybridizing, A few words about, 104 .

Ideal, I I I.

Indica, 108.

Indicæ, 108 .

Indica odorata, 108.

Indica sanguinea, 108.

Insect enemies, 30 .

Involuta, 109.

Iona Herdman, I II.

Irish Beauty, II I.

Irish Elegance, 50.

Irish Fireflame, II I.

Isabella Sprunt, I 14 .

Ivory, I I 4 .

J. B. Varonne, II4.

James Coey, III.

Janet, III.

J. B. Clark, so.

Jeannette HeIler, г 06.

Jersey Beauty, I09, I I 5 .

John Hopper, I I I.

John Keynes, I I I.

Jonkheer J. L. Mock, 50.

Joseph Hill, so.

Josephine, I I I.

Juanita, I I 5 .

Jubilee, I I r.

Juliet, 50 .

Kaiserin Augusta Victoria, 50.

Kaiserin Augusta Victoria, Climbing, I 15 .

Katherine Zeimet, I I3.

Killarneys, 50, Io6.

Killarney Brilliant, 50.

Killarney Queen, III.

Killarney, Striped, ro6.

Killarney, Climbing, I 5 .

Killarney, White, III.

Killarney, White, Climbing, I I 5 .

King George V., I I r.

Königin Carola, I I I.

Königin Wilhelmina, I I4. 
Labeling, 22, 23.

Labels, copper, 22; zinc; celluloid, stake, gardenclub, Mann, 23; Simplex, 24 .

Lady Alice Stanley, 50.

Lady Duncan, II4.

Lady Gay, I14.

Lady Godiva, 106.

Lady Greenall, 1 I I.

Lady Helen Stewart, I I I.

Lady Hillingdon, 50.

Lady Mary Ward, 50.

Lady Moyra Beauclerc, III.

Lady Penzance, 50.

Lady Pirrie, I II.

Lady Plymouth, II4.

Lady Roberts, II 4 .

Lady Ursula, I 1 I.

La France, 50, 106.

La France, Climbing, I 5.

La France, Red (Duchess of Albany), I06.

La France, Striped, 106.

La France, White (Augustine Guinoisseau), 106.

Lamarque, II 5 .

La Reine, I I 1 .

La Reine des Neige, 106.

La Roseire, 106.

La Tosca, 50.

Laurent Carle, 52.

Lævigata, I09.

Lævigatæ, I09.

Lena, I14.

Leonie Lambert, 1 I 1 .

Leonie Lamesch, 52.

Leopoldine d'Orleans, 108.

Leslie Holland, i I I .

Letty Coles, I 14 .

Liberty, I I I.

Lieutenant Chaure, III.

Longwood, I 14.

Louise C. Breslau, 52.

Louise Lilia, II 1 .

Louise Walter, 52.

Lucida, rog.

Lucullus, 1 io.

Lutea, I09.

Luteæ, 109.

Lyon Rose, 52.

Macartney, rog.

McFarland, J. Horace, $92,105$.

Macrantha, 109.

Macrophylla, 109.

Mme. Abel Chatenay, I I I.

Mme. Alfred Carriere, 52 .

Mme. Angel Vayssett, 106.

Mme. Antoine Mari, I14.

Mme. Bernier d'Árnex, II 1 .

Mme. Camille, 52.

Mme. Caroline Kuster, I 14.

Mme.C. P. Strassheim, I I 4 .

Mme. Caroline Testout, 52.
Mme. Caroline Testout, Climbing, 115 .

Mme. Chas. Frederick Worth, II4.

Mme. Charles Lutaud, 52.

Mme. Charles Wood, in .

Mme. Colette Martinet, III.

Mme. Derepas-Matrat, I 06 , I 14.

Mme. de Vatrey, I 4.

Mme. de Watteville, I 14.

Mme. Driout, I 15 .

Mme. Edmond Rostand, 52.

Mme. Edouard Herriot (Daily Mail Rose), 53 .

Mme. Elie Lambert, I 4.

Mme. Eugenie Boullet, II 1 .

Mme. Eugene Marlitt, 53.

Mme. Felix Faure, I I I.

Mme. F. Kruger, I 14.

Mme. Georges Bruant, I09.

Mme. Hoste, I 14.

Mme. Jean Dupuy, I 14.

Mme. Jenny Guillemot, 111.

Mme. Jos. Schwartz, I I 4 .

Mme. Jules Bouché, I I I.

Mme. Jules Gouchault, I 14 .

Mme. Jules Gravereaux, I I 5 .

Mme. Jules Grolez, 53.

Mme. J. W. Budde, I 1 I.

Mme. Lambard, I I4.

Mme. Leon Pain, 53.

Mme. Margottin, I I4.

Mme. Masson, i I I.

Mme. Maurice de Luze, I 13.

Mme. Melanic Soupert, 53.

Mme. Norbert Levavasseur (Crimson Baby Rambler), I 13.

Mme. Olga, i 14.

Mme. Phillip Rivoire, I 13.

Mme. P. Euler, II3.

Mme. Plantier, 75 .

Mme. Ravary, 53.

Mme. Rene Gerard, I I 4.

Mme. Segond Weber, 53 .

Mme. Vermorel, 114.

Mme. Wagram, I I 5 .

Mme. Welche, I14.

MIle. Augustine Guinoisseau, 113 .

MIle. Helena Gambier, 113.

MIle. J. Phillips, I 14.

MIle. Louise Crete, I I I .

MIle, Marie Mascurand, 113.

Mabel Drew, 113.

Madison, 53 .

Maddalena Scalarandis, I 10 .
Magna Charta, 53.

Magnafrano, I13.

Magnifica, II4.

Magnolia Rose, 106.

Maiden's Blush, 108.

Mama Looymans, I13.

Maman Cochet, Pink, 53.

Maman Cochet, Pink, Climbing, 53.

Maman Cochet, White, 56.

Maman Cochet, White, Climbing, I 15 .

Maman Cochet, Yellow, Io6.

Maman Levavasseur (Baby Dorothy), 106, I 13.

Manda's Triumph, I 4.

Manetti, 108.

Manetti roses for grafting, 36.

Manure, liquid, When to apply, 16.

Map of U. S. A., I 8.

Marcella, i 13 .

Marchioness of Lorne, I I I.

Marechal Niel, 56 .

Margaret Dickson, I I I .

Margaret Dickson Hamill, 56.

Marie Guillot, 56 .

Marie Lambert, I 14.

Marie Leonidas, 108.

Marie Pavie, 56.

Marie Van Houtte, 56.

Marion Dingee, 114.

Mark Twain, I 13.

Marquise de Querhoent, I 3 .

Marquise de Sinety, 56.

Marshall P. Wilder, I I $\mathbf{x}$.

Mary, Countess of IIchester, 56.

Mary Lovett, 56.

Mawley, Edward, 29.

Max Hesdorffer, 113.

May Miller, i 13.

May Queen, 56.

Medea, I I 4.

Meteor, I1 3 .

Meteor, Climbing, I 15.

Mice, How to guard against, 27.

Microphylla, 109.

Microphyllæ, I 09.

Mignon, I06, I 13.

Mignonette, I 14 .

Milady, I 13 .

Mildew, How to remedy, 6.

Milis, Rev. E. M., 80-97.

Miniature, I I 4.

Minnehaha, I I 5 .

Minutifolia 109.

Miss Alice de Rothschild, 57.

Miss Cynthia Forde, 57.

Miss Messman, 115 .

Moisture, How to conserve, 25. 
Moles, How to guard against, 27.

Molly Sharman-Crawford, 57.

Moschata, 108.

Moschata alba, 108.

Moscosa, 108.

Mosella, I 14 .

Mosella, Climbing, I 5 .

Moss, I08.

Mousseline, 113.

Multiflora simplex, 108 .

Multifoliæ, 109.

Mrs. Aaron Ward, 57.

Mrs. A. E. Coxhead, I13.

Mrs. Ambrose Riccardo, II3.

Mrs. Amy Hammond, I 13.

Mrs. Andrew Carnegie, II3.

Mrs. Archie Gray, II3.

Mrs. A. R. Waddell, 57.

Mrs. B. R. Cant, 57.

Mrs. Bertram T. Walker,

Mrs. Campbell Hall, I 14.

Mrs. Chas. E. Pearson, II3.

Mrs. Chas. Hunter, II 3.

Mrs. Charles RusselI, II3.

Mrs. Conway Jones, I13.

Mrs. Cornwallis West, II3.

Mrs. David Jardine, I13.

Mrs. David McKee, II 3 .

Mrs. Edward Powell, I I3.

Mrs. Forde, I1 3 .

Mrs. Foley Hobbs, I 14.

Mrs. F. W. Vanderbilt, II3.

Mrs. George Gordon, I 13.

Mrs. George Norwood, II3.

Mrs. George Shawyer, I 13.

Mrs. Harold Brocklebank, 113.

Mrs. Harvey Thomas, II3.

Mrs. H. Hawksworth, I 14.

Mrs. Herbert Stevens, 57.

Mrs. Hubert Taylor, in 4 .

Mrs. Hugh Dickson, I 13 .

Mrs. John Laing, 57.

Mrs. J. H. Welsh, II3.

Mrs. MacKellar, I 13 .

Mrs. Maynard Sinton, II3.

Mrs. M. H. Walsh, II 5 .

Mrs. Moorefield Storey, II 3 .

Mrs. Myles Kennedy, I 14 .

Mrs. O. G. Orpen, I 10.

Mrs. R. D. McClure, i13.

Mrs. Richard Draper, I13.

Mrs. R. G. SharmanCrawford, III.

Mrs. Robert Garrett, II3.

Mrs. Robert Peary, II 5 .

Mrs. Sam Ross, I I3.
Mrs. S. T. Wright, I14.

Mrs. Taft, I 14 .

Mrs. Theo. Roosevelt, Ix3.

Mrs. T. Hillas, I 13 .

Mrs. W. Christie Miller, 57.

Mrs. W. H. Cutbush, Io6, I 14 .

Mrs. Wemyss Quin, I I3.

Mrs. W. J. Grant, 106.

Mulch, dust 6; grass, leaves, sawdust, peatmoss, 7,25 .

Mulching, 25.

Multiflora roses for grafting, 36.

Municipal rose-gardens, 95.

Muriel Dickson, 57.

Muriel Grahame, I i 4 .

Muscosa, 108.

My Maryland, 50.

My Maryland, Climbing, I 15 .

Natalie Bottner, 113.

Neervelt, I13.

Nerissa, I1 3 .

New Century, 59.

Nita Weldon, I 14 .

Noisettes, ro8.

Nova Zembla, I 14.

Oakmont, I I r.

Old-Gold, i 13.

Oliva, 113 .

Ophelia, 59.

Orleans, 59.

Orpet, Mr., 26.

Panama, Ir3.

Papa Gontier, 114.

Parker, G. A., 91, 95.

Paula Clegg, III.

Paul Neyron, 59.

Paul's Carmine Pillar, I1 5 .

Pearl Queen, I 15.

Peerless, I I3.

Pemberton, Rev. J. H., I05.

Perle d'Or, I I 4.

Perle des Jardins, 59.

Perle des Jardins, Climbing, I 15.

Perle des Jaunes, II 4.

Pernet's Triumph, I13.

Persian Yellow, 59, 109.

Pharisaer, II 3 .

Philadelphia Rambler, 59.

Pillar of Gold, I 15.

Pimpinellifoliæ, 109.

Pink Daily, i $о$ o.

Pink Memorial, Db, (Universal Favorite), II 5 .

Pissardii, 108.

Plant-food, 7.

Plant roses, When to, 17.

Plant roses, Depth to, 20.
Planting roses, General rules on, 20.

Platting, 24.

Pomifera, 109.

Powdery mildew, 30.

President Vignet, I13.

Prima Donna (Mme. P. Euler), 106, 113.

Prince Camille de Rohan, 59, 106.

Prince Charles d'Arenburg, I 13.

Prince of BuIgaria, I13.

Princess Adelaide, 59.

Princess Bonnie, II3.

Princess de Sagan, I14.

Princess Hohenzollern, I 14.

Prof. C. S. Sargent, I 15.

Protection for winter, 2629.

Protecting tree roses, 29.

Provence, 108.

Prune, When to, 6, 7.

Pruning, information, 3135 .

Pruning-shears, 35.

Psyche, II5.

Pyle, Robert, roo.

Queen Beatrice, II3.

Queen Mary, II3.

Queen OIga of Greece, 114.

Queen's Scarlet, 59.

Queen, The, 106, 114 .

Radiance, 60.

Rainbow, I14.

Rambler, Crimson, II 5.

Ramblers, I 5 .

Rayon d'Or, 60.

Red-Letter Day, II3.

Red Rose Church at Manheim, roo.

Regina Badet, I I 4 .

Reine Carola de Saxe, I 13.

Reine Marguerite d'Italie, I 13.

Reine Marie Henriette, I I 5 .

Rembrandt, I I 1 .

Rene Robbins, I13.

Renee Wilmart Urban, I 13.

Repens alba, I 14 .

Reve d'Or, II 5 .

Rhea Reid, 60.

Richmond, I I j.

Robert Craig, I 15 .

Roberts, Rev. F. Page, 14.

Roger Lambelin, 60.

Roosevelt, Ex-President Theodore, 10.

Rose-beads, ro 1 .

Rose-beetle, Spray for, 6.

Rose-bug, 30.

Rose-chafer, 30.

Rose-garden, The amateur's, 3.

Rose-gardens, Famous, 27, 97, 98-100. 
Rose-gardens, Municipal, 95-97.

Rose hedges, 74 .

Rose nicotine for aphis, 6 , 30.

Rose perfume, 102.

Rose progress, 93, 97.

Rose-slug, Spray for, 6, 30.

Rose test-gardens, 93.

Roses, Appropriate uses for, $41,42$.

Roses, Attar of, ror.

Roses, Cemetery, 75.

Roses, Dependable varieties of, 43-62.

Roses, Establishing ideals, 5.

Roses, Forcing, 76 .

Roses, How to arrange, 5 .

Roses, Various uses of, 64-77.

Roses, Where to plant, 9.

Rose d'Evian, II4.

Roseraie de L'Hay, 60.

Roseraie de L'Hay Rosegarden, Partial description of, 98-roo.

Roseraie Parfum de L' Hay, II4.

Rubiginosa, 109.

Rubrifolia, 108.

Ruby Queen, II 5 .

Rugosa, 109.

Rugosa alba, 6o, ro9.

Rugosa rubra, 60, 109.

Safrano, 60.

Salet, I 13.

Santa Rosa, i 10.

Scissors, Pruning, 35.

Sea-bird, 113.

Selecting the right roses, 37-41.

Semperflorens, 108

Sempervirens, 108.

Sericea, 109.

Sericeæ, rog.

Setigera, 108.

Shears, Pruning, 35.

Shower of Gold, i 5 .

Silver Moon, 60 .

Simplicifoliæ, rog.

Sinica, rog.

Sir Thomas I ipton, 61 .

Smothering roses, About, 27.

Soap, Whale-oil, 30.
Sodenia, 115.

Soils, 14 .

Soleil d'Or, 6r.

Solfaterre, I1 5 .

South Orange Perfection, I I 5 .

Souv. de Catherine Guillot, I I4.

Souv́. de E. Guillard, Ir3.

Souv, de Gustav Prat, 6I.

Souv. de la Malmaison, 6r.

Souv. de Pierre Leperdrieux, II 4 .

Souv. de P. Notting, 6r.

Souv. du President Carnot, II3.

Souv. de S. A. Prince, гоб.

Souv. of Wootton, I13.

Souv. of Wootton, Climbing, 115.

Spectacular, I 13.

Spinosissima, 10?.

Spinosissimæ, 109

Spray, When to, 6, 7 .

Standard roses, $13,73$.

Staking, 22.

Stylosa, 108.

Stylosæ, 108.

Sulphurea, ro9, 1 I 4.

Sunburst, 6r.

Sunrise, 6r.

Sunset, II 4 .

Synonymous roses, 106.

Synstylæ, 108.

Sweetbriar, 6I.

Sweetheart, 106, I1 5 .

Taft Rose, 6r.

Tausendschön, 6r.

Tea-scented, I08.

Temperature in different latitudes, 18.

Temple of Love, 99.

Test-gardens, 93 .

Thalia, i 5 .

Thomas, George C., Jr., 25.

Thousand Beauties, I06.

Tip-Top, I I 4 .

Tomentosa, 109.

Tom Wood, I I I.

Tree roots, Danger from, 9.

Tree roses, 13, 73 .

Trier, II5.

Triomphe d'Orleans, I 14.
UIrich Brunner, 62.

Universal Favorite, 115.

Van Fleet, Dr. W., 83.

Varieties, Number of, 37.

Veluwezoom, II3.

Vick's Caprice, III.

Victor Verdier, 1 I I.

Villosa, rog.

Virginia R. Coxe, r o6, i I3.

Viridiflora, I Io.

Viscountess Enfreld, I I3.

Walter Speed, 113.

Waltham's Scarlet, I 13.

Ward, Admiral Aaron, 8r.

War of the Roses, York and Lancaster Rose, associated with the, 63 .

Wartburg, II 5 .

W. C. Egan, I1 5 .

Weeds, How to keep down, 25.

W. E. Lippiatt, 113.

Wellesley, II3.

West Grove, I 13.

White American Beauty, (Frau Karl Druschki), ro6.

White Killarney, 62.

White Killarney, Climbing, 115 .

White Maman Cochet, 56 .

White Maman Cochet, Climbing, i 5 .

White Soupert, I I 4.

Wichmoss, 62.

Wichuraiana, 62, 108.

Wichuraiana variegata, i I 5 .

Wm. Allen Richardson, 62.

Wm. Cooper, II 3 .

Wm. R. Smith, 62.

William Shean, 62 .

Willowmere, 62.

Winnie Davis, I 13 .

Winter Gem, I I 4 .

Winter-protection, 27-29

Winter-protection, When to remove, 27.

Wirth, Theodore, 29, 79 .

Xanthina, 109.

Yellow Soupert, 114

York and Lancaster, 62, I08.

Yvonne Rabier, I14. 







\section{LIBRARY OF CONGRESS ||||||||||||||||||||||||||||||||||||||||||

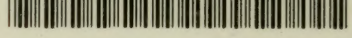 \\ 00009199032}

